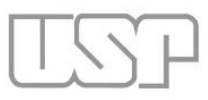

TIAGO ALEXANDRE SILVA ZENARO DO PRADO

REURBANIZAÇÃO DA FAVELA DO REAL PARQUE EM SÃO PAULO: UM OLHAR SOBRE IMPACTOS E POSSIBILIDADES DO PROCESSO DE REESTRUTURAÇÃO URBANA

SÃO PAULO 


\section{Reurbanização da favela do Real Parque em São Paulo: um olhar sobre impactos e possibilidades do processo de reestruturação urbana}

Tiago Alexandre Silva Zenaro Do Prado

Reurbanização da favela do Real Parque em São Paulo: um olhar sobre impactos e possibilidades do processo de reestruturação urbana

Dissertação apresentada ao Programa de Pós-Graduação Ambiente, Saúde e Sustentabilidade, da Faculdade de Saúde Pública, da Universidade de São Paulo, para a obtenção do título de Mestre em Ciências.

Orientadora: Prof. ${ }^{\text {a }}$ Dr. ${ }^{a}$ Gabriela Marques Di Giulio

\section{SÃO PAULO}

2017

VERSÃO REVISADA 
É expressamente proibida a comercialização deste documento, tanto na sua forma impressa como eletrônica. Sua reprodução, total ou parcial, é permitida exclusivamente para fins acadêmicos e científicos, desde que na reprodução figure a identificação do autor, título, instituição e ano da dissertação.

\section{Catalogação da Publicação}

Serviço de Documentação XXXX

Faculdade de Saúde Pública da Universidade de São Paulo

Prado, Tiago Alexandre Silva Zenaro do

Reurbanização da favela do Real Parque em São Paulo: uma análise sobre possibilidades e impactos da reestruturação urbana para a localidade. Prof. ${ }^{a}$ Dr. ${ }^{a}$ Gabriela Marques Di Giulio (orientadora) - São Paulo - 2017.

$\mathrm{N}^{0}$ fls. 122 f.: il.

Dissertação (Mestrado) - Universidade de São Paulo, 2017 
PRADO, Tiago Alexandre Silva Zenaro do. Reurbanização da favela do Real Parque em São Paulo: um olhar sobre impactos e possibilidades do processo de reestruturação urbana - Faculdade de Saúde Pública da Universidade de São Paulo, São Paulo, 2017. 


\section{FOLHA DE APROVAC̃̃̃ (DISSERTACÃO)}



Dedico este trabalho a todos aqueles que sempre acreditaram em mim, que nunca me abandonaram, nem viraram as costas nos momentos mais difíceis. Graças a vocês eu segui e sigo em frente e essa conquista não é só minha, mas de todos nós. Muito obrigado. 


\section{AGRADECIMENTOS}

Agradeço a todos que, de qualquer forma, contribuíram para esta pesquisa, acreditando no meu potencial e investindo em mim.

Agradeço à Faculdade de Saúde Pública pela oportunidade que me foi dada, aos professores pelas sugestões e contribuições durante as disciplinas e nas conversas informais e aos funcionários por todo auxílio ao longo desta jornada.

Um agradecimento especial à minha orientadora, $\operatorname{Prof}^{\mathrm{a}}$. $\operatorname{Dr}^{\mathrm{a}}$. Gabriela Marques Di Giulio, pela importância e competência em sua orientação, trazendo para o diálogo outras áreas de conhecimento, enriquecendo a pesquisa e tornando-a sempre mais desafiadora. Você possibilitou a realização deste trabalho, obrigado pela contribuição, amizade e paciência. Agradeço também à Prof ${ }^{\mathrm{a}}$. Dr ${ }^{\mathrm{a}}$. Maria da Penha Vasconcellos, por ter me recebido quando cheguei e por ter me ajudado nos primeiros passos na FSP.

Agradeço aos membros da banca examinadora de qualificação do projeto, Prof. Dr. Eduardo José Marandola Junior e $\operatorname{Prof}^{\mathrm{a}}$. Dr ${ }^{\mathrm{a}}$. Helena Ribeiro, pelas contribuições e apontamentos necessários, colaborando para a profundidade desta dissertação, sendo fundamentais para a sua conclusão. Agradeço mais uma vez aos professores pela participação na banca examinadora da defesa, juntamente com o Prof. Dr. Eduardo Soares de Macedo.

À Mariana Silveira, por estar presente desde o princípio, trazendo contribuições para a pesquisa, dando dicas, incentivando e me fazendo compreender por onde traçar os meus caminhos, trazendo palavras positivas e nunca permitindo que eu perdesse o foco.

Agradeço aos moradores do Real Parque que, de forma tão carinhosa, me receberam todas às vezes durante a realização da pesquisa, foram solícitos em todos os pedidos e contribuíram de forma singular para a realização do trabalho. Em especial agradeço à Dona Inerci (Nell), pois sem ela este trabalho não teria sido realizado, você foi essencial para o desenvolvimento desta pesquisa. À Layne e ao Victor, pelo tempo comigo, por me ajudarem a organizar reuniões, contatar moradores, organizar a logística e doarem seu tempo para que fosse possível esta etapa. Sem vocês não seria possível a pesquisa. Agradeço aos outros moradores que também contribuíram com as pesquisas e dispuseram tempo e paciência, pensando sempre em melhorar sua comunidade. Muito obrigado. 
Aos meus amigos que me apoiaram e sempre se preocuparam com o andamento da pesquisa e entenderam a ausência nos finais de semana e feriados, tornando a vida social mais apertada mas sempre com palavras de incentivo e carinho.

Aos queridos, Patrícia, Tom, Rogério, Uelinton e Leandro por sempre acreditarem em mim, trazendo palavras de incentivo e confiando no meu trabalho e potencial.

À PHS-11, por sempre acreditar em mim e fazendo com que todo o processo fosse mais leve e proveitoso.

À Flavia, por sempre me apoiar, trazendo palavras de incentivo e colaborando em tudo.

À minha mãe, Mara, e ao meu avô, José, pela participação neste tempo de curso, sempre com palavras de carinho e torcida, assim como a toda família pelo carinho.

E a Deus, por permitir que eu esteja nos melhores lugares, com as melhores pessoas e sempre me dando a capacidade de superação. 


\section{RESUMO}

PRADO, Tiago Alexandre Silva Zenaro do. Reurbanização da favela do Real Parque em São Paulo: um olhar sobre impactos e possibilidades do processo de reestruturação urbana. 2017. 115 F. Dissertação (Mestrado) - Faculdade de Saúde Pública, Universidade de São Paulo, São Paulo, 2017.

No Brasil a expansão urbana, como um componente fundamental das mudanças estruturais na sociedade brasileira, ocorreu de forma mais intensa na segunda metade do século XX, entre os anos de 1950 e 1970. O processo de urbanização, baseado na terra como mercadoria e acompanhado por uma ocupação desordenada, trouxe diversos problemas para boa parte das cidades brasileiras, com ocupações em áreas de rios e encostas, lançamentos de resíduos em cursos d'água e terrenos vazios, saneamento básico insuficiente, habitações insalubres, trânsito, ruído e poluição. São Paulo, a cidade mais populosa do país e o principal centro financeiro, corporativo e mercantil da América do Sul, é representativa desse processo. Estudos focados na urbanização da cidade revelam que a dinâmica de expansão da metrópole tem provocado um processo de concentração de população de baixa renda em áreas periféricas, mas também em localidades que concentram bolsões de pobreza e abrigam populações de baixa renda, com processos de ocupação por atividades irregulares, como invasões, favelas e loteamentos clandestinos. Exemplo de uma dessas áreas é a antiga favela do Real Parque, situada no bairro do Real Parque, um dos cinco bairros que compõem o distrito do Morumbi, na subprefeitura do Butantã, e considerada uma área de risco e que passou recentemente por um processo de reurbanização. Pelas suas especificidades, esse território é um estudo de caso ilustrativo para pensar os contrastes da megacidade, os impactos da urbanidade (ou da sua falta), a conformação de áreas de ocupação irregular e as relações estabelecidas pelos seus moradores e os possíveis delineamentos de processos de reurbanização. Neste sentido, a presente dissertação apresenta e discute resultados de uma pesquisa que teve como objetivo geral compreender, na perspectiva dos moradores, as potencialidades e limitações do processo de reurbanização nesta localidade, que teve início em 2008 e seguiu até 2016, com a entrega dos últimos condomínios. Como objetivos específicos, buscou-se investigar as características dessa localidade, particularmente antes do início da reurbanização; identificar percepções dos moradores sobre o local onde vivem e condições de vulnerabilidades; e compreender, a partir das suas narrativas, como as mudanças relacionadas ao novo empreendimento têm impactado o cotidiano da comunidade. Por meio de pesquisa documental e pesquisa de campo, o estudo partiu da hipótese de que enquanto os riscos geológicos foram minimizados e/ou se tornaram inexistentes, outros problemas e condições de vulnerabilidade passaram a ganhar maior visibilidade e projeção para os moradores.

Palavras-chave: Urbanização, Real Parque, vulnerabilidade, identidade, qualidade de vida. 


\section{ABSTRACT}

PRADO, Tiago Alexandre Silva Zenaro do. Reurbanization of the favela Real Parque, São Paulo: a look at impacts and possibilities of urban restructuring process. 2017. $115 \mathrm{~F}$. Dissertação (Mestrado) - Faculdade de Saúde Pública, Universidade de São Paulo, São Paulo, 2017.

In Brazil, urban expansion, as a fundamental component of structural changes in Brazilian society, occurred more strongly in the second half of the twentieth century, between the 1950s and 1970s. The urbanization process, based on land as a commodity, and accompanied by a disorderly occupation brought diverse problems for most Brazilian cities, with occupations in rivers and slopes, waste streams in empty water and land, insufficient basic sanitation, unhealthy housing, traffic, noise and pollution. São Paulo, the most populous city in the country and the main financial, corporate and mercantile center of South America, is representative of this process. Studies focused on the urbanization of the city reveal that the dynamics of metropolis' expansion has provoked a process of concentration of low income population in peripheral areas, but also in localities that concentrate pockets of poverty and shelter low income populations, with processes of occupation by irregular activities such as invasions, favelas and clandestine settlements. An example of one of these areas is the former Real Parque favela, located in the neighborhood of Real Parque - one of the five neighborhoods that compose the Morumbi district, in the region of Butantã -, and considered a risk area, which has recently undergone a process of reurbanization. For its specificities, this territory is an illustrative case study to think about the contrasts of the megacity, the impacts of urbanity (or its lack), the conformation of areas of irregular occupation and the relations established by its residents, and possible delineations of processes of reurbanization. This dissertation presents and discusses results of a study that seeks to understand, from the perspective of the residents, the potentialities and limitations of the reurbanization process in this locality, which initiated in 2008 and continued until 2016, with the delivery of recent condominiums. This study also seeks: (i) to investigate the characteristics of this locality, particularly before the beginning of the reurbanization; (ii) to identify residents' perceptions of this place and conditions of vulnerability; (iii) to understand, from their narratives, how the changes related to the new enterprise have affected the daily life of the community. Through documentary research and field research, the study is based on the hypothesis that while geological risks were minimized and/or became non-existent, other problems and conditions of vulnerability started to gain greater visibility and projection for the residents.

Keywords: Urbanization, Real Parque, vulnerability, identity, quality of life. 


\section{LISTA DE SIGLAS E ABREVIATURAS}

BNH - Banco Nacional de Habitação

CEM - Centro de Estudos da Metrópole

CNPJ - Cadastro Nacional de Pessoas Jurídicas

COHAB - Companhia Metropolitana de Habitação

EIA - Estudo de Impacto Ambiental

EMPLASA - Empresa Paulista de Planejamento Metropolitano

ESF - Estratégia Saúde da Família

FAPESP - Fundação de Amparo à Pesquisa do Estado de São Paulo

FAU - Faculdade de Arquitetura e Urbanismo

FSP/USP - Faculdade de Saúde Pública da Universidade de São Paulo

FUNDAP - Fundação do Desenvolvimento Administrativo

IBGE - Instituto Brasileiro de Geografia e Estatística

ICE - Instituto de Cidadania Empresarial

IEE/USP - Instituto de Energia e Ambiente da Universidade de São Paulo

INFOCIDADE - Endereço para consultas de dados sobre a Cidade de São Paulo

IPT - Instituto de Pesquisas Tecnológicas

ONG - Organização Não-Governamental

ONU - Organização das Nações Unidas

ONU-HABITAT - Programa das Nações Unidas para os Assentamentos Humanos

PNRS - Política Nacional de Resíduos Sólidos

PROVER - Programa de Urbanização e Verticalização de Favelas 
RIMA - Relatório de Impacto Ambiental

RMBS - Região Metropolitana da Baixada Santista

RMC - Região Metropolitana de Campinas

RMSP - Região Metropolitana de São Paulo

RMVP-LN - Região Metropolitana do Vale do Paraíba e Litoral Norte

SEHAB - Secretaria Municipal de Habitação

SEHAD - Secretaria Municipal de Habitação e Desenvolvimento Social

SPTRANS - São Paulo Transportes

UBS - Unidade Básica de Saúde

UPA - Unidade de Pronto Atendimento

ZEIS - Zonas Especiais de Interesse Social 


\section{LISTA DE IMAGENS}

Imagem 1: Foto antiga do bairro e do estádio do Morumbi na década de 1950

Imagem 2: Destaque da área na qual foi implementado o projeto de construção dos condomínios

Imagem 3: Mapa com os limites das glebas

Imagem 4: Imagem do projeto de substituição dos barracos existentes por conjuntos habitacionais, em um total de 1.135 apartamentos

Imagem 5: Mapeamento das instituições existentes na região 


\section{LISTA DE MAPAS}

Mapa 1: Mapa da área do Real Parque: 1952

Mapa 2: Histórico demográfico do Município de São Paulo - área urbanizada 1930-1949

Mapa 3: Histórico demográfico do Município de São Paulo - área urbanizada 1950-1962

Mapa 4: Histórico demográfico do Município de São Paulo - área urbanizada 1993-2002

Mapa 5: Localização do Real Parque, no distrito do Morumbi

Mapa 6: Localização do Real Parque 


\section{LISTA DE TABELAS}

Tabela 1: Situação habitacional em 2008

Tabela 2: Tempo de moradia

Tabela 3: Composição familiar

Tabela 4: Renda familiar

Tabela 5: Resultados da pesquisa conduzida pelo Projeto Casulo em 2004 sobre problemas socioeconômicos na localidade

Tabela 6: Reuniões com moradores da comunidade (três reuniões ao longo de 2015 e 2016)

Tabela 7: Entrevistas individuais (entrevistas realizadas ao longo de 2015 e 2016)

Tabela 8: Grupo focal misto (grupo focal misto realizado em 10 de Jul. 2016)

Tabela 9: Grupo focal de jovens (grupo focal de jovens realizado em 04 de Set. 2016) 


\section{SUMÁRIO}

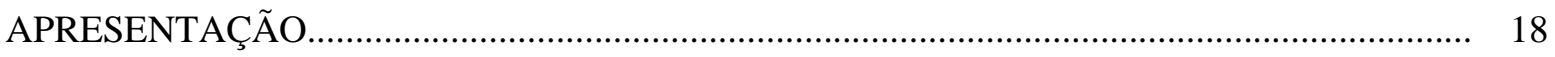

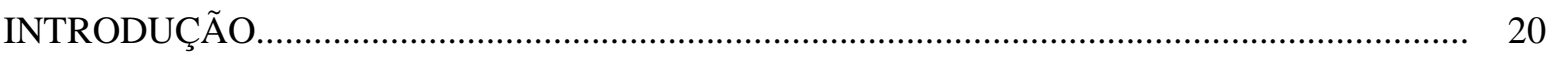

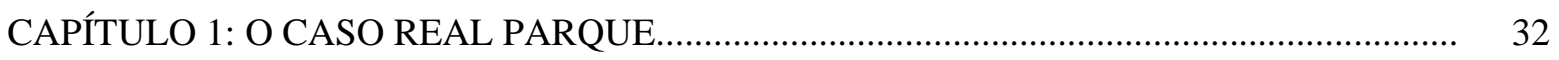

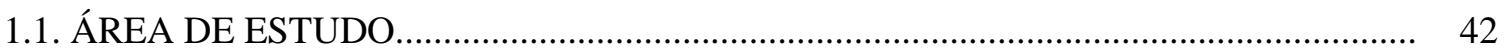

1.2. OS EFEITOS DO PROJETO DE REURBANIZAÇÃO................................................. 56

CAPÍTULO 2: ABORDAGEM METODOLÓGICA............................................................... 58

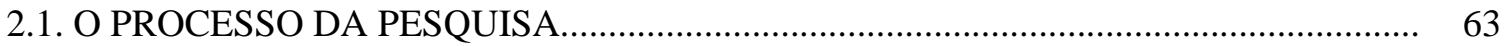

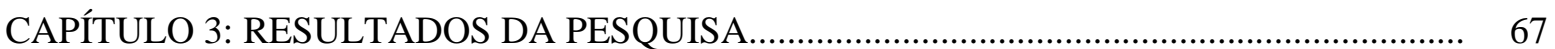

3.1. O ANTES E O DEPOIS - MUDANÇAS NAS CONDIÇÕES DE 67 VULNERABILIDADE.

3.2. LUGAR, PERTENCIMENTO E IDENTIDADE.

3.3. DEMANDAS E NECESSIDADES PARA MELHORAR A QUALIDADE DE VIDA 100 DOS MORADORES

CONSIDERAÇÕES FINAIS

REFERÊNCIAS BIBLIOGRÁFICAS.

109 


\section{APRESENTACẼO}

Escolhi como graduação a Geografia, pois sempre tive interesse em entender as dinâmicas de funcionamento do mundo, as interações sociais, as relações do homem com o meio ambiente e a produção do espaço. Algo que sempre me encantou na Geografia foi a possibilidade de ter uma visão mais ampla dos processos que conduzem o desenvolver da sociedade. No meu trabalho de conclusão de curso, optei pelo enfoque na área de Climatologia mesclado à Educação e meu tema da pesquisa foi a tendência ao aquecimento global antrópico, com uma análise de seis livros didáticos de Geografia do Ensino Fundamental.

Como Geógrafo, tenho buscado a interação dos diversos saberes e a interdisciplinaridade para compreender os aspectos reprodutores do espaço. Como destaca Eric Dardel: “A geografia não designa uma concepção indiferente ou isolada, ela só trata do que me importa ou do que me interessa no mais alto grau: minha inquietação, minha preocupação, meu bem-estar, meus projetos, minhas ligações. A realidade geográfica é, para o homem, então, o lugar onde ele está, os lugares da sua infância, o ambiente que atrai sua presença. Terras em que ele pisa ou onde ele trabalha, o horizonte do seu vale ou a sua rua, o seu bairro, seus deslocamentos cotidianos através da cidade" (DARDEL, 2011, p. 33).

Essa busca reflete também na minha formação acadêmica, na escolha do objeto de estudo desta dissertação e na minha carreira profissional como professor, buscando compreender as modificações advindas com o incremento da globalização e as mudanças nas estruturas dentro de uma cidade como São Paulo.

Antes de ingressar no mestrado, tive a oportunidade de realizar uma pósgraduação latu sensu no Instituto de Energia e Ambiente IEE/USP em Gestão ambiental e negócios no setor energético, visto a crescente necessidade pela busca de alternativas em sanar problemas ambientais relacionados à poluição e encontrar novas possibilidades de geração de energia limpa. O trabalho apresentado neste curso envolveu uma análise sobre o potencial de biogás não aproveitado na mesorregião do Sul da Bahia como instrumento de fomento à adequação à Política Nacional de Resíduos Sólidos (PNRS). O tema me levou a questionar o quanto a sociedade não se 
preocupa (ou se preocupa pouco) em evitar algumas situações, mas sempre busca alternativas para melhorar o que foi comprometido pela falta de planejamento, no caso, o destino do resíduo gerado e um possível reaproveitamento em outros setores.

Com o intuito de continuar a ampliar minhas áreas de conhecimento e a compreensão das modificações do espaço pelo homem, me interessei pela Faculdade de Saúde Pública, visto que é uma escola que foca na interdisciplinaridade, valorizando os diversos olhares dos estudantes que ali ingressam. No Programa de Pós-Graduação em Ambiente, Saúde e Sustentabilidade (mestrado profissional), fui apresentado à minha orientadora, jornalista, mestre em Política Científica e Tecnológica e doutora em Ambiente e Sociedade, que havia iniciado um estudo na comunidade do Real Parque (subprefeitura do Butantã, São Paulo), no âmbito do Projeto de Pesquisa "Clima, ambiente urbano e qualidade de vida: um estudo sobre riscos e sustentabilidade na cidade de São Paulo", financiado pela Fapesp ${ }^{1}$. No escopo desse projeto, delineamos que a minha pesquisa focaria na compreensão do processo de reurbanização dessa ocupação urbana, incluindo questões de percepção de risco, vulnerabilidade e qualidade de vida na perspectiva dos moradores.

Os resultados obtidos nestes pouco mais de dois anos de pesquisa são compartilhados nas páginas seguintes. Com estes apontamentos e análises, espero contribuir com o debate atual sobre cidades e reurbanização, destacando a importância de análises focadas nas percepções e compreensões dos próprios beneficiados e envolvidos nos processos de revitalização.

${ }^{1}$ O projeto coordenado pela orientadora foi aprovado pelo Comitê de Ética - Faculdade de Saúde Pública, Universidade de São Paulo, Plataforma Brasil, conforme Parecer 498.691. 


\section{$\underline{\text { INTRODUCÃO }}$}

Segundo dados da ONU, atualmente cerca de metade da humanidade vive nas cidades. As populações urbanas cresceram de cerca de 750 milhões em 1950 para 3,6 bilhões em 2011. Projeções apontam que, até 2030, quase $60 \%$ da população mundial viverá em áreas urbanas (ONU, 2012). O crescimento das cidades significa que elas serão responsáveis por prestar serviços a um número sem precedentes de pessoas, incluindo educação e habitação acessíveis, água potável e comida, ar limpo, um ambiente livre do crime e transporte eficiente. Contudo, projeções recentes do Programa das Nações Unidas para os Assentamentos Humanos (ONU-HABITAT) alertam que cerca de dois terços da população urbana mundial vivem em condições de favela, sem acesso ou com acesso restrito a esses serviços (ONU, 2012).

Um rápido olhar histórico mostra que a questão do urbanismo, que entrelaça a história do desenvolvimento das cidades com as populações que se expandem após a Revolução Industrial, se desdobra em diversos problemas e conflitos com os novos rearranjos que emergem. No Brasil, particularmente, a grande expansão urbana, como um componente fundamental das mudanças estruturais na sociedade brasileira, ocorreu na segunda metade do século XX, entre os anos de 1950 e 1970 (BRITO, 2006). Esse processo também foi acompanhado por uma ocupação desordenada que, até os dias atuais, traz suas consequências como ocupação de áreas de risco e aparecimento de favelas.

A migração interna em geral - e não só a rural-urbana - constituiu um dos elos mais importantes entre as profundas mudanças estruturais e a grande transformação urbana no país. O intenso crescimento da economia urbano-industrial - que se deu depois do Plano de Metas ${ }^{2}$ e se estendeu até o final dos anos de 1970 - foi, do ponto de

\footnotetext{
${ }^{2}$ Programa proposto pelo governo de Jucelino Kubtschek, que prometia 50 anos de progresso em 5 anos de realizações. Esse ideal desenvolvimentista foi consolidado num conjunto de 30 objetivos a serem alcançados em diversos setores da economia, que se tornou conhecido como Programa ou Plano de Metas. Na última hora o plano incluiu mais uma meta, a $31^{a}$, chamada de meta-síntese: a construção de Brasília e a transferência da capital federal, o grande desafio de JK. Disponível em: http://cpdoc.fgv.br/producao/dossies/JK/artigos/Economia/PlanodeMetas. Acesso em: 20 de Fev. 2017.
} 
vista espacial e social, extremamente desequilibrado. Muito concentrado no Estado do Rio de Janeiro e, mais ainda, em São Paulo, o desenvolvimento da economia ampliou os desequilíbrios regionais, inclusive entre a cidade e o campo, uma vez que este não conseguia gerar o número de empregos que atendesse ao crescimento da sua força de trabalho (BRITO, 2005). No Brasil como um todo, mas nestes estados, em particular, as periferias tiveram um crescimento elevado, nas décadas de 1970-80, que ainda se mantém alto, apesar de declinante, pois elas também sofrem o impacto da redução da fecundidade e das migrações (BRITO, 2005). Dados do Censo de 2010 mostram que o número de brasileiros vivendo nessas condições, em favelas, passou de 6,5 milhões no ano 2000 para 11,4 milhões em 2010, distribuídos em 6.329 aglomerados subnormais situados em 323 municípios; 88\% desses domicílios estão concentrados em 20 grandes cidades. Do total da população brasileira, os dados do Censo de 2010 indicam que aproximadamente $6 \%$ da população vive em domicílios localizados em aglomerados subnormais (PASTERNAK; D’OTTAVIANO, 2016).

A rápida urbanização do território brasileiro não é um processo estritamente demográfico. Tem dimensões muito mais amplas, já que é a própria sociedade brasileira que se torna cada vez mais urbana. Hoje, segundo dados do IBGE (2010), mais de 80\% da população brasileira vive nas cidades; no Estado de São Paulo esse número sobe para mais de $93 \%$. As cidades, além de concentrarem uma parcela crescente da população do país, convertem-se em lócus privilegiado das atividades econômicas mais relevantes e transformam-se em difusoras dos novos padrões de relações sociais - incluindo as de produção - e de estilos de vida (BRITO, 2006).

O processo de urbanização, baseado na terra como mercadoria, que gerou enormes vazios urbanos e causou a expansão do tecido urbano para especular com a terra (SINGER, 1973; SANTOS, 1994; CARLOS, 2008), trouxe diversos problemas para boa parte das cidades brasileiras (particularmente as maiores), como ocupação de margens dos rios, lançamentos de resíduos em cursos d'água e terrenos vazios, ocupação de encostas, saneamento básico insuficiente, habitações insalubres, trânsito, ruído e poluição (JACOBI, 2006; BONDUKI, 2011).

São Paulo, a cidade mais populosa do país e o principal centro financeiro, corporativo e mercantil da América do Sul, é representativa desse processo. A cidade 
brasileira mais influente no cenário global em diferentes aspectos é um polo de atração das mais diversas pessoas em busca de melhores oportunidades, melhores condições de vida, de ascensão social e, por este motivo, se destaca também pela sua grande desigualdade social. Para o arquiteto Carlos Leite, as chamadas megacidades, cidades com mais de 10 milhões de habitantes, como é o caso da capital paulista com mais de 12 milhões de habitantes (IBGE, 2015), são complexas e interligadas, e nelas se estabelecem as grandes conexões, fluxos globais, fontes de inovações e liderança de processos transformativos (LEITE, 2010; SETO et al. 2010).

Segundo Pasternak e D’Ottaviano (2016), a Região Metropolitana de São Paulo apresenta a maior concentração de favelas do Brasil, com 1.703 aglomerados (27\% do total de favelas brasileiras), com mais de 2 milhões de pessoas vivendo nestes aglomerados (o que representa $19 \%$ da população brasileira que vive em favelas). A proporção de domicílios favelados vem aumentando desde 1991: de 5,71\% em 1991, 8,4\% em 2000 para 9,79\% em 2010 (PASTERNAK; D’OTTAVIANO, 2016). Para o município de São Paulo, particularmente, entre 1991 e 2000, a população que vive em favela cresceu mais do que a população como um todo: $2,5 \%$ ao ano, enquanto a municipal aumentou a uma taxa de 0,92\% anuais. Entre 2000 e 2010, essas taxas se mantiveram maiores que as municipais, atingindo valores superiores aos da década de 1990: 3,22\% ao ano, para uma população municipal com crescimento de 0,76\% anuais, mais do que quatro vezes o crescimento municipal (PASTERNAK; D’OTTAVIANO, 2016).

Num olhar superficial, a cidade pode ser um conjunto de edificações, ruas e avenidas que são construídas em um sítio, com suas características geográficas, com vales, colinas, declives que devem acomodar fluxos de pessoas e veículos, comércios, fábricas, aterros sanitários, shoppings (MELLO, 2010); contudo, para muito além disso, a cidade é um fluxo constante de mudanças, de alterações em sua composição, já que diariamente novos espaços vão sendo produzidos e reproduzidos pelos indivíduos que a compõem. Conforme Hissa e Melo (2008), a cidade é a vida das relações de todas essas coisas e de todas as coisas que ela abriga, segundo várias dimensões (política, religiosa, ecônomica, social, jurídica) que se reproduzem no panorama da desigualdade (HISSA; MELO, 2008). 
A cidade pode ser compreendida como uma rede estruturada no contexto de instituições políticas e da sociedade civil, dinamizada por atores e múltiplos centros de poder, que se articulam por meio da ação coletiva e conjunta por vários meios e para vários fins, relacionados aos agentes externos, aos produtos, aos projetos e à ação política (CASTELLS; BORJA, 1996). Quanto às funções, segundo esses mesmos autores, as cidades devem responder a cinco tipos de objetivos: nova base econômica, infraestrutura urbana, qualidade de vida, integração social e governabilidade para, por um lado, serem competitivas para o exterior e inserirem-se nos espaços econômicos globais e, por outro, darem garantia a sua população de um mínimo de bem-estar para que a convivência democrática possa se consolidar.

Assim, na perspectiva da dialética entre habitação, produção e consumo (funções que são cumpridas tanto pelo setor público quanto pelo privado), a administração das cidades deve oferecer redes viárias, de água, de esgoto, e demais serviços coletivos, além de cuidar da terra urbana, suporte material receptor de todas as benfeitorias. Contudo, a distribuição espacial das funções públicas expressa também formas de segregação socioeconômicas profundas (MELLO, 2010). Para Kowarick (2000), nas cidades contrastam de maneira radical as restritas áreas privilegiadas, destinadas aos estratos médios e de alto poder aquisitivo, com as imensas zonas onde se avolumam os indivíduos com condições socioeconômicas mais precárias (KOWARICK, 2000).

\section{AS CIDADES E O ACESSO À MORADIA}

Cardoso (s.d.) $)^{3}$ destaca que é importante que se considere que a sobrevivência na cidade depende fundamentalmente do acesso à moradia, como mote para o seu desenvolvimento. Além da saúde, da renda e da educação, a habitação é um elemento básico que constitui um "mínimo social”, que habilita os indivíduos e os grupos sociais a fazerem escolhas e desenvolverem suas capacidades. Desde esta perspectiva, a habitação é um direito básico de cidadania, assim compreendida no debate internacional

\footnotetext{
${ }^{3}$ Disponível em:

http://www.observatoriodasmetropoles.ufrj.br/download/adauto_desig_urb_polhab.pdf. Acesso em: 17 de Jan. de 2017.
} 
desde a Declaração Universal de Direitos Humanos, de 1948, até a Declaração de Istambul sobre Assentamentos Humanos, de 1996, que reafirmou o compromisso dos governos nacionais com "a completa e progressiva realização do direito à moradia adequada" e estabeleceu como um objetivo universal que se assegure "abrigo adequado para todos e que se façam os assentamentos humanos mais seguros, mais saudáveis e mais agradáveis, eqüitativos, sustentáveis e produtivos" (CARDOSO, s.d.). No Brasil, o direito à moradia, como argumenta este autor, foi reconhecido mediante a Emenda Constitucional 26/2000, que altera o art. $6^{\circ}$ da Constituição Federal, fazendo constar a moradia entre os direitos sociais. Por outro lado, a habitação é, direta ou indiretamente, fruto de um processo de produção capitalista. Este processo de produção, diferentemente de outros setores econômicos, tem como base de sua lucratividade a apropriação dos benefícios gerados pela extrema diferenciação do espaço urbano em termos de equipamentos, serviços e amenidades (CARDOSO, s.d.; DAVIS, 2006; CARLOS, 2009).

Como sustenta Cardoso (s.d.), tendo em vista o histórico déficit na oferta de serviços públicos urbanos que marca a maioria das cidades brasileiras, os processos privados de produção habitacional tendem a adotar um comportamento especulativo, retendo a terra na espera da valorização e apostando sempre na elevação dos preços relativos. O resultado deste processo é que a produção privada atinge apenas um pequeno grupo social, que consegue se apropriar das melhores condições de acessibilidade às áreas centrais, melhores ofertas de infraestrutura e maior nível de amenidades (CARDOSO, s.d.). Assim, na perspectiva desse autor, gera-se uma identificação de determinados espaços da cidade com certos grupos sociais dominantes, e a exclusão de outras parcelas da população da utilização destes bens. Consequentemente, as ocupações ilegais e irregulares, presentes na maioria dos municípios brasileiros (HOLZ; MONTEIRO, 2008), incluindo São Paulo, evidenciam um dos mais graves problemas sociais no país: a falta de moradia.

Todavia, o problema não é apenas a falta de imóveis para morar, mas também a ausência da segurança de posse que, por sua vez, favorece a baixa qualidade com que são construídos os que existem, em especial nas áreas ilegais (HOLZ; MONTEIRO, 2008). Funes (2005), numa perspectiva mais ampla, argumenta que o principal agente 
da exclusão territorial e da degradação ambiental nas cidades é a segregação espacial, que traz consigo diversos problemas sociais e econômicos, tendo como conseqüência a exclusão e a desigualdade social que propiciam a discriminação, geram menos oportunidades de emprego, dentre outros problemas, ocasionando assim uma perpetuação da pobreza e a ausência do exercício da cidadania (FUNES, 2005).

Dentro do seu contexto histórico, a formação de áreas ilegais no Brasil está diretamente relacionada ao processo excludente da urbanização e da produção de habitação pelo Estado durante todo o século XX. O mercado imobiliário capitalista, os baixos salários e a desigualdade social presente desde o início da formação da sociedade brasileira impossibilitaram o acesso à moradia para grande parte da população que, principalmente nas últimas décadas, vêm sendo produto e produtor dos processos de periferização, segregação, degradação ambiental, má qualidade de vida e violência nas cidades (HOLZ; MONTEIRO, 2008).

Para Davis (2006), o crescimento da cidade ilegal (ou informal), na qual as famílias se apossam da terra sem compra nem título de posse, passou a ser discutido como a mina de ouro do urbanismo. A especulação imobiliária é corrente na realidade brasileira, com cerca de 1/3 dos espaços para construção ainda vagos na expectativa de valorização, expulsando a população de baixa renda para as áreas ilegais, onde a especulação também já acontece (DAVIS, 2006). Este autor estima ainda que apenas $20 \%$ da população que necessita de habitação têm possibilidade de pagá-la e que os $80 \%$ restantes, além da ausência da renda, não apresentam o perfil para assumir os financiamentos existentes.

Historicamente, o acesso à moradia para a população de baixa renda no Brasil se deu, em geral, de forma precária e a partir de três tipos básicos de moradia: os cortiços, as favelas e os loteamentos periféricos, com moradia própria e autoconstrução (PASTERNAK; D’OTTAVIANO, 2016). 


\section{SÃO PAULO E A CIDADE INFORMAL}

O déficit habitacional é um grave problema para as grandes cidades brasileiras, como São Paulo. Esse déficit está relacionado às carências de determinados grupos sociais, seja pela falta de moradia, seja pela ausência de condições adequadas de habitações, e é dado pelo resultado entre a subtração da demanda pela oferta de bens com caráter social (GARCIA; CASTELO, 2006). Um estudo sobre assentamentos precários, efetuado pelo Centro de Estudos da Metrópole (CEM) em 2013, desenvolvido para a Fundação do Desenvolvimento Administrativo (FUNDAP) a pedido da Empresa Paulista de Planejamento Metropolitano (EMPLASA), intitulado "Diagnóstico dos

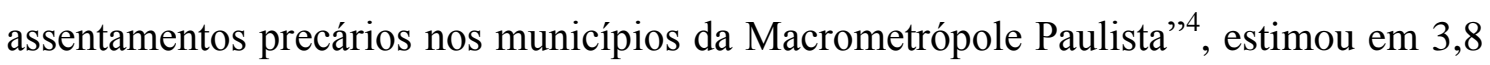
milhões de habitantes a população em assentamentos precários no ano de 2010 no conjunto da macrometrópole (Região Metropolitana de São Paulo - RMSP; Campinas RMC, Baixada Santista - RMBS e Vale do Paraíba e Litoral Norte - RMVP-LN, além da Aglomeração Urbana de Jundiaí). Este estudo se baseou nas informações dos últimos censos do Instituto Brasileiro de Geografia e Estatística (IBGE) e seu resultado apontou para a existência de um número muito maior de moradores nesse tipo de assentamento do que quando consideradas apenas as informações dos levantamentos censitários relativos aos setores subnormais (CEM/FUNDAP, 2013). As análises dos pesquisadores confirmam que, de fato, existe um problema profundo em relação ao processo de ocupação urbana no Estado de São Paulo, colocando em contraponto os assentamentos precários, condomínios de alto padrão e a desigualdade social gerada pela falta de planejamento e oportunidades de inserção social.

Particularmente para a cidade de São Paulo, o mesmo relatório mostrou que de um total de 3.561.505 domicílios da cidade, 356.692 estão em setores sobnormais e 111.331 em setores precários - o que representa 13,14\% de domicílios em assentamentos precários. Quando as estimativas se referem ao número de indivíduos, os dados revelam que mais de $15 \%$ residem em assentamentos precários em áreas urbanas na cidade (CEM/FUNDAP, 2013).

\footnotetext{
4 "Diagnóstico dos assentamentos precários nos municípios da Macrometrópole Paulista". Disponível em: $\quad$ http://www.fflch.usp.br/centrodametropole/upload/aaa/654Relatorio\%20II_Assentamentos_Fundap_final_logo.pdf. Acesso em: 14 de Jul. 2015.
} 
Mais recentemente, o Centro de Estudos da Metrópole também divulgou dados atualizados sobre favelas e loteamentos irregulares no Município de São Paulo, apontando que 361.831 domicílios e 1.307 .152 pessoas estão distribuídos em 2.098 favelas na cidade. Os dados censitários de 2010, base desses números, revelam uma taxa de crescimento anual de 2,2\% dos domicílios em favelas ${ }^{5}$.

Na metrópole de São Paulo, as diferenciações gritantes no plano da paisagem revelam, como observa Carlos (2009), os espaços-tempos da contradição entre os espaços integrados à economia global e as imensas periferias subordinadas e em fase de desintegração. Isso significa, na perspectiva dessa autora, que é necessário pensar o processo de urbanização em seus conteúdos mais profundos, o que é muito diferente de associá-lo ao simples comportamento populacional (CARLOS, 2009).

Ainda para a autora, trata-se de um processo no qual a urbanização se faz como explosão da cidade, extensão da mancha urbana abrigando a classe trabalhadora em imensas periferias sem infraestrutura. Na sua perspectiva, o modo como o processo de industrialização se realizou gerou uma urbanização profundamente desigual, criando separações entre o centro e a periferia como particularidade da metrópole em constituição. Com isso localizou uma massa expressiva de trabalhadores em áreas sem equipamento e moradias precárias (CARLOS, 2009).

Estudos focados no processo de urbanização da cidade de São Paulo revelam que a dinâmica de expansão da metrópole tem provocado um processo de concentração de população de baixa renda em áreas periféricas, enquanto as áreas centrais vão sendo renovadas e adensadas, a um preço crescente da terra urbana. Esse padrão de ocupação promove a expansão da mancha urbana junto às áreas de proteção ambiental, em especial às áreas de proteção aos mananciais, definidas pela Lei 9866/97. A dificuldade para a implementação de mecanismos efetivos para a proteção destas áreas faz com que estas sofram enorme pressão de ocupação, reverberando em situações de vulnerabilidade, que se revelam em suas dimensões ambiental e social (JACOBI, 2006). Contudo, este processo de produção do espaço metropolitano que empurra para as

\footnotetext{
${ }^{5}$ Disponível em: http://www.fflch.usp.br/centrodametropole/1289. Acesso em: 20 de Fev. 2017.
} 
franjas da cidade parte da população com menor poder aquisitivo e condições socioeconômicas mais precárias não se restringe às áreas de proteção ambiental ou às áreas mais longínquas da megacidade. Outras localidades concentram bolsões de pobreza e abrigam população de baixa renda, com processos de ocupação por atividades irregulares, como invasões, favelas e loteamentos clandestinos.

Exemplo de uma dessas áreas é a antiga favela do Real Parque, situada no bairro do Real Parque, um dos cinco bairros que compõem o distrito do Morumbi, na subprefeitura do Butantã $\tilde{a}^{6}$. Esta região é um espaço representativo das diferenças e contrastes encontrados na cidade de São Paulo e expressa uma lógica de ocupação e reestruturação urbana caracterizada pela inserção de parte da comunidade numa localidade cercada por condomínios de alto padrão e que foge das características de seu entorno. Como argumenta Rezende (2015), as características da favela do Real Parque sempre foram centradas em seus contrastes: ao mesmo tempo que possibilitava a oferta de trabalhos aos seus residentes próxima às moradias, acesso a transportes e equipamentos públicos; também impulsionava tensão permanente entre a área de ocupação irregular e seu entorno, com moradores vivendo em um bairro caro, o que lhes impossibilitava o consumo em comércio e serviços da região (REZENDE, 2015).

Um estudo do IPT (Instituto de Pesquisas Tecnológicas), realizado entre 2003 e 2004, identificou esta localidade do Real Parque como área de risco geológico, associada a movimentos de massa, erosão, inundação e solapamento de margens de córrego na favela do Real Parque (MIRANDOLA, 2003). Naquele momento, as alternativas propostas foram a remoção de moradias e execução de obras de drenagem e proteção superficial na encosta e/ou obras de terraplenagem. Foram sugeridos ainda serviços de limpeza, verificação períodica das condições das obras de contenção, entre outros, para que, a partir do mapeamento elaborado, os órgãos competentes pudessem estabelecer um plano de gestão urbana para a área em questão (MIRANDOLA, 2003).

\footnotetext{
${ }^{6}$ A subprefeitura do Butantã, ou Prefeitura Regional do Butantã (nova nomenclatura vigente a partir de 2017) contabiliza uma população de 428.217 habitantes (Infocidade, 2016); o distrito do Morumbi soma 50.920 habitantes (Fundação Seade, 2016). O Real Parque conta com uma população estimada em 5.300 habitantes (METRO - EIA RIMA). Disponível em: http://www.prefeitura.sp.gov.br/cidade/secretarias/upload/meio_ambiente/arquivos/MSE_6.4. 1_6.4.4.pdf. Acesso em: 21 de Fev. 2017.
} 
Em 2008, por iniciativa da Secretaria Municipal de Habitação (SEHAB), as obras de reurbanização para a área começaram a ser discutidas, com a proposta de manutenção das famílias residentes na localidade e construção de prédios, buscando menor disparidade da questão urbana, melhor condição de vida e diminuição das moradias consideradas de risco (SEHAB/FAU, 2009). Na época, o projeto de reurbanização não foi bem recebido por alguns moradores de prédios vizinhos de alto padrão. O motivo da discórdia era que parte dos conjuntos habitacionais seria construída em dois terrenos que custaram à prefeitura $\mathrm{R}$ \$ 7,5 milhões. Moradores argumentavam ainda que a prefeitura, ao ampliar o perímetro da favela, deixaria espaços livres, nos quais poderiam surgir novas construções precárias; questionavam também a ausência de estudos de impacto ambiental e sobre o trânsito da região ${ }^{7}$.

Os moradores vizinhos entraram com várias ações judiciais para tentar evitar a construção do conjunto, com acusações quanto à expansão indevida da favela que se daria com as desapropriações e questionamentos sobre o trâmite de aprovação do conjunto. Essas ações impactaram no encaminhamento do projeto legal pela Prefeitura Municipal, que conseguiu a aprovação antes da entrega das unidades, fato raro para os projetos de habitação (NAKAMURA, 2016).

Se por um lado o processo de construção dos edifícios na região da antiga favela do Real Parque faz com que os residentes da área não corram o risco de desapropriações dos terrenos, visto que com o estabelecimento de moradias dignas cria-se a questão de vínculo urbano, não permitindo que manobras imobiliárias removam as populações que ali vivem; por outro, a área do entorno ao projeto, com valor de imóveis muito elevado pela sua localização neste novo polo do setor terciário na cidade de São Paulo, torna a região alvo de problemas de segregação espacial, que, mesmo com a reurbanização, não insere necessariamente a população da área nos benefícios da localidade.

\footnotetext{
${ }^{7}$ Disponivel em: http://vejasp.abril.com.br/cidades/revitalizacao-da-favela-real-parque-estaem-xeque/. Acesso em: 02 de Fev. 2017.
} 


\section{A PESQUISA REALIZADA}

Pelas suas especificidades, esse território do Real Parque é um estudo de caso ilustrativo para pensar os contrastes da megacidade, os impactos da urbanidade (ou da sua falta), a conformação de áreas de ocupação irregular e as relações estabelecidas pelos seus moradores e os possíveis delineamentos de processos de reurbanização. Neste sentido, a pesquisa realizada teve como objetivo geral compreender, na perspectiva dos moradores, as potencialidades e limitações do processo de reurbanização, que teve início em 2008 e seguiu até 2016, com a entrega dos últimos condomínios. Como objetivos específicos, buscou-se investigar as características dessa localidade, particularmente antes do início da reurbanização; identificar percepções dos moradores sobre o local onde vivem e condições de vulnerabilidades; e compreender, a partir das suas narrativas, como as mudanças relacionadas ao novo empreendimento têm impactado o cotidiano da comunidade. O estudo partiu da hipótese de que enquanto os riscos geológicos foram minimizados e/ou se tornaram inexistentes, outros problemas e condições de vulnerabilidade passaram a ganhar maior visibilidade e projeção para os moradores.

O estudo realizado envolveu pesquisa documental e pesquisa de campo, ancorando-se em um referencial teórico sobre urbanização e vulnerabilidade e em arranjos conceituais que nortearam a análise do material coletado, como lugar, pertencimento, identidade e qualidade de vida. Metodologicamente, o estudo incluiu a realização de grupos focais e entrevistas, observação de reuniões, registros visuais e análise do material coletado, a partir de categorias estabelecidas.

A dissertação ora apresentada, fruto deste estudo, está estruturada em três capítulos, para além desta Introdução e das Considerações Finais. O capítulo 1 traz elementos sobre a ocupação irregular do Real Parque, as características dessa área e a proposta de reurbanização sugerida pela Secretaria Municipal de Habitação da Prefeitura Municipal de São Paulo. No capítulo 2, é apresentada detalhadamente a metodologia da pesquisa. No capítulo 3 , os resultados da pesquisa são apresentados e discutidos à luz do referencial teórico adotado, a partir das três categorias analíticas: (i) o antes e o depois do processo de reurbanização e as mudanças nas condições de 
vulnerabilidade; (ii) lugar, pertencimento e identidade; (iii) demandas e necessidades para melhorar a qualidade de vida dos moradores. Propositadamente, a revisão da literatura é apresentada neste capítulo 3, estabelecendo um diálogo com os resultados obtidos. Nas considerações finais da dissertação, são retomadas as principais contribuições da pesquisa e apresentadas vias futuras de estudo. Espera-se ainda que os dados gerados e analisados possam servir como subsídios para que gestores locais (a subprefeitura do Butantã, por exemplo) possam, a partir da compreensão sobre a lógica espacial da região e dos apontamentos da comunidade local, pensar e propor investimentos em diversas esferas sociais e urbanas. 


\section{CAPÍTULO 1: O CASO REAL PARQUE}

O conceito de favela ou de aglomerado subnormal é compreendido pelo IBGE como aglomerado constituído por no mínimo 51 unidades habitacionais (casas, barracos etc.) ocupando ou tendo ocupado, até período recente, terreno de propriedade alheia (pública ou particular), dispostas, em geral, de forma desordenada e densa. Em sua maioria são carentes de serviços públicos essenciais (IBGE, 2010). Somente na segunda metade do século XX, o IBGE decidiu incluir a favela na contagem da população e, para São Paulo, isso ocorreu apenas em 1980. A conceituação de favelas era dada por um grupo de moradias que tivessem pelo menos duas das características a seguir: (i) proporções mínimas - agrupamentos prediais ou residenciais formados com número geralmente superior a cinquenta; (ii) tipo de habitação - predominância de casebres ou barracões de aspecto rústico, construídos principalmente com folha de flandres, chapas zincadas ou materiais similares; (iii) condição jurídica da ocupação - construções sem licenciamento e sem fiscalização, em terrenos de terceiros ou de propriedade desconhecida; (iv) melhoramentos públicos - ausência, no todo ou em parte, de rede sanitária, luz, telefone e água encanada; (v) urbanização - área não urbanizada, com falta de arruamento, numeração ou emplacamento (GUIMARÃES, 2000, p. 353).

A partir do Censo de 1991, o IBGE passou a adotar o conceito de aglomerado subnormal. O conceito, bastante genérico, buscava abarcar a diversidade dos assentamentos irregulares existentes no país. Neste sentido, aglomerado subnormal inclui favelas, invasões, grotas, baixadas, comunidades, vilas, ressacas, mocambos, palafitas, entre outros. Foi nesse Censo Demográfico que os dados relativos às favelas foram levantados de forma homogênea por todo o país (PASTERNAK; D’OTTAVIANO, 2016). No último censo nacional, de 2010, foi possível observar avanços em relação à identificação e levantamento de dados dos aglomerados subnormais, a partir de uma pesquisa morfológica específica, com a identificação georeferenciada e visita de campo preparatória nos aglomerados, o que permitiu maior confiabilidade nos dados gerados (PASTERNAK; D’OTTAVIANO, 2016). O Censo 2010 identifica um aglomerado subnormal a partir dos seguintes critérios: (i) ocupação ilegal da terra, ou seja, construção em terrenos de propriedade alheia (pública ou particular) no momento atual ou em período recente (obtenção do título de propriedade 
do terreno há dez anos ou menos); (ii) urbanização fora dos padrões vigentes (refletido por vias de circulação estreitas e de alinhamento irregular, lotes de tamanhos e formas desiguais e construções não regularizadas por órgãos públicos) ou precariedade na oferta de serviços públicos essenciais (abastecimento de água, esgotamento sanitário, coleta de lixo e fornecimento de energia elétrica) (IBGE, 2011).

Na cidade de São Paulo, o Sistema Municipal de Habitação entende favelas como "aglomerados de moradias de reduzidas dimensões, construídas com materiais inadequados (madeira velha, zinco, latas e até papelão) distribuídos irregularmente em terrenos quase sempre desprovidos de serviços e de equipamentos urbanos e sociais, compondo um complexo de ordem social, econômica, sanitária, educacional e urbanística" (INFOCIDADE - PREFEITURA DE SÃO PAULO, 2015). Núcleos são definidos como aglomerados com até dez domicílios. Contudo, desde que a Secretaria Municipal de Habitação (SEHAB) passou a trabalhar com indicadores para diagnosticar e intervir em áreas de ocupação precária na cidade, tais conceituações têm exigido do próprio órgão uma revisão desses critérios (INFOCIDADE - PREFEITURA DE SÃO PAULO, 2015).

Para compreender o histórico de ocupação da área estudada na pesquisa realizada é necessário entender o processo que constituiu a favela do Real Parque, desde seu início. Segundo o antropólogo Athias (2003, 2007), a favela do Real Parque começou a ser formada em 1956, quando os índios Pankararu decidiram procurar emprego em São Paulo, deixando Pernambuco, onde viviam, dada à seca que atingiu esta região. Naquele momento, grandes obras eram construídas na região do Morumbi (o Estádio Cícero Pompeu de Toledo - Morumbi, nos anos de 1952-1970 e o Palácio dos Bandeirantes, sede do Governo do Estado de São Paulo, entre 1955-1965). Dada à necessidade de mão de obra nestes empreendimentos, essa população indígena fixou moradia nas proximidades, constituindo ali uma ocupação com moradias de papelão e madeira, dando início, assim, ao que mais tarde se tornaria a favela do Real Parque (FRANÇA, 2008), como evidenciam a imagem 1, uma foto aérea do Real Parque na década de 1950, região ainda pouco ocupada, e o mapa 1, que mostra a área do Real Parque em 1952, com um círculo destacando a área de estudo. As fotos 1 e 2 de 2010 mostram a área do Real Parque mais atual, com a ocupação e urbanização mais recentes. 


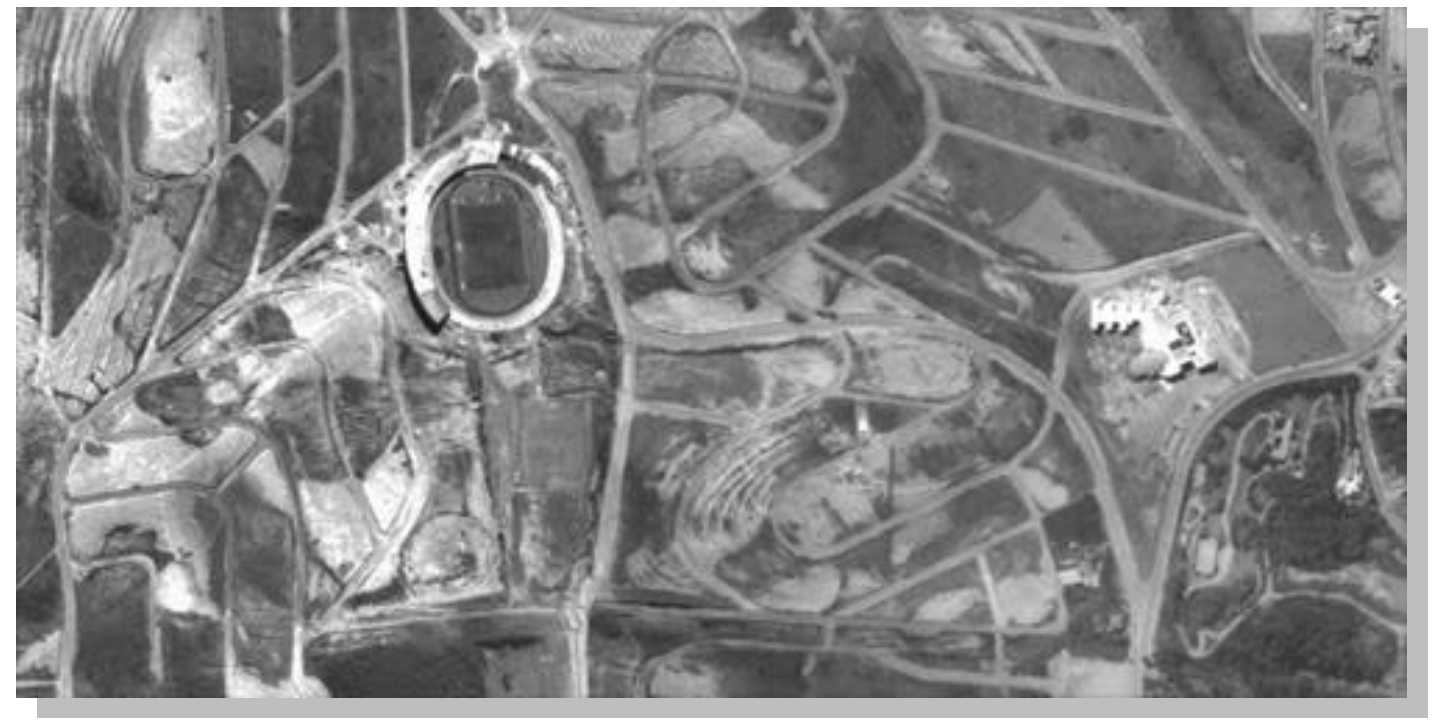

Imagem 1: Foto antiga do bairro e do estádio do Morumbi na década de 1950

Fonte: http://www.encontramorumbi.com.br/imgs/imagens-morumbi/estadio-do-morumbibairro-morumbi-anos-50.jpg

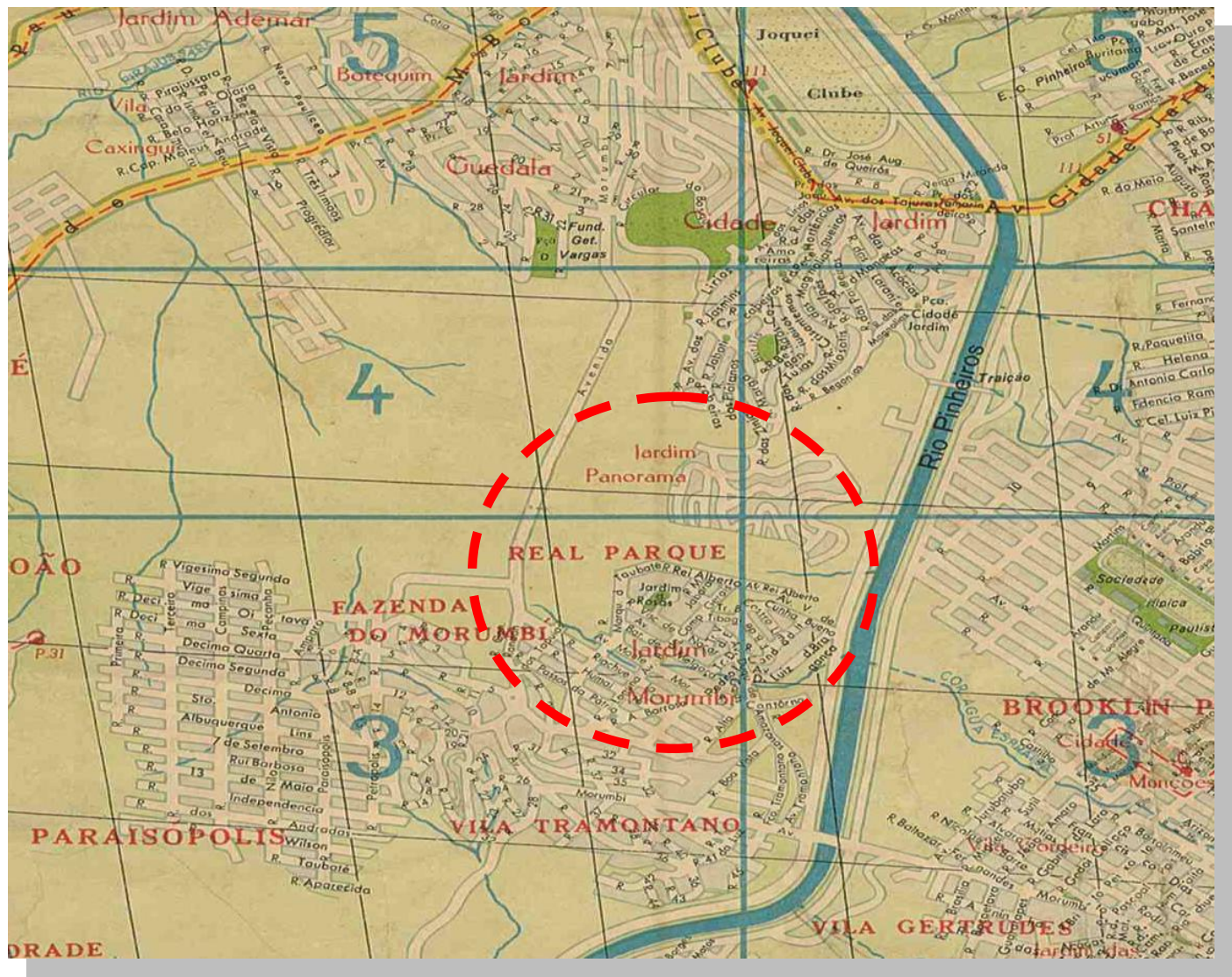

Mapa 1: Mapa da área do Real Parque: 1952

Fonte: http://smdu.prefeitura.sp.gov.br/historico_demografico/img/mapas/1952.jpg 


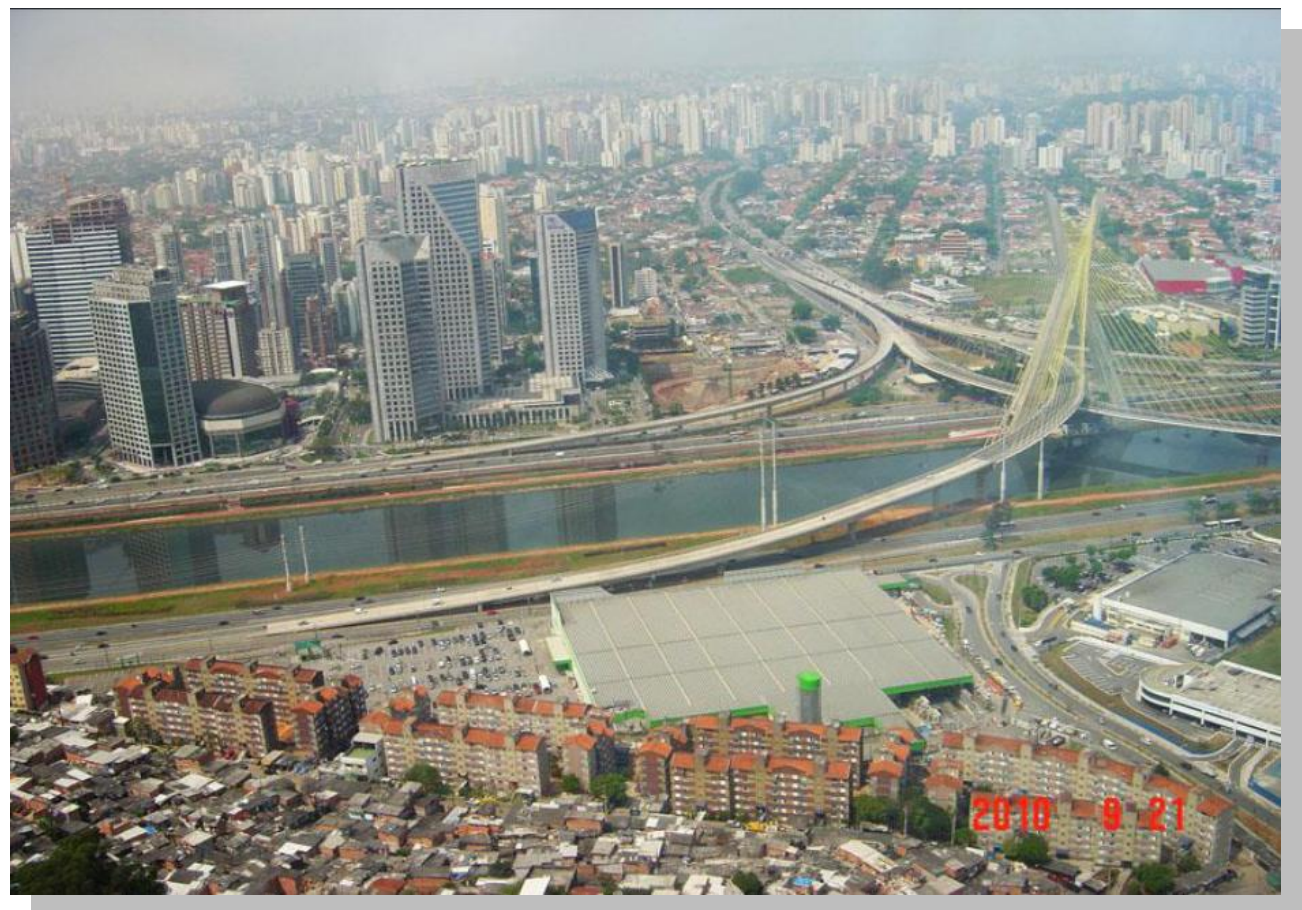

Foto 1: Real Parque em 2010 (foto aérea)

Fonte: SEHAB, 2009

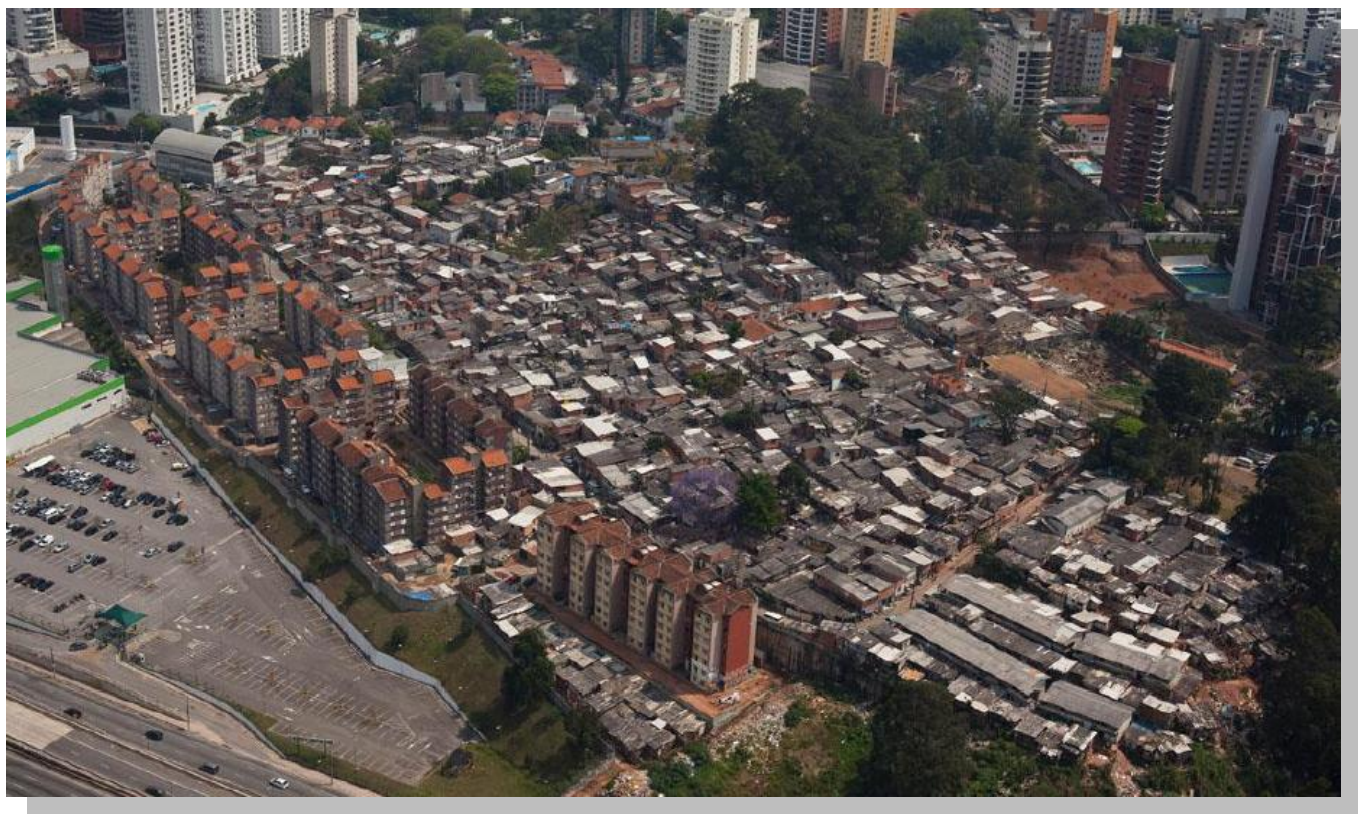

Foto 2: Real Parque em 2010 (foto aérea)

Fonte: SEHAB, 2009 
Dados de um levantamento realizado pela ONG Projeto Casulo, que atua na favela Real Parque desde 2003 e tem por missão contribuir para a melhoria da qualidade de vida da população do Real Parque e Jardim Panorama (foto 3 da fachada da sede do Projeto), confirmam que grande parte da comunidade que deu início à ocupação era proveniente do sertão de Pernambuco, pelo menos no seu início. Entre esses pernambucanos, há uma significativa parcela afro-brasileira e indígena (Pankararus) que foi trazida para São Paulo em diferentes momentos no período entre 1950 e 1970 para a construção das obras mencionadas.

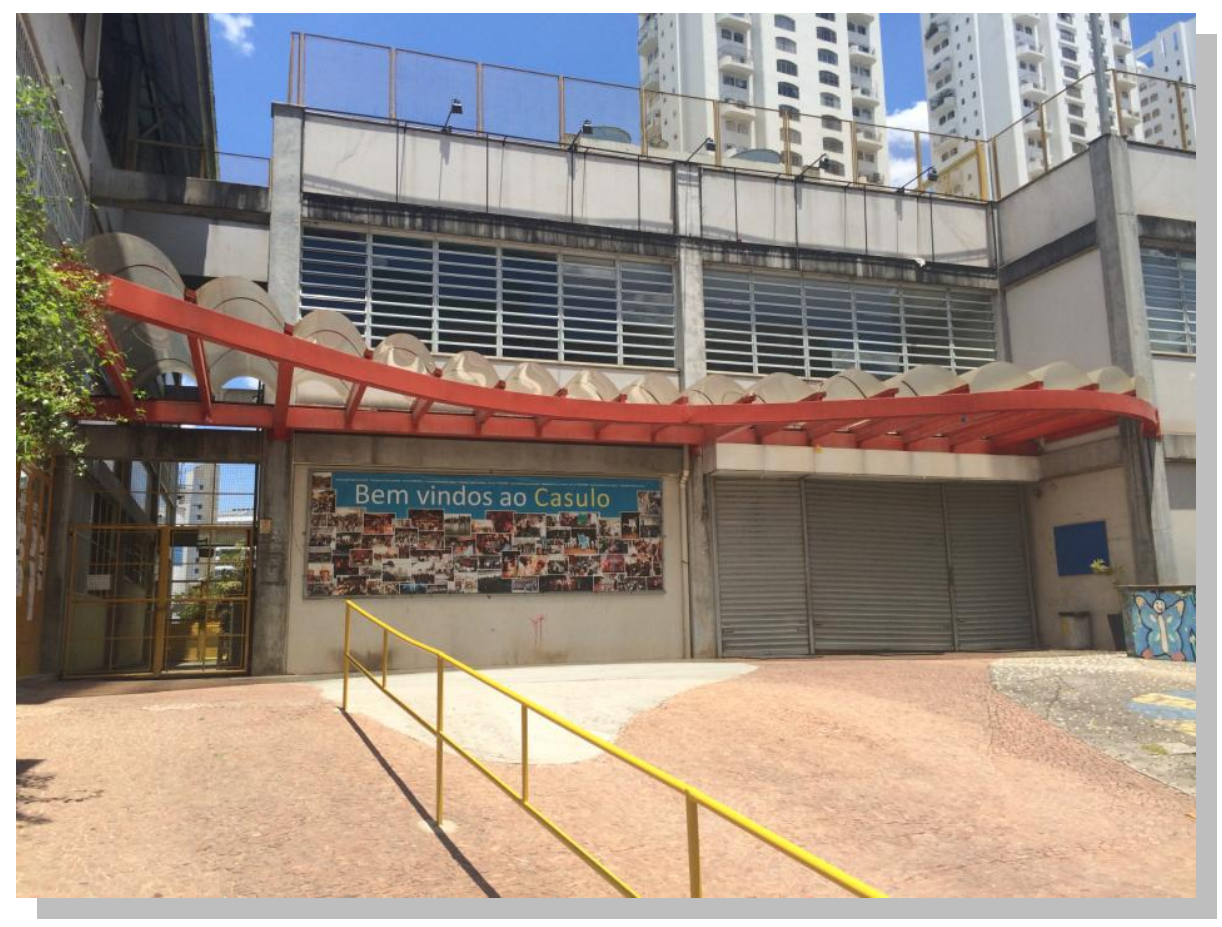

Foto 3: Fachada da sede do Projeto Casulo, localizada próximo à antiga favela do Real Parque Foto: Tiago Prado

O processo migratório da população dessa área ocupada compreende movimentos de territorialização, desterritorialização e reterritorialização (SANTOS, $2007)^{8}$, que acompanham o percurso da comunidade desde os aldeamentos forçados do

${ }^{8}$ Conceito de Milton Santos (Por uma outra globalização: do pensamento único à consciência universal, Rio de Janeiro, Record, 2007) que expressa a contínua ruptura e mudança de lugar, a necessidade de constantes desenraizamentos e perda de vínculos. 
Brejo dos Padres, no sertão de Pernambuco, no início do século XIX, até as favelizações dos séculos XX e XXI (FERREIRA, 2012).

O intenso fluxo migratório deste e de outros grupos populacionais de todo o país para o Sudeste brasileiro deve-se ao fato de a região paulistana ter se tornado um polo da industrialização e modernização nacional no decorrer do século XX. A ampliação das relações capitalistas no campo, a mecanização da agricultura e a grande especulação imobiliária foram fenômenos que produziram a exclusão dos benefícios da modernização para muitos trabalhadores rurais. Ao mesmo tempo, a cidade - em especial São Paulo -, se vista sob a ótica do trabalho assalariado, apresentava-se como uma extraordinária fonte de empregos. Enquanto o campo expulsava, a cidade atraía (SCARLATO, 2005).

A ocupação do Real Parque e a própria expansão e urbanização da cidade de São Paulo desvelam a ideia de polo de crescimento, associada à política de concentração de investimentos, que reafirmou o caráter centralizador do país e acelerou o seu quadro caótico de organização e integração territorial. Consequentemente, as cidades, e São Paulo é um exemplo disso, não foram feitas apenas de vidro e aço, como fora previsto por gerações anteriores de urbanistas, mas construídas em grande parte de tijolo aparente, palha, plástico reciclado, blocos de cimento e restos de madeira (DAVIS, 2006), como a ocupação do Real Parque evidenciou durante muitos anos.

Para compreender as especificidades da área estudada é preciso também rever o plano habitacional adotado na cidade de São Paulo, cujas políticas implementadas também tenderam à segregação socioespacial da população de baixa renda. O Banco Nacional de Habitação (BNH), criado em 1964, visava atender à demanda de habitação para a classe trabalhadora, mas acabou transformando-se em uma instituição de acumulação de capitais, como argumenta Scarlato (2005). Financiou habitações para a classe média e estimulou a verticalização e o adensamento da cidade, cobrando parcelas e taxas inacessíveis às populações de baixa renda. Em São Paulo e na região metropolitana, a necessidade de habitação levou a Companhia Metropolitana de Habitação (COHAB) a ocupar grandes áreas vazias com gigantescas construções de moradia popular localizadas em pontos distantes do centro (SCARLATO, 2005). Sua padronização e a maneira como foram alinhados os edifícios, com pouco ou sem 
cuidado na criação de uma paisagem integradora do indivíduo com seu espaço, fizeram com que uma grande parte desses conjuntos de casas e edifícios se apresentasse como uma massa de cimento desprovida de praças e jardins, distantes dos lugares de trabalho e de lazer que a cidade pode oferecer (SCARLATO, 2005).

No site da Prefeitura de São Paulo é apresentado o Histórico Demográfico do Município de São Paulo, editado pela Secretaria Municipal de Desenvolvimento Urbano, no qual é possível acompanhar mais de 100 anos de evolução da cidade de São Paulo, por meio de informações censitárias colhidas desde 1872 , data do $1^{\circ}$ censo demográfico feito no Brasil, até o mais recente, realizado em 2010, como mostram os mapas 2, 3 e 4 a seguir. É possível com os mapas comparar a ocupação e a evolução da área urbanizada entre a década de 1930 até o ano de 2002. 


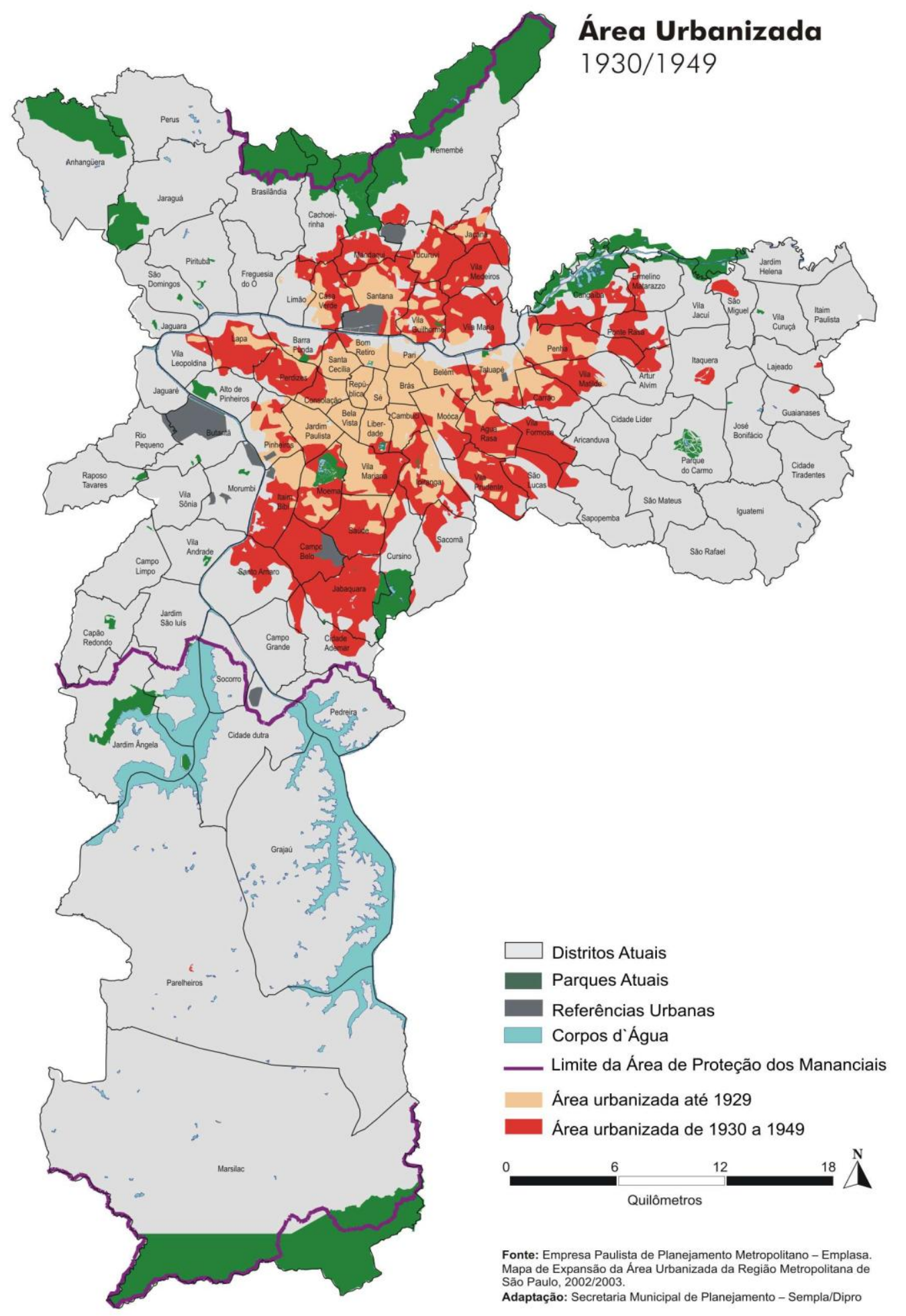

Mapa 2: Histórico demográfico do Município de São Paulo - área urbanizada 1930-1949 Fonte: http://smdu.prefeitura.sp.gov.br/historico_demografico/img/mapas/urb-1940.jpg 


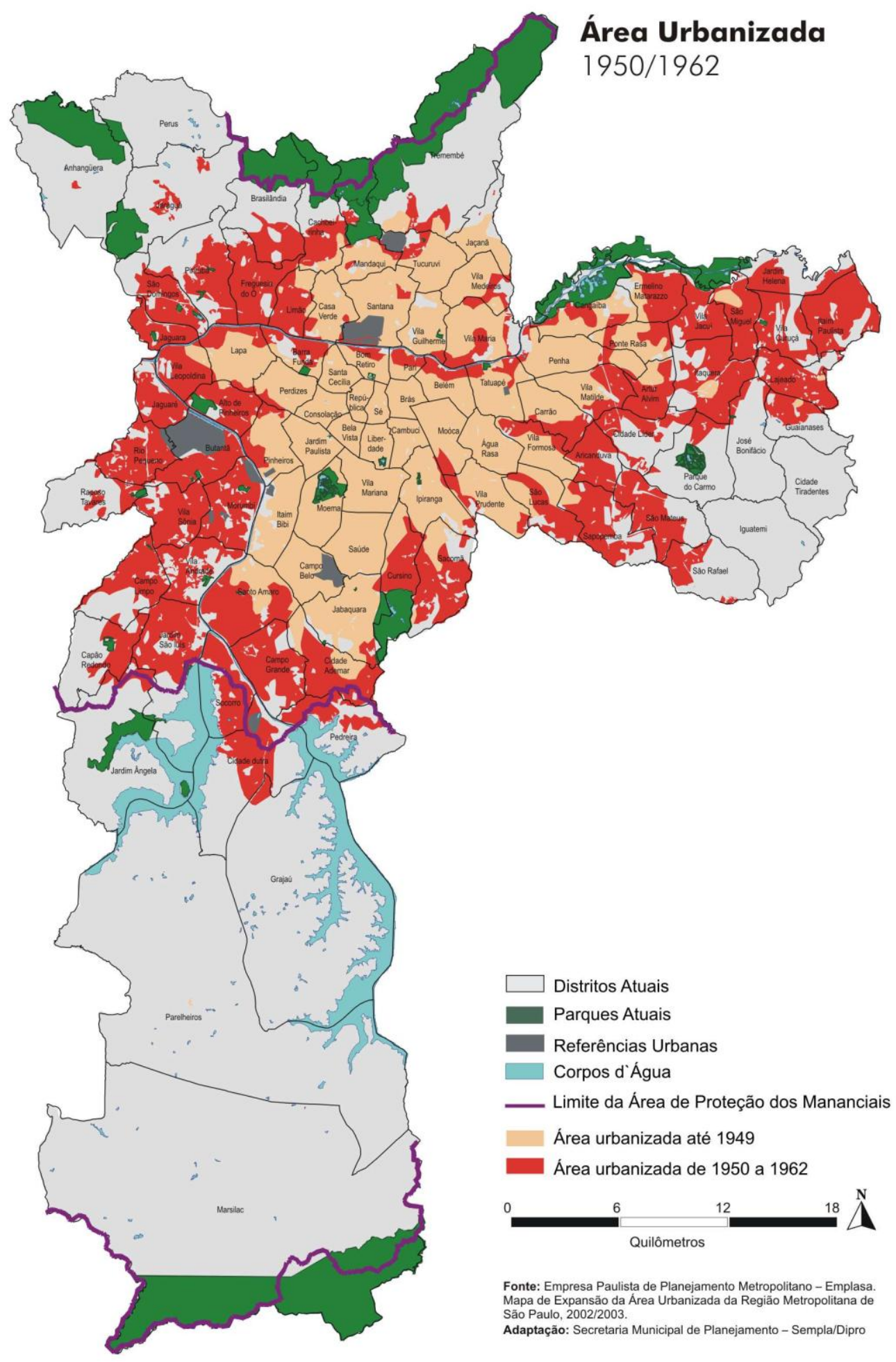

Mapa 3: Histórico demográfico do Município de São Paulo - área urbanizada 1950-1962

Fonte: http://smdu.prefeitura.sp.gov.br/historico_demografico/img/mapas/urb-1950-1960.jpg 


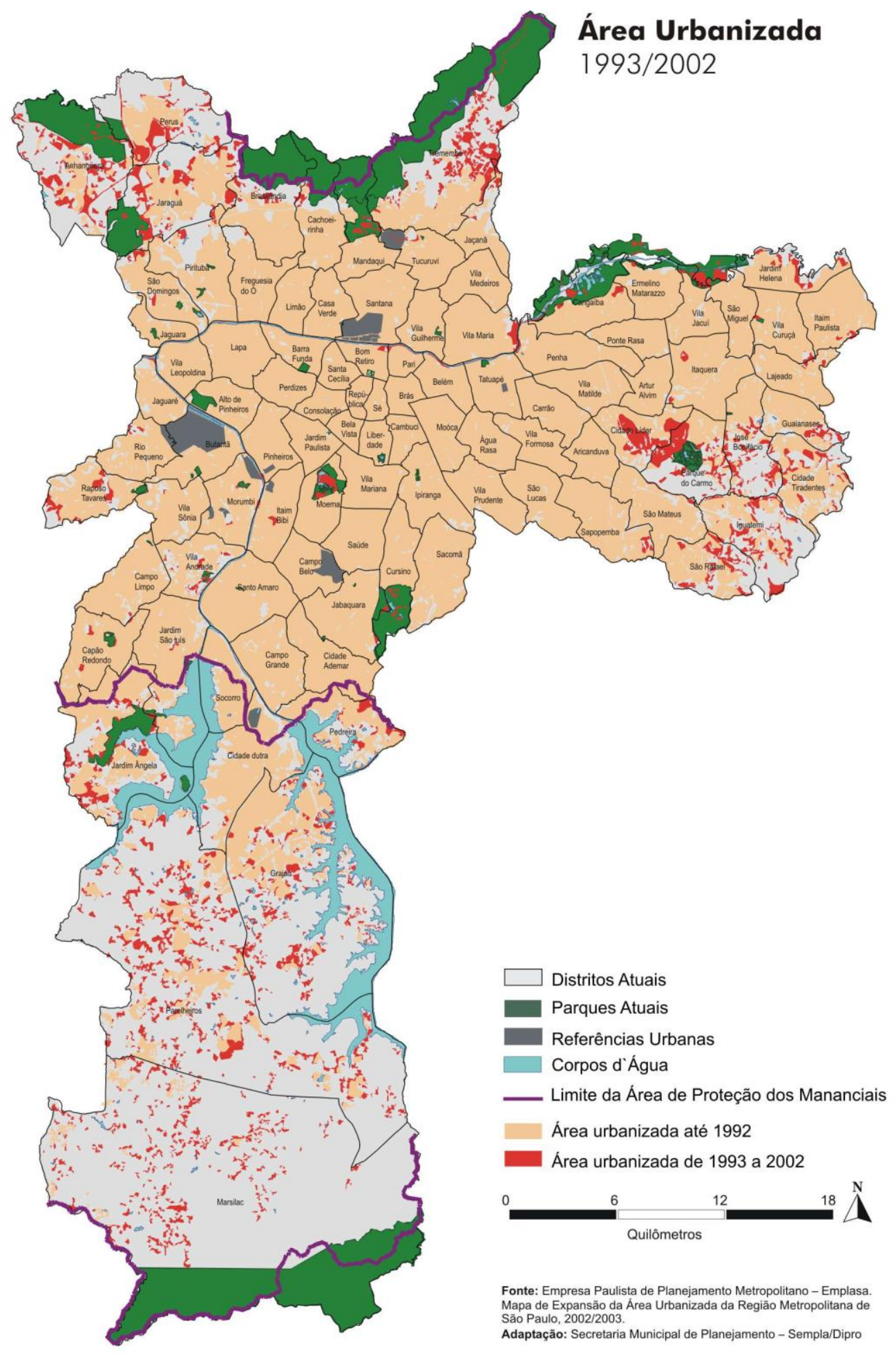

Mapa 4: Histórico demográfico do Município de São Paulo - área urbanizada 1993-2002

Fonte: http://smdu.prefeitura.sp.gov.br/historico_demografico/img/mapas/urb-2000.jpg 


\section{1. ÁREA DE ESTUDO}

A antiga favela do Real Parque com aproximadamente $47.300,00 \mathrm{~m}^{2}$ está localizada a 200 metros da Avenida Marginal do rio Pinheiros, na altura da Ponte Octávio Frias de Oliveira (Ponte Estaiada), situada no bairro do Real Parque, um dos cinco bairros que compõem o distrito do Morumbi com uma população superior a 50 mil habitantes (SEADE, 2016), na subprefeitura do Butantã. Em área contígua à favela, entre os terrenos vizinhos à Marginal e a Rua Paulo Bourroul, com frente para esta última, localiza-se o Conjunto Habitacional Real Parque (Cingapura), resultado do Programa de Verticalização de Favelas (PROVER), construído entre os anos de 1996 e 2000.

O período do início da ocupação espontânea do Real Parque data de meados da década de 1950, quando a região ainda se configurava com características rurais. Em 1987, a área já era constituída por 679 domicílios, sendo 54 em alvenaria (Censo de Favelas do Município de São Paulo, 1987). Em 1996, iniciaram-se os trabalhos de Intervenção Urbanística pela Prefeitura de São Paulo, através do PROVER (Cingapura). Dentro deste Programa, parte da área foi contemplada e, até o final do ano de 2000, foram entregues 549 unidades habitacionais, implantadas entre a Rua Paulo Bourroul e a Avenida Marginal Pinheiros.

Um estudo do IPT (Instituto de Pesquisas Teconógicas), realizado entre os anos de 2003 e 2004, identificou a favela do Real Parque como uma área de risco geológico associada a movimentos de massa, erosão, inundação e solapamento de margens de córrego (MIRANDOLA, 2003). Naquele momento, as alternativas propostas foram a remoção das moradias ameaçadas na crista e base do talude e execução de obras de drenagem e proteção superficial na encosta e/ou obras de terraplenagem, serviços de limpeza, verificação períodica das condições das obras de contenção, entre outros, para que, a partir do mapeamento elaborado, os órgãos competentes pudessem estabelecer um plano de gestão urbana para a área (MIRANDOLA, 2003).

Em 2006, a área da favela passou a ser motivo de conflitos e incertezas, com um aumento do interesse do setor imobiliário, agravado com a construção do empreendimento Shopping Cidade Jardim. A remoção de duas favelas próximas, Jardim 
Panorama e Jardim Edith, e a construção acelerada da Ponte Estaiada, muito próxima à favela, traziam preocupações aos moradores do Real Parque (NAKAMURA, 2016).

Em maio de 2008 foi realizado novo cadastramento da ocupação, totalizando 1.428 imóveis e 1.130 famílias (desconsiderando imóveis vazios e recusas de cadastro). Nesse período, também foram iniciados estudos mais completos de projeto para a área do Real Parque (ESCRITÓRIO PAULISTANO/SEHAB) ${ }^{9}$. Estes estudos apontaram que a favela do Real Parque apresentava um quadro socioeconômico grave: a maior parte da população moradora tinha apenas quatro anos de estudo e renda entre um e dois salários mínimos. O levantamento revelou também que grande parte da população residente trabalhava nas redondezas do bairro nobre do Morumbi (ESCRITÓRIO PAULISTANO/SEHAB $)^{10}$.

Em meados de 2008, as obras de reurbanização da área começaram a ser discutidas, considerando as premissas da moradia digna, que é assegurada no Brasil pelo artigo $6^{\circ}$ da Constituição Federal de 1988 (BRASIL, 1988). A proposta da Prefeitura Municipal de São Paulo de construção de prédios visava trazer melhor condição de vida aos residentes e diminuir as áreas de risco onde as moradias estavam instaladas (SEHAB/FAU, 2009).

Em maio de 2008, antes de iniciar o projeto de construção dos condomínios que substituiriam os barracos na favela do Real Parque, a prefeitura novamente fez um levantamento, apontando a existência de 1.428 domicílios (barracos) e 1.250 famílias vivendo na região (Secretaria Municipal de Habitação/SEHAB Projeto Real Parque/SP, 2009). Cabe ressaltar que os dados levantados pela SEHAB nesse momento, em relação às famílias moradoras na localidade, foram diferentes dos registrados pelo Escritório Paulistano/SEHAB. O diagnóstico também apontava a presença de áreas de alto risco, envolvendo encosta íngreme voltada para o sul e sudeste, onde os barracos eram construídos, com riscos de deslizamento, além do problema da segurança. Para além desses riscos, outros problemas foram apontados pela Prefeitura, comuns a áreas de

\footnotetext{
${ }^{9}$ Disponivel em: http://www.epaulistano.com.br/real-parque---memorial.html. Acesso em: 22 de ago. 2016.
}

${ }^{10}$ Disponivel em: http://www.epaulistano.com.br/real-parque---memorial.html. Acesso em: 22 de ago. 2016. 
ocupação irregular, como falta de infraestrutura, saneamento básico inadequado, acesso irregular à água e falta de pavimentação.

A proposta da Secretaria Municipal de Habitação foi, assim, remover totalmente as construções ali existentes e promover atendimento a todas as famílias contabilizadas. Para tanto, foi proposta a construção de edifícios verticais com até 9 pavimentos sem elevador, com construção de áreas verdes, de lazer e equipamentos de uso comunitário, sendo mantida a atividade comercial já existente na localidade. As unidades habitacionais teriam medição individual de água, luz e gás (SEHAB/FAU, 2009). Como destaca Nakamura (2016), o projeto de reurbanização do Real Parque pode ser considerado como expressão de uma mudança de diversos padrões na política de habitação do município de São Paulo. Além de uma área muito valorizada, para a realização do projeto houve a compra de dois terrenos de propriedade particular para que fossem construídas as unidades habitacionais, suficientes para contemplar todas as famílias cadastradas no Real Parque. Os terrenos vazios permitiram que fossem construídos edifícios sem que ocorressem novas remoções. Os barracos desocupados davam espaço para a construção de novos conjuntos, evitando que os moradores tivessem de ser remanejados para longe da área (NAKAMURA, 2016).

Os mapas 5 e 6 a seguir ilustram a localização da região do Real Parque, no distrito do Morumbi. A imagem 2 sinaliza a área onde foi implementado o projeto de construção dos condomínios. 


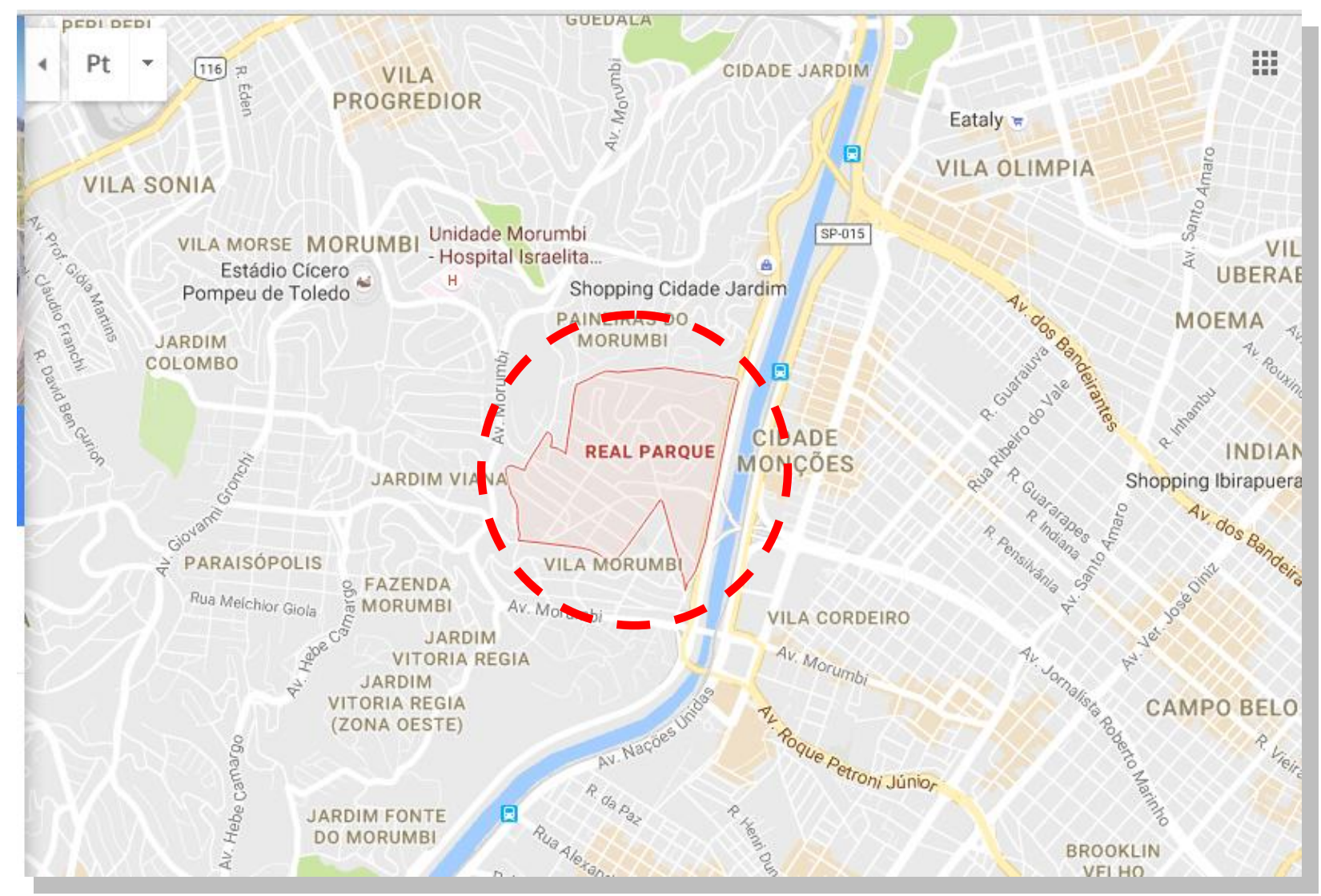

Mapa 5: Localização do Real Parque, no distrito do Morumbi

Fonte: Google Maps 


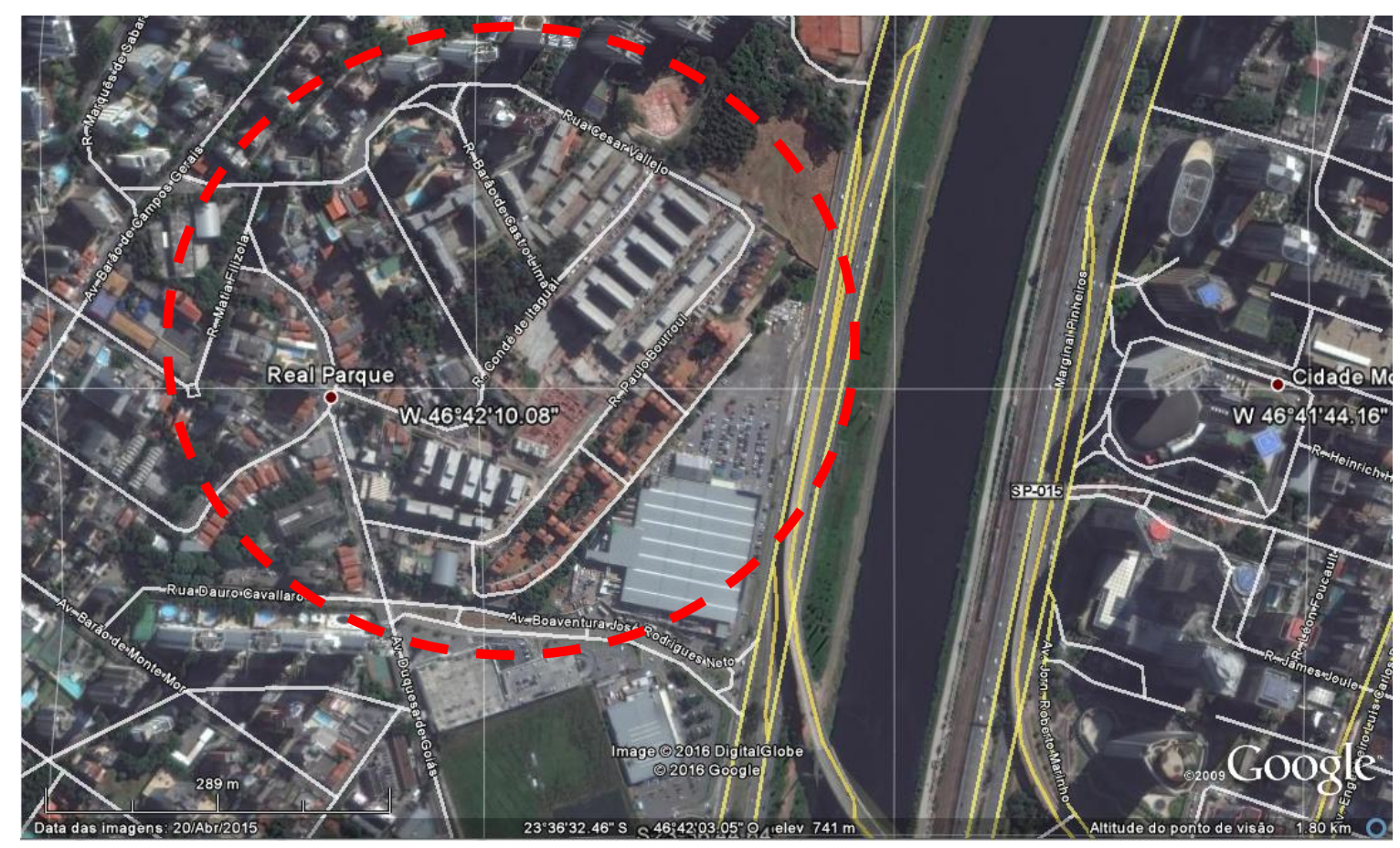

Mapa 6: Localização do Real Parque

\section{Fonte: Google Earth}

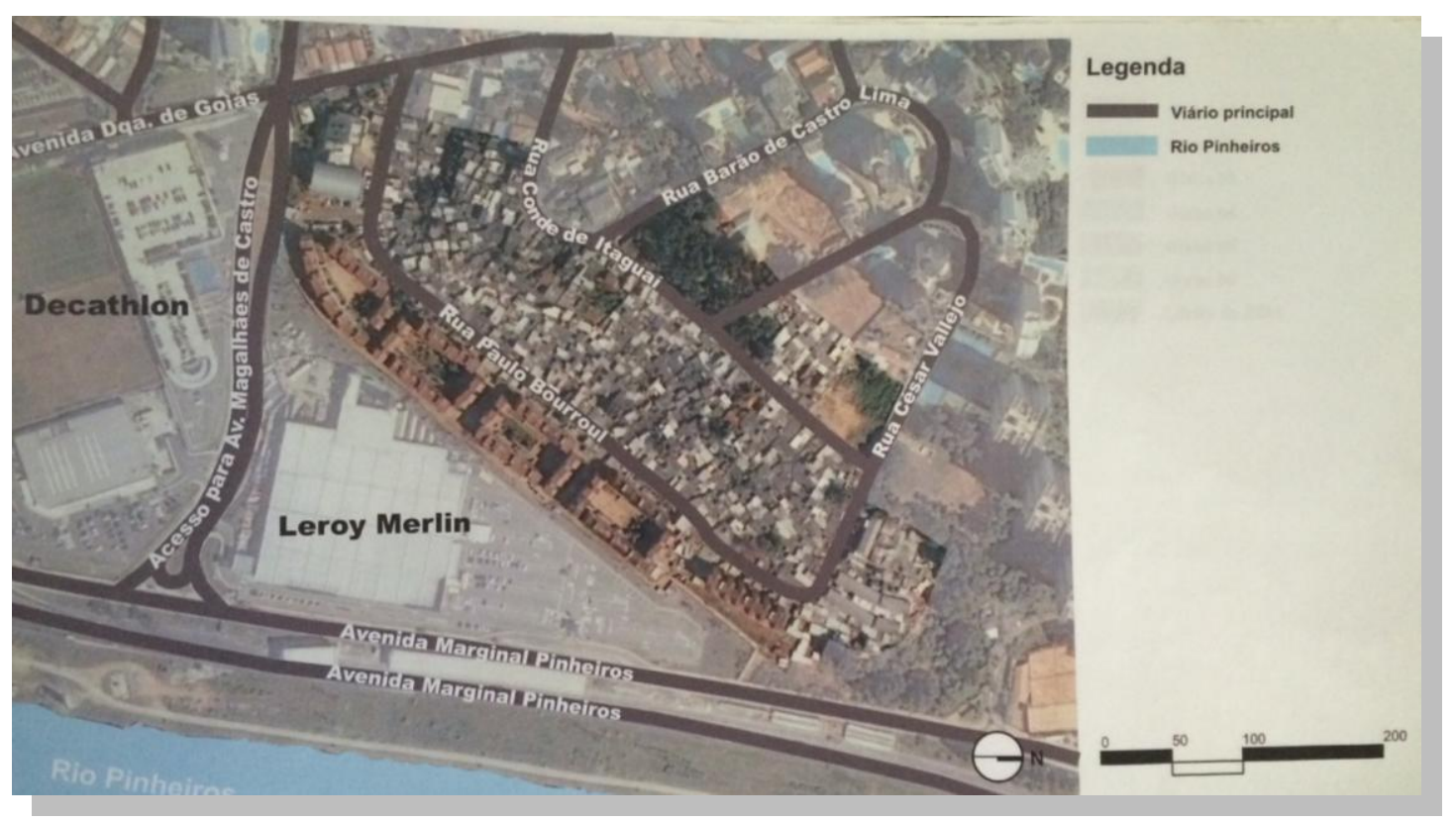

Imagem 2: Destaque da área na qual foi implementado o projeto de construção dos condomínios

Fonte: SEHAB, 2009 
Posteriormente à decisão da prefeitura, reuniões foram feitas com os moradores para apresentação do projeto e para a formação do Conselho Gestor. Em seguida, iniciou-se o processo de desapropriação da favela do Real Parque e das favelas do Panorama e Coliseu, localizadas próximo à região, no ano de 2009. Após a licitação, em 2010, a construtora OAS ficou responsável pelo projeto executivo, juntamente com estudos do Escritório Paulistano e SEHAB.

No Relatório Síntese de Caracterização, produzido em junho de 2008 pela Diagonal Urbana em parceria com a Prefeitura de São Paulo/SEHAB no Programa de Urbanização de Favelas, foram apresentados os resultados do mapeamento realizado nas áreas remanescentes da comunidade do Real Parque. O objetivo desse mapeamento foi cadastral e dividiu a comunidade em seis glebas, delimitadas por setores, viabilizando o levantamento dos domicílios e a obtenção dos dados relativos ao uso dos imóveis, tempo de moradia, composição e renda familiar, como evidencia a imagem 3.

Neste relatório, as ocupações foram definidas como imóvel, barraco, casa, sobrado ou edifício, tomando-se como parâmetros tanto critérios de convivência quanto construtivos. O que individualiza um imóvel são as condições de separação e independência. Por separação entende-se um local coberto, limitado por paredes, muros ou cercas. Por independência entende-se o acesso direto ao local de moradia, sem passar pelo interior de outro imóvel. Já os domicílios foram caracterizados como local habitual de residência e local de habitação coberto, limitado por paredes e/ou cortinas que permite a uma pessoa, ou um grupo de pessoas, se isolarem das demais com a finalidade de dormir, preparar ou consumir alimentos. $\mathrm{O}$ acesso direto ao local de moradia, sem passar pela habitação de outras pessoas, permite caracterizar cada unidade e vinculá-la às pessoas que nela residem. As unidades mistas são aquelas edificações utilizadas simultaneamente para a função de habitação e para a prática de atividade econômica, formal ou não (PREFEITURA DA CIDADE DE SÃO PAULO/DIAGONAL URBANA, 2008). 


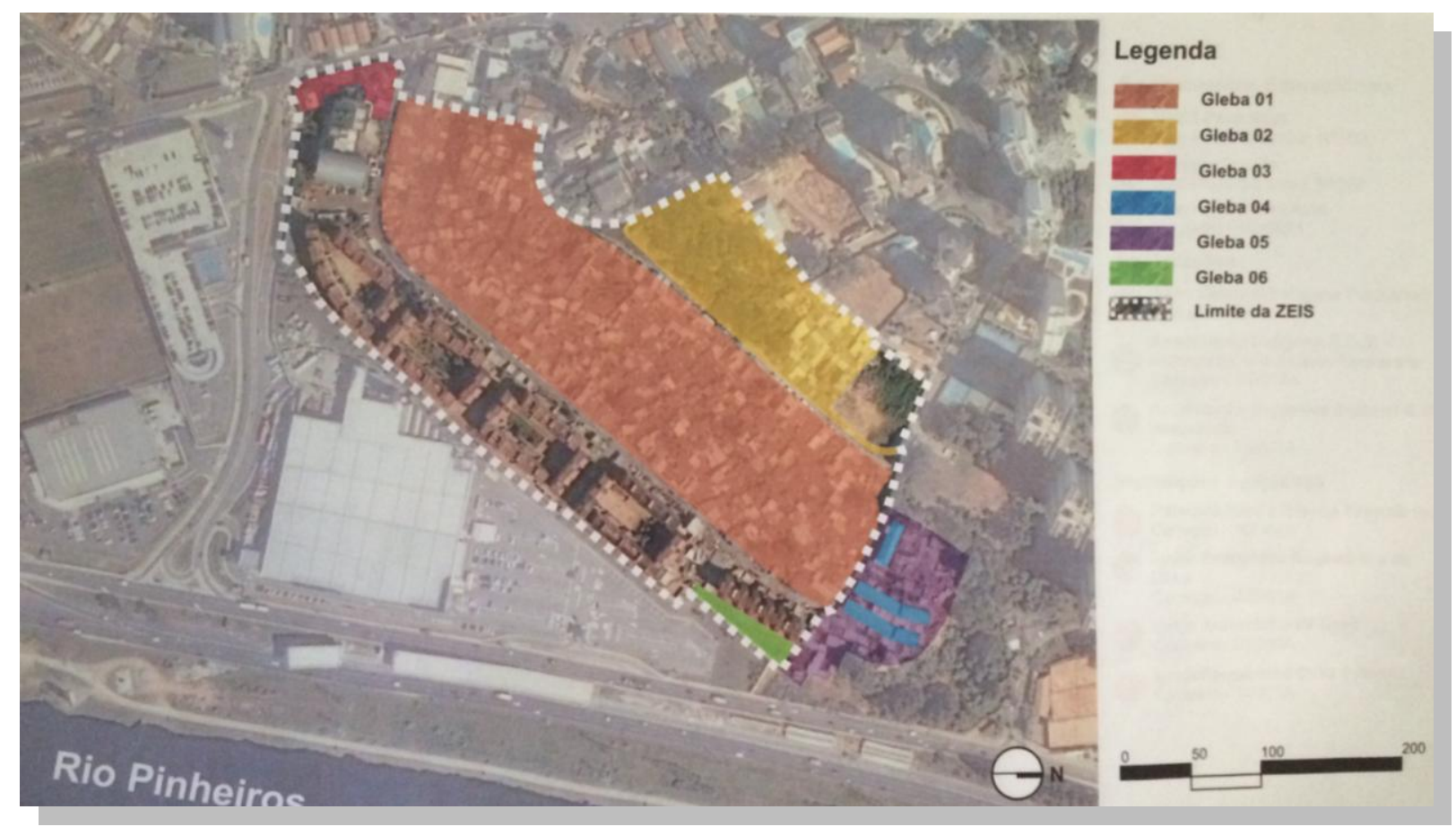

Imagem 3: Mapa com os limites das glebas

Fonte: SEHAB, 2009

As informações no Relatório Síntese de Caracterização foram sistematizadas de acordo com os indicadores avaliados: dados gerais da área, incluindo situação habitacional, tempo de moradia, composição e renda familiar; e dados específicos por gleba - Glebas de 1 a 6, abrangendo os mesmos indicadores citados. Esses dados delinearam o projeto proposto pela prefeitura de São Paulo com a construção de condomínios como ilustram a imagem 4 (referente à fase de elaboração do projeto) e a foto 4, com parte dos condomínios já construída. 


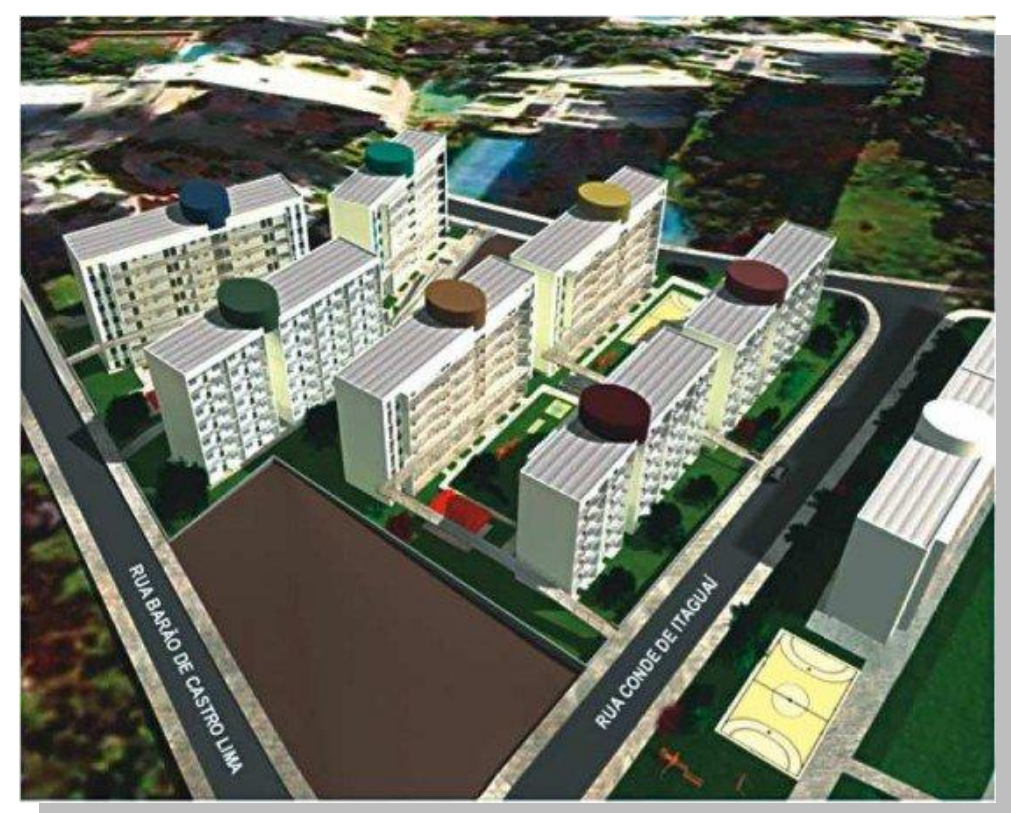

Imagem 4: Imagem do projeto de substituição dos barracos existentes por conjuntos habitacionais, em um total de 1.135 apartamentos

Fonte: Veja São Paulo, 2011 (Disponível em: http://vejasp.abril.com.br/materia/revitalizacaoda-favela-real-parque-esta-em-xeque

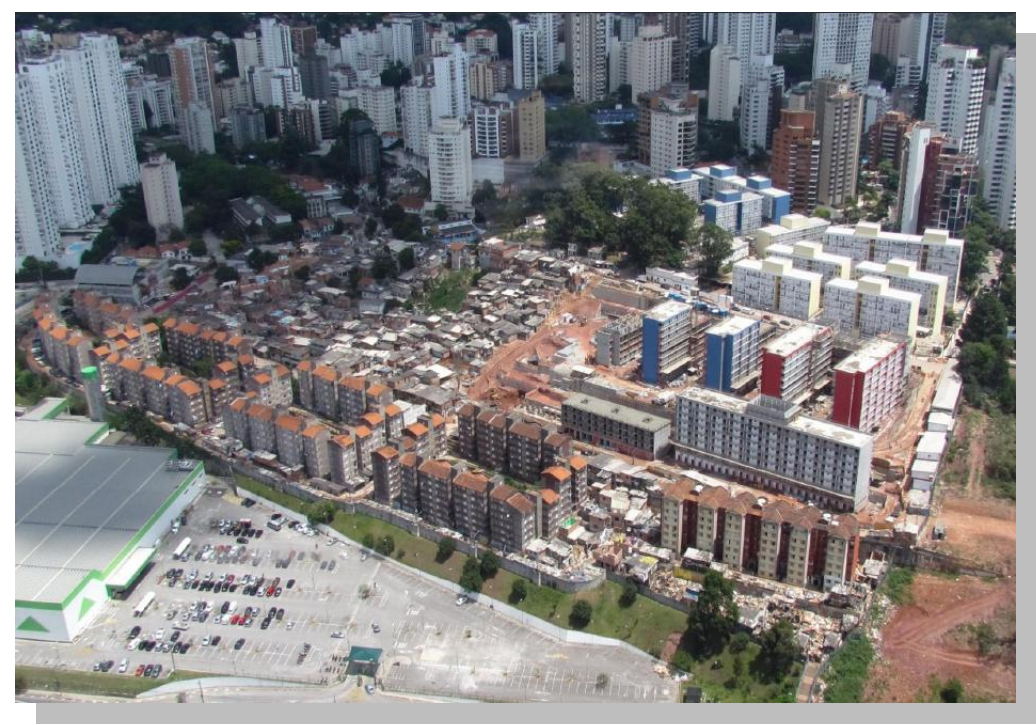

Foto 4: Foto aérea do Real Parque após a construção dos condomínios (à direita)

Fonte: SEHAB, 2009

Cabe ressaltar que os dados do Relatório Síntese de Caracterização, desenvolvido pela Diagonal Urbana/SEHAB, também destoam dos levantamentos 
anteriores, apontando 1.430 imóveis registrados em 2008 e 1.110 famílias. Desse total de imóveis, 1.078 foram classificados como imóveis de uso residencial $(75,38 \%)$ e 32 $(2,24 \%)$ de uso misto, ou seja, os ocupantes utilizavam parte do imóvel para pequenos comércios, como mostra a Tabela 1. Esses dados mostram que havia um predomínio de ocupações apenas para moradias, sem o uso misto para pequenos comércios. Os dados do relatório também serviram de base para identificação dos equipamentos educacionais, associações e instituições religiosas existentes na região, como ilustra a imagem 5.

\begin{tabular}{|c|c|c|}
\hline TIPOS DE USO & NÚMERO ABSOLUTO & $\%$ \\
\hline Residencial & 1078 & $75,38 \%$ \\
\hline Misto & 32 & $2,24 \%$ \\
\hline Comércio & 82 & $5,73 \%$ \\
\hline Construção & 1 & $0,07 \%$ \\
\hline Em construção & 25 & $1,75 \%$ \\
\hline Igreja & 4 & $0,28 \%$ \\
\hline Instituição & 4 & $0,28 \%$ \\
\hline Morador ausente & 102 & $7,13 \%$ \\
\hline Recusa & 55 & $3,85 \%$ \\
\hline Serviços & 15 & $1,05 \%$ \\
\hline Vazio & 32 & $2,24 \%$ \\
\hline TOTAL GERAL & $\mathbf{1 4 3 0}$ & $\mathbf{1 0 0 , 0 0 \%}$ \\
\hline
\end{tabular}

Tabela 1: Situação habitacional em 2008

Fonte: Relatório Síntese de caracterização, Diagonal/SEHAB, 2008 


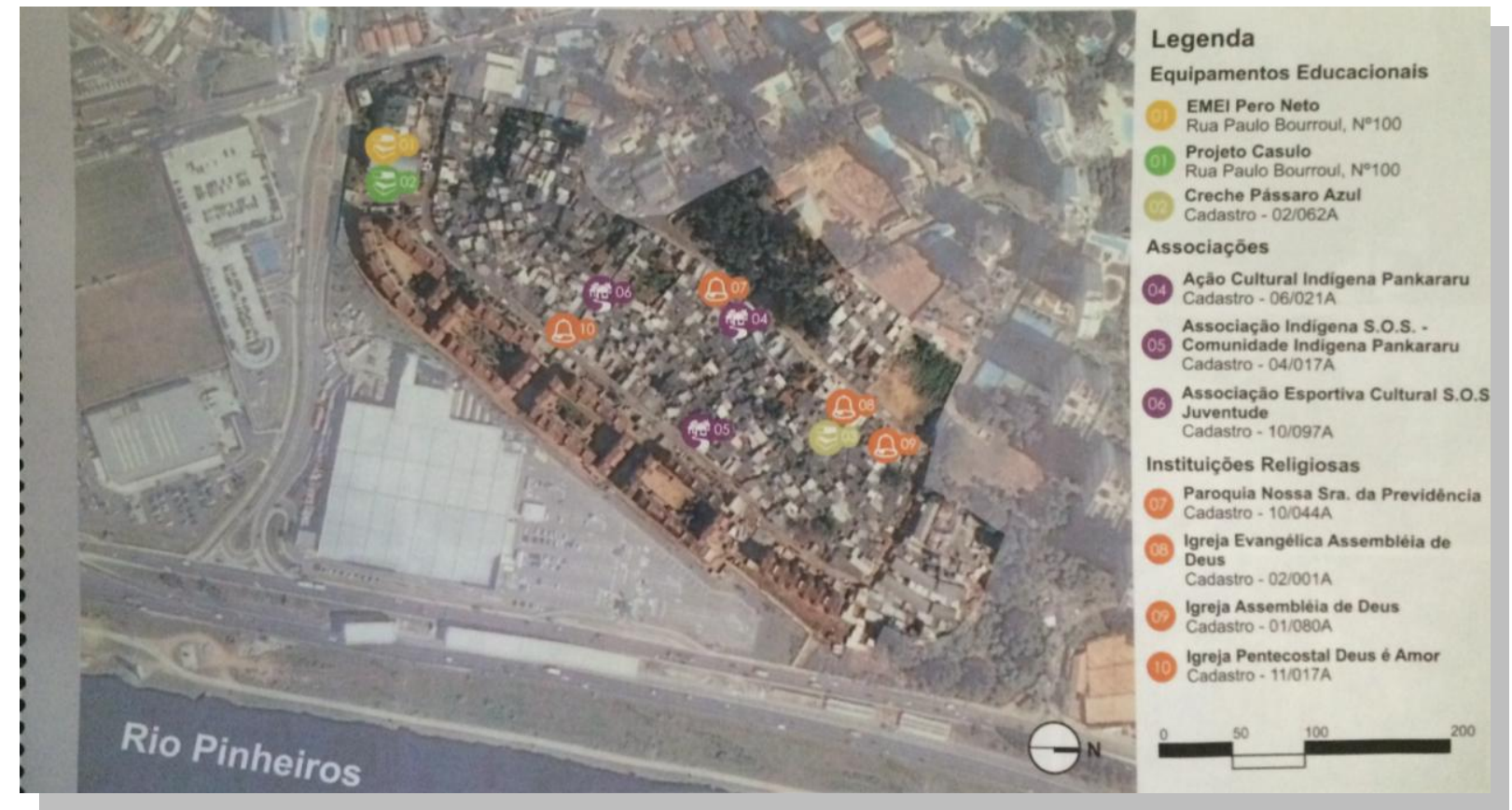

Imagem 5: Mapeamento das instituições existentes na região

Fonte: SEHAB, 2009

Os dados do Relatório Síntese de Caracterização (Diagonal/SEHAB, 2008) mostram que 235 famílias viviam há mais de 15 anos no imóvel, correspondendo a $21,17 \%$ do total de famílias registradas naquele momento; 412 famílias $(37,12 \%)$ informaram como período de ocupação do domicílio de um a cinco anos, como mostra a Tabela 2.

\begin{tabular}{|c|c|c|}
\hline FAIXA DE TEMPO & NÚMERO ABSOLUTO & $\%$ \\
\hline Sem informação & 8 & $0,72 \%$ \\
\hline Menos de 1 ano & 83 & $7,48 \%$ \\
\hline De 1 a 3 anos & 202 & $18,20 \%$ \\
\hline De 3 a 5 anos & 210 & $18,92 \%$ \\
\hline De 5 a 10 anos & 180 & $16,22 \%$ \\
\hline De 10 a 15 anos & 192 & $17,30 \%$ \\
\hline Mais de 15 anos & 235 & $21,17 \%$ \\
\hline TOTAL GERAL & $\mathbf{1 1 1 0}$ & $\mathbf{1 0 0 , 0 0 \%}$ \\
\hline
\end{tabular}

Tabela 2: Tempo de moradia

Fonte: Relatório Síntese de caracterização, Diagonal/SEHAB, 2008 
Observa-se que $60 \%$ das famílias registradas apresentavam entre um e três membros em sua composição. As demais, representando os outros $40 \%$ do universo pesquisado, eram famílias mais numerosas, compostas por quatro a nove integrantes $(38,92 \%)$ e acima de dez $(1,08 \%)$, conforme dados da Tabela 3.

\begin{tabular}{|c|c|c|}
\hline QUANTIDADE DE PESSOAS & NÚMERO ABSOLUTO & $\%$ \\
\hline 1 & 203 & $18,29 \%$ \\
\hline 2 & 221 & $19,91 \%$ \\
\hline 3 & 242 & $21,80 \%$ \\
\hline 4 & 175 & $15,77 \%$ \\
\hline 5 & 143 & $12,88 \%$ \\
\hline 6 & 60 & $5,41 \%$ \\
\hline 7 & 31 & $2,79 \%$ \\
\hline 8 & 13 & $1,17 \%$ \\
\hline 9 & 10 & $0,90 \%$ \\
\hline 10 & 4 & $0,36 \%$ \\
\hline 11 & 3 & $0,27 \%$ \\
\hline 12 & 3 & $0,27 \%$ \\
\hline 14 & 1 & $0,09 \%$ \\
\hline 17 & 1 & $\mathbf{1 0 0 , 0 0 \%}$ \\
\hline TOTAL GERAL & $\mathbf{1 1 1 0}$ & \\
\hline
\end{tabular}

Tabela 3: Composição familiar

\section{Fonte: Relatório Síntese de caracterização, Diagonal/SEHAB, 2008}

Para cálculo da composição da renda, o relatório considerou a coleta de dados declarados pelos entrevistados referentes ao rendimento de cada morador do domicílio, o que possibilitou transformar a soma desses rendimentos em salários mínimos da época da pesquisa $($ maio/2008 $=\mathrm{R} \$ 415,00$ ). Conforme se observa na tabela 4 , a maior concentração de renda entre as famílias pesquisadas estava na faixa entre 1 e 3 salários mínimos, abrangendo 702 famílias $(63,24 \%)$. 


\begin{tabular}{|c|c|c|}
\hline FAIXA DE RENDA & NÚMERO ABSOLUTO & $\%$ \\
\hline Sem renda & 34 & $3,06 \%$ \\
\hline Até 1 salário mínimo & 168 & $15,14 \%$ \\
\hline Entre 1 e 2 salários mínimos & 440 & $39,64 \%$ \\
\hline Entre 2 e 3 salários mínimos & 262 & $23,60 \%$ \\
\hline Entre 3 e 4 salários mínimos & 106 & $9,55 \%$ \\
\hline Entre 4 e 5 salários mínimos & 53 & $4,77 \%$ \\
\hline Mais que 5 salários mínimos & 47 & $4,23 \%$ \\
\hline TOTAL GERAL & $\mathbf{1 1 1 0}$ & $\mathbf{1 0 0 , 0 0 \%}$ \\
\hline
\end{tabular}

Tabela 4: Renda familiar

\section{Fonte: Relatório Síntese de caracterização, Diagonal/SEHAB, 2008}

Ainda para compreender as características da comunidade afetada pelo processo de reurbanização, vale recorrer aos dados levantados, naquele mesmo período, por um estudo realizado pelo Observatório Social do Projeto Casulo na localidade, no ano de 2004. O estudo evidenciava alguns dos problemas sócioeconomicos destacados naquela época pelos moradores entrevistados. A pesquisa feita contemplou a aplicação de questionários à população de jovens da favela do Real Parque (amostra de 455 jovens) e constatou que para $17 \%$ deles o maior problema estava relacionado ao emprego. Outros problemas também foram reconhecidos pelos entrevistados, como sistematizados na tabela 5. Os destaques estavam relacionados à condição de emprego e drogas na comunidade, seguidos por saúde e limpeza pública. Naquele momento, e considerando os dados da pesquisa, é possível observar que a questão da moradia em si não era apontada como um dos principais problemas. 


\begin{tabular}{|c|c|}
\hline PRINCIPAIS PROBLEMAS & NÚMERO DE RESPOSTAS EM \% \\
\hline Emprego & 17 \\
\hline Drogas & 15 \\
\hline Segurança & 11 \\
\hline Saúde & 10 \\
\hline Limpeza pública & 09 \\
\hline Habitação & 09 \\
\hline Álcool & 08 \\
\hline Lazer & 08 \\
\hline Transporte & 06 \\
\hline Escola & 06 \\
\hline
\end{tabular}

Tabela 5: Resultados da pesquisa conduzida pelo Projeto Casulo em 2004 sobre problemas socioeconômicos na localidade

Fonte: ICE - INSTITUTO DE CIDADANIA EMPRESARIAL. (Disponível em: http://ice.org.br/projeto-casulo/)

O Projeto Casulo, em parceria com o Instituto de Cidadania Empresarial, também havia realizado uma pesquisa em 2004, identificando naquele momento 821 unidades domiciliares no espaço denominado favela, 63 moradias em um alojamento da Prefeitura e 489 apartamentos nos condomínios do Cingapura, totalizando 1.373 residências na comunidade do Real Parque. Desse total, foram entrevistados 1.116 responsáveis pelo domicílio. Somando os responsáveis entrevistados e o número de dependentes nesses domicílios, a pesquisa identificou na comunidade Real Parque um total de 4.314 moradores ${ }^{11}$. A pesquisa identificou o perfil socioeconômico da comunidade, seus costumes, saberes, habilidades, sonhos, desejos e percepções de moradores.

Os resultados daquele estudo mostravam que a maior parte dos moradores da comunidade era proveniente do Nordeste, especialmente de Pernambuco e Bahia. Do

${ }^{11}$ ICE - INSTITUTO DE CIDADANIA EMPRESARIAL. A pesquisa foi realizada no ano de 2004 em parceria com o Projeto Casulo. Disponivel em: http://ice.org.br/projeto-casulo/. Acesso em: 12 de set. 2016. 
total de entrevistados, havia predomínio de moradores com o nível de ensino fundamental (72\%), 16\% se declararam não alfabetizados, $11 \%$ com Ensino Médio e 1\% com Ensino Universitário. Em 2004, a maior parte dos moradores responsáveis por seus domicílios estava empregada (63\%).

Quanto ao tipo de moradia, 59\% declararam viver em favela, 36\% em conjunto habitacional e 5\% em alojamento. A média de moradores por domicílio era de 3,9 pessoas. Num comparativo com dados do IBGE no Censo de 2000, observa-se que a média no Distrito do Morumbi era de 3,5 pessoas e da cidade de São Paulo de 3,4 pessoas.

A pesquisa realizada pelo Projeto Casulo apontou que, para os moradores, naquele momento, para além da existência do próprio Projeto Casulo na localidade, outros aspectos eram considerados como qualidades positivas do Real Parque, como educação e posto de saúde. Quanto à participação social comunitária, a pesquisa revelou que $26 \%$ dos entrevistados tinham alguém da família envolvido em algum tipo de participação social; $73 \%$ afirmavam não ter familiares envolvidos nestes tipos de projetos. Os principais locais de participação comunitária citados foram o Projeto Casulo, associação de moradores, centro comunitário, escola, igreja e comunidade Pankararu. A pesquisa ainda trouxe dados sobre percepções acerca da responsabilidade pela resolução dos problemas da comunidade: $48 \%$ apontavam que era a própria comunidade, $40 \%$ o poder público, $10 \%$ reconheciam que as soluções seriam de cunho individual. $^{12}$

\footnotetext{
${ }^{12}$ Quando procurados no âmbito deste estudo, os colaboradores do Projeto Casulo disponibilizaram somente os dados mais antigos, antes do processo de reurbanização. $E$ válido ressaltar que a falta de dados mais recentes, como estes levantados nestas pesquisas citadas, foi evidenciada também pelos moradores durante suas entrevistas. Eles destacaram que as pesquisas feitas datam dos anos anteriores ao processo de reurbanização, entre $2004 \mathrm{e}$ 2008.
} 


\subsection{OS EFEITOS DO PROJETO DE REURBANIZAÇÃO}

Nakamura (2016), ao fazer uma análise do projeto de reurbanização do Real Parque, argumenta que este projeto expressa as mudanças de padrões na política habitacional da cidade de São Paulo, com a localização de empreendimento em área valorizada, construção de unidades habitacionais que contemplem todas as famílias cadastradas, desapropriação de terrenos na área para construção de edifícios evitando novas remoções de moradores e melhora da qualidade dos conjuntos em relação ao projeto anterior, o Cingapura. Ao envolver um processo de organização do conselho gestor da Zona Especial de Interesse Social (ZEIS) do Real Parque, o projeto propiciou envolvimento de moradores e associações que os representam. Contudo, para este pesquisador, essa participação foi prioritariamente forte na tentativa de defender a máxima ocupação do terreno, se alinhando ao mercado imobiliário na produção infinita de propriedade.

Na sua perspectiva, verticalização e homogeneização - características do projeto do Real Parque - foram diretrizes determinadas tanto pelas condições gerais do projeto, como defendidas pela população atendida, que desde o início se mostrou favorável e exigiu a construção de apartamentos iguais, com mesma quantidade de dormitórios, independentemente do número de indivíduos nas famílias contempladas. Ao analisar o empreendimento e suas características estéticas e arquitetônicas, o pesquisador destaca sua inserção na política de promoção de moradia de São Paulo e aponta seus conjuntos habitacionais, caracterizados pela fachada e implantação, como marcantes na paisagem - dando visibilidade, inclusive, as ações efetuadas pelo governo municipal (NAKAMURA, 2016).

Rezende (2015), que também se debruçou em estudo sobre o projeto de reurbanização da favela do Real Parque, endossa essas observações, destacando que a urbanização proposta, ainda que possibilite o acesso dos moradores à infraestrutura e serviços da cidade, não se realiza com a mesma qualidade e frequência para todos. Ao término do projeto de reurbanização, a pesquisadora ainda chama atenção para o fato de que o processo de requalificação urbana permitiu uma valorização imobiliária da área, o que, associado à inexistência ou inadequação de instrumentos efetivos que garantam a 
inserção e permanência dos moradores no núcleo urbanizado, tem induzido a expulsão de famílias mais vulneráveis para outras localidades (REZENDE, 2015). 


\section{CAPÍTULO 2: ABORDAGEM METODOLÓGICA}

A partir de pesquisa exploratória, baseada no estudo do caso Real Parque, e dentro de uma perspectiva qualitativa e afiliada ao campo da Geografia ${ }^{13}$, o estudo realizado envolveu revisão bibliográfica sobre os temas que compõem o escopo do objeto desta pesquisa, pesquisa documental, observação, realização de entrevistas e grupos focais, registros visuais e análise dos dados, como será descrito adiante.

O estudo de caso visa conhecer em profundidade o como e o porquê de uma determinada situação, procurando descobrir o que há nela de mais essencial e característico (FONSECA, 2002). A pesquisa qualitativa trabalha com o universo de significados, motivos, aspirações, crenças, valores e atitudes, o que corresponde a um espaço mais profundo dado às relações, processos e fenômenos que não podem ser reduzidos à operacionalização de variáveis (MINAYO, 2001; GERHARDT, SILVEIRA, 2009).

Por meio de pesquisa documental, foram levantados dados e documentos com o objetivo de compreender a região estudada e o processo de reurbanização. Para a realização da pesquisa empírica foram estabelecidos contatos e aproximações com os moradores da área estudada, entre 2015 e 2016, sendo a primeira visita realizada pelo pesquisador em outubro de 2015, dando continuidade aos estudos que já haviam sido iniciados na região, no âmbito do Projeto financiado pela Fapesp. Esta visita teve como objetivo conhecer o processo de reurbanização da área e estabelecer contatos com moradores. Ao longo de 2016, foram realizadas observações de três reuniões com moradores da comunidade, oito entrevistas individuais e dois grupos focais, um misto (envolvendo mães de família, chefes do lar, lideranças da comunidade, moradores mais antigos e mais recentes) e um com jovens (como descritos nas tabelas 6, 7, 8 e 9 a seguir).

\footnotetext{
${ }^{13}$ A geografia é uma ciência de síntese, na qual (...) “aos fatos tomados de empréstimo de diversas ciências, cabe à geografia reagrupá-los, ordená-los segundo as exigências de sua intenção dominante, que é de nunca se afastar da realidade tal como ela se oferece, no que ela tem de global e de concreto. Reagrupados os elementos, a geografia traçará um quadro racional e coerente, em que a impressão direta é confirmada pela reflexão” (DARDEL, 2011, p. 87).
} 


\begin{tabular}{|c|c|c|}
\hline PARTICIPANTES & $\begin{array}{c}\text { IDADE APROXIMADA/ } \\
\text { OCUPAÇÃO }\end{array}$ & $\begin{array}{c}\text { TEMPO DE } \\
\text { REAL } \\
\text { PARQUE }\end{array}$ \\
\hline $\mathbf{1}^{\mathbf{a}}$ Reunião - Morador 1 & $\begin{array}{c}45 \text { anos / Síndica de um dos } \\
\text { condomínios, trabalha }\end{array}$ & 26 anos \\
\hline $\mathbf{1}^{\mathbf{a}}$ Reunião - Morador 2 & $\begin{array}{c}23 \text { anos / Estudante universitária, } \\
\text { participa ativamente das reuniões } \\
\text { dos moradores }\end{array}$ & 23 anos \\
\hline $\mathbf{1}^{\mathbf{a}}$ Reunião - Morador 3 & $\begin{array}{c}33 \text { anos / Subsíndico de um dos } \\
\text { condomínios / Trabalha fora do Real }\end{array}$ & Mais de 25 \\
& Parque \\
\hline $\mathbf{2}^{\mathbf{a}}$ Reunião - Morador 4 & $\begin{array}{c}45 \text { anos / Síndica de um dos } \\
\text { condomínios, trabalha }\end{array}$ & 26 anos \\
\hline $\mathbf{2}^{\mathbf{a}}$ Reunião - Morador 5 & 65 anos / Aposentado & Mais de 50 \\
\hline $\mathbf{3}^{\mathbf{a}}$ Reunião - Morador $\mathbf{6}$ & $\begin{array}{c}28 \text { anos / Participa dos Projetos do } \\
\text { Casulo, desempregado }\end{array}$ & Mais de 20 \\
\hline
\end{tabular}

Tabela 6: Reuniões com moradores da comunidade (três reuniões ao longo de 2015 e 2016) 


\begin{tabular}{|c|c|c|}
\hline PARTICIPANTES & $\begin{array}{l}\text { IDADE APROXIMADA/ } \\
\text { OCUPAÇÃO }\end{array}$ & $\begin{array}{l}\text { TEMPO DE } \\
\text { REAL } \\
\text { PARQUE }\end{array}$ \\
\hline Morador 1 - individual & $\begin{array}{c}35 \text { anos / Síndico de um dos } \\
\text { condomínios, trabalha fora do Real } \\
\text { Parque }\end{array}$ & $\begin{array}{c}\text { Mais de } 15 \\
\text { anos }\end{array}$ \\
\hline Morador 2 - individual & $\begin{array}{l}23 \text { anos / Estudante universitária, } \\
\text { participa ativamente das reuniões } \\
\text { dos moradores }\end{array}$ & 23 anos \\
\hline Morador 3 - individual & $\begin{array}{l}48 \text { anos / Síndico de um dos } \\
\text { condomínios, realiza trabalhos não } \\
\text { remunerados no Real Parque }\end{array}$ & $\begin{array}{c}\text { Mais de } 30 \\
\text { anos }\end{array}$ \\
\hline Morador 4 - individual & $\begin{array}{c}65 \text { anos / Morador influente no Real } \\
\text { Parque, um dos mais antigos. } \\
\text { Aposentado }\end{array}$ & $\begin{array}{c}\text { Mais de } 40 \\
\text { anos }\end{array}$ \\
\hline Morador 5 - individual & $\begin{array}{c}16 \text { anos / Estudante, participa do } \\
\text { grupo de dança }\end{array}$ & 16 anos \\
\hline Morador 6 - individual & $\begin{array}{c}16 \text { anos / Estudante, participa do } \\
\text { grupo de dança }\end{array}$ & 16 anos \\
\hline Morador 7 - individual & 45 anos / Dona de casa & $\begin{array}{l}\text { Mais de } 30 \\
\text { anos }\end{array}$ \\
\hline Morador 8 - individual & 50 anos / Desempregado & $\begin{array}{l}\text { Mais de } 40 \\
\text { anos }\end{array}$ \\
\hline
\end{tabular}

Tabela 7: Entrevistas individuais (entrevistas realizadas ao longo de 2015 e 2016) 


\begin{tabular}{|c|c|c|}
\hline PARTICIPANTES & $\begin{array}{l}\text { IDADE APROXIMADA/ } \\
\text { OCUPAÇÃO }\end{array}$ & $\begin{array}{l}\text { TEMPO DE } \\
\text { REAL } \\
\text { PARQUE }\end{array}$ \\
\hline Morador 1 - grupo misto & $\begin{array}{c}50 \text { anos / Dona de casa, } \\
\text { desempregada e faz "bicos" }\end{array}$ & $\begin{array}{l}\text { Mais de } 20 \\
\text { anos }\end{array}$ \\
\hline Morador 2 - grupo misto & $\begin{array}{c}50 \text { anos / Representante de um dos } \\
\text { síndicos, desempregada }\end{array}$ & $\begin{array}{l}\text { Mais de } 40 \\
\text { anos }\end{array}$ \\
\hline Morador 3 - grupo misto & $\begin{array}{c}60 \text { anos / Desempregada, dona de } \\
\text { casa }\end{array}$ & $\begin{array}{l}\text { Mais de } 40 \\
\text { anos }\end{array}$ \\
\hline Morador 4 - grupo misto & $\begin{array}{c}35 \text { anos / Síndico de um dos } \\
\text { condomínios / Trabalha fora do Real } \\
\text { Parque }\end{array}$ & $\begin{array}{l}\text { Mais de } 10 \\
\text { anos }\end{array}$ \\
\hline Morador 5 - grupo misto & $\begin{array}{l}65 \text { anos / Mãe e representante de um } \\
\text { subsíndico de um dos condomínios, } \\
\text { aposentada }\end{array}$ & $\begin{array}{c}\text { Mais de } 30 \\
\text { anos }\end{array}$ \\
\hline Morador 6 - grupo misto & $\begin{array}{c}35 \text { anos / Trabalha fora do Real } \\
\text { Parque }\end{array}$ & 20 anos \\
\hline Morador 7 - grupo misto & $\begin{array}{c}50 \text { anos / Moradora do antigo } \\
\text { Cingapura, desempregada }\end{array}$ & 40 anos \\
\hline Morador 8 - grupo misto & $\begin{array}{c}50 \text { anos / Trabalha no Real Parque, } \\
\text { promove trabalhos com jovens }\end{array}$ & 6 anos \\
\hline Morador 9 - grupo misto & $\begin{array}{c}26 \text { anos / Trabalha fora do Real } \\
\text { Parque, participa do grupo de música } \\
\text { e dança }\end{array}$ & 26 anos \\
\hline Morador 10 - grupo misto & $\begin{array}{c}55 \text { anos / Síndica de um dos } \\
\text { condomínios, trabalha fora do Real } \\
\text { Parque }\end{array}$ & 26 anos \\
\hline Morador 11 - grupo misto & 30 anos / Diarista desempregada & 20 anos \\
\hline
\end{tabular}

Tabela 8: Grupo focal misto (grupo focal misto realizado em 10 de Jul. 2016) 


\begin{tabular}{|c|c|c|}
\hline ENTREVISTADOS & $\begin{array}{l}\text { IDADE APROXIMADA/ } \\
\text { OCUPAÇÃO }\end{array}$ & $\begin{array}{c}\text { TEMPO DE } \\
\text { REAL } \\
\text { PARQUE }\end{array}$ \\
\hline Morador 1 - grupo jovens & $\begin{array}{l}15 \text { anos / Estudante, participa do } \\
\text { grupo de dança e Projeto Casulo }\end{array}$ & 15 anos \\
\hline Morador 2 - grupo jovens & $\begin{array}{c}24 \text { anos / Administradora de } \\
\text { empresas, tem comércio no Real } \\
\text { Parque }\end{array}$ & 17 anos \\
\hline Morador 3 - grupo jovens & $\begin{array}{l}17 \text { anos / Estudante e trabalha fora } \\
\text { do Real Parque }\end{array}$ & 17 anos \\
\hline Morador 4 - grupo jovens & $\begin{array}{c}19 \text { anos / Estudante, participa do } \\
\text { grupo de dança e trabalha fora do } \\
\text { Real Parque }\end{array}$ & 18 anos \\
\hline Morador 5 - grupo jovens & $\begin{array}{c}17 \text { anos / Estudante, participa do } \\
\text { grupo de dança }\end{array}$ & 4 anos \\
\hline Morador 6 - grupo jovens & 12 anos / Estudante & 3 anos \\
\hline Morador 7 - grupo jovens & 13 anos / Estudante & 2 anos \\
\hline Morador 8 - grupo jovens & 10 anos / Estudante & 5 anos \\
\hline Morador 9 - grupo jovens & 10 anos / Estudante & 1 ano \\
\hline $\begin{array}{l}\text { Morador } 10 \text { - grupo } \\
\text { jovens }\end{array}$ & $\begin{array}{c}16 \text { anos / Estudante, participa do } \\
\text { Projeto Casulo }\end{array}$ & 16 anos \\
\hline $\begin{array}{c}\text { Morador } 11 \text { - grupo } \\
\text { jovens }\end{array}$ & 14 anos / Estudante & 8 anos \\
\hline
\end{tabular}

Tabela 9: Grupo focal de jovens (grupo focal de jovens realizado em 04 de Set. 2016)

Foram realizadas ainda observações de duas reuniões do Projeto Casulo, com registro e posterior análise dos apontamentos feitos pelos participantes, e visitas a campo para registros visuais e observações acerca da ocupação da área, comportamento dos moradores e estabelecimento de contatos.

Cabe ressaltar que a utilização de grupos focais aliada às entrevistas individuais realizadas no estudo facilitou a avaliação do confronto de opiniões, promovendo maior 
clareza do que as pessoas pensam sobre um tema específico, isoladamente e quando estão em debate em um grupo. Essas percepções também foram confrontadas com os dados gerados pela observação, permitindo comparar o conteúdo produzido no grupo com o cotidiano dos participantes em seu ambiente natural.

Parte relevante da pesquisa de campo envolveu também o registro de fotografias, utilizando-se a ideia da narrativa imagética para representar as condições nas quais a comunidade estudada está inserida e seus modos de vida. Para Silva (2006), ao contrário do que é usual para as ciências "humanas", a narrativa imagética não está estruturada no texto verbal, mas prioriza as imagens para representar a realidade estudada, evidenciar problemas e possíveis soluções. Ao considerar que a tecnologia pode potencializar um olhar crítico e inovador na educação, levando em consideração a estética produzida na cultura digital, a técnica de narrativa imagética instiga outros processos cognitivos de percepção e construção da imagem, orientando também a construção do conhecimento (ROSO; OLIVEIRA; MIRANDA, 2009). A imagem não é uma verdade em si, ela é uma interpretação que enfatiza algum aspecto sobre os demais, produzida por um sujeito (ROSO; OLIVEIRA; MIRANDA, 2009). Neste sentido, como argumentam Salvagni e Silveira (2013), desenvolver academicamente uma narrativa imagética, que contemple a tendência de uma cultura visual, parece acompanhar as transformações inegáveis da atualidade que utiliza os recursos visuais como algo intrínseco à realidade das relações. Os meios de comunicação, a propaganda e a internet ajudam a compor uma lógica de apresentação das relações humanas cuja imagem ocupa um lugar de excelência (SALVAGNI; SILVEIRA, 2013). Neste trabalho, e seguindo a ideia de Achutti (2004), a narração visual que se utiliza da fotografia é articulada ao texto escrito, buscando enriquecer e facilitar as interpretações dos dados, como reveladora das diferentes práticas culturais.

\subsection{O PROCESSO DA PESQUISA:}

Para o desenvolvimento da pesquisa, priorizou-se, primeiramente, a realização de reuniões com grupos pequenos de moradores. Na primeira reunião inicial, com três moradores, buscou-se explicar o que seria feito na pesquisa, quais seriam as formas de análise dos dados e conhecer um pouco do Real Parque, suas lideranças, possíveis 
contatos, propor as entrevistas e relatar a trajetória do pesquisador. Mais tarde, outra reunião foi realizada com dois moradores, buscando envolvê-los no desenvolvimento do questionário das entrevistas, levando em conta a percepeção dos residentes da área de estudo. Uma última reuinão, também com dois moradores, foi realizada com o objetivo de mapear possíveis participantes dos grupos focais. Foi nesta reunião também que foi discutida a proposta de observação das reuniões do Projeto Casulo, considerando a relevância deste projeto na comunidade e a presença de moradores nos encontros promovidos (nestas reuniões, participam em torno de 25 pessoas, que discutem a cada duas semanas problemas levantados que necessitam de estratégias de intervenção por parte dos residentes). Para além de observar os principais pontos debatidos pelos moradores nestas reuniões, identificar pontos de convergência e divergência, e compreender questões relevantes para a pesquisa realizada, estas reuniões ajudaram na identificação dos possíveis participantes dos grupos focais. As reuniões observadas do Projeto Casulo ocorreram nos dias 2 e 30 de Julho de 2016. As observações registradas também apontariam alguns dos aspectos a serem trabalhados na pesquisa, como questões administrativas do condomínio, questões ambientais como compostagem e reciclagem de resíduos (como opção econômica para alguns moradores), receios de surgimento de novos barracos na localidade (particularmente próximo ao mirante), questões de mobilidade (com discussões sobre transporte público e acesso de ônibus na comunidade) e problemas de educação (acesso a escolas).

A proposta inicial da pesquisa visava a realização de quatro grupos focais, envolvendo lideranças da comunidade, jovens, trabalhadores e pessoas do lar. Contudo, tendo em vista os problemas de adesão dos participantes convidados, optou-se pela realização de dois grupos focais, que foram realizados em julho e setembro de 2016. Esses encontros foram gravados, com consentimento dos participantes (que assinaram o Termo de Esclarecimento Livre e Esclarecido). O primeiro grupo focal foi misto, com a participação de 11 moradores dos condomínios, sendo mães de família, síndicos, lideranças da comunidade e residentes de diferentes idades. O segundo grupo focal foi realizado com 11 jovens e adolescentes, de idades variadas. Os dois grupos tiveram duração de pouco mais de duas horas.

Para esses encontros grupais, estabeleceu-se um roteiro de questões norteadoras: 
1) Questões iniciais - para identificar características comuns entre os participantes;

2) Questões introdutórias - para introduzir o tópico geral do debate e prover aos participantes uma oportunidade para refletirem sobre suas experiências passadas e conexões com os assuntos debatidos;

3) Questões de transição - para ajudar os participantes a vislumbrarem os temas tratados de um ângulo mais amplo;

4) Questões chave - para direcionar para o objeto de estudo;

5) Questões de finalização - para fechar a discussão, ajudando os participantes a refletirem sobre os comentários feitos.

Em geral, os grupos focais buscaram discutir com os participantes como é viver no Real Parque, quais são os pontos positivos e negativos da localidade; como foi o processo de reurbanização (como era antes do processo e como ficou hoje); quais as percepções sobre riscos e vulnerabilidades; os pontos positivos e negativos em relação à nova estrutura urbana e nova distribuição em condomínios; as atuais condições de vulnerabilidades enfrentadas; e possibilidades de ação - o que pode ser feito, como pode ser feito e como cada um pode contribuir para isso.

Os grupos focais foram uma estratégia relevante para esta pesquisa particularmente pela necessidade de compreender como os moradores sentiram as mudanças ao longo do processo de reurbanização. O uso dos grupos focais é uma técnica de investigação qualitativa comprometida com a abordagem metacientífica compreensivista, analisando os fatores que afetam o processo de discussão dos grupos focais e trazendo dados que ajudam na compreensão de uma realidade particular (GONDIM, 2003).

Morgan define grupos focais como uma técnica de pesquisa que coleta dados por meio das interações grupais ao se discutir um tópico especial sugerido pelo pesquisador. Como técnica, ocupa uma posição intermediária entre a observação participante e as entrevistas em profundidade (MORGAN, 1997). Pode ser caracterizada também como um recurso para compreender o processo de construção das percepções, atitudes e representações sociais de grupos humanos (VEIGA; GONDIM, 2001). 
O moderador de um grupo focal assume uma posição de facilitador do processo de discussão, e sua ênfase está nos processos psicossociais que emergem, ou seja, no jogo de interinfluências da formação de opiniões sobre um determinado tema. A unidade de análise do grupo focal é o próprio grupo. Se uma opinião é esboçada, mesmo não sendo compartilhada por todos, para efeito de análise e interpretação dos resultados, ela é referida como do grupo (GONDIM, 2003).

Para estabelecer os possíveis participantes dos grupos focais, bem como os moradores a serem entrevistados, foi fundamental o contato inicial com algumas lideranças da comunidade, previamente identificadas no âmbito do Projeto da Fapesp. $\mathrm{Na}$ reunião com essas lideranças, foi explicado o objetivo do estudo realizado, que também buscaria estabelecer uma maior aproximação e diálogo com os moradores (sujeitos da pesquisa). Posteriormente, uma das lideranças, síndica de um dos condomínios e engajada nas melhorias das condições da localidade, se prontificou a contatar outras lideranças, síndicos e moradores da área estudada para participarem do projeto. Mais tarde, ampliando o escopo dos participantes, visto a dificuldade em reunir lideranças e síndicos para os grupos focais, outros moradores foram contatados, incluindo jovens envolvidos em grupo de dança e projetos sociais da comunidade, estudantes e mães de família do Real Parque. A definição do roteiro de questões que norteariam os grupos focais e as entrevistas foi também resultado dessa colaboração com as lideranças, bem como dos contatos iniciais estabelecidos com residentes da comunidade.

O material coletado com os grupos focais, entrevistas e observações foi analisado a partir do que Duarte (2004) qualifica como análise temática, envolvendo unidades de significação ou categorias analíticas (DUARTE, 2004). As categorias de análise incluíram: $\mathrm{O}$ antes e o depois - mudanças nas condições de vulnerabilidade; Lugar, pertencimento e identidade; Demandas, necessidades para melhorar a qualidade de vida. Elas serão discutidas no próximo capítulo. Ressalta-se, contudo, as dificuldades encontradas em dividir e reorganizar o conjunto de dados nas categorias analíticas propostas, uma vez que há fortes conexões entre as categorias. Ainda assim, optou-se por considerar a especificidade dos temas tratados, sem impedir a exposição de interrelações temáticas do conjunto de dados. 


\section{CAPÍTULO 3: RESULTADOS DA PESQUISA}

Neste capítulo, são explorados os resultados da pesquisa, apresentados em três subcapítulos, a partir das categorias analíticas adotadas:

$\mathrm{O}$ antes e o depois - mudanças nas condições de vulnerabilidade - nesta categoria são apresentadas e discutidas as percepções dos moradores acerca do processo de reurbanização da área em que vivem e das condições de vulnerabilidade;

Lugar, pertencimento e identidade - nesta categoria são analisadas as falas dos moradores a partir da relação que estabelecem com o território habitado, incluindo as mudanças que surgiram a partir da reorganização do espaço e como elas impactam o cotidiano dos residentes;

Demandas e necessidades para melhorar a qualidade de vida dos moradores nesta categoria são apresentados e discutidos os apontamentos feitos pelos moradores acerca das necessidades da comunidade para uma melhoria na qualidade de vida.

Ao final de cada subcapítulo, e tendo como base a ideia da narrativa imagética, são disponibilizadas as fotos registradas durante a pesquisa de campo, que permitem uma articulação com o texto escrito, buscando enriquecer e facilitar as interpretações dos dados.

\subsection{O ANTES E O DEPOIS - MUDANÇAS NAS CONDIÇÕES DE VULNERABILIDADE}

Os dados coletados na pesquisa evidenciam que houve melhoras na qualidade de vida dos moradores, particularmente do ponto de vista dos riscos geológicos aos quais estavam expostos anteriormente. Contudo, o processo de reurbanização também levou a uma percepção modificada dos problemas e condições de vulnerabilidade enfrentados pela comunidade, particularmente quando motivados a pensar o "antes e depois", sobre como era a vida naquele território antes do processo e o que mudou posteriormente. Explorando a questão da vulnerabilidade, entendendo esta como condições (sociais, econômicas, demográficas, geográficas, etc.) que afetam a capacidade de responder a 
uma exposição, de enfrentar um possível perigo e risco (HOGAN, 2007), é possível observar no conjunto das falas dos moradores, tanto em entrevistas individuais quanto nos grupos, a emergência de novos problemas e conflitos, alguns evidenciados sobretudo pelo convívio em condomínios, e a maior visibilidade que passaram a ter algumas questões, para as quais sentem que sua capacidade de resposta ainda é baixa. Ao mesmo tempo que residir no novo projeto habitacional trouxe melhorias e bem-estar aos residentes, trouxe também novos problemas e potencializou outros que antes tinham menor visibilidade, não faziam parte do rol de preocupações cotidianas ou eram percebidos como menos relevantes. O quadro a seguir sintetiza os problemas e questões atuais enfrentados pelos moradores: 


\begin{tabular}{|c|}
\hline UESTÕES APON \\
\hline $\begin{array}{l}\text { 1- Necessidade de CNPJ dos prédios, para que os moradores pudessem ter a razão social } \\
\text { para eventuais pedidos frente à Prefeitura; }\end{array}$ \\
\hline $\begin{array}{l}\text { 2- Questões relacionadas ao desenvolvimento de um plano de reciclagem de resíduos na } \\
\text { comunidade, que ocuparia os moradores com um projeto ambiental, com benefícios } \\
\text { sociais e econômicos para os envolvidos; }\end{array}$ \\
\hline $\begin{array}{l}\text { 3- O receio da ocupação irregular da área do mirante, que ainda não é utilizada, e de } \\
\text { outros terrenos vagos na área levando à preocupação do aparecimento de novos } \\
\text { barracos; }\end{array}$ \\
\hline $\begin{array}{l}\text { 4- Questão sobre a entrada e circulação de ônibus na comunidade, levadas a SPTRANS, } \\
\text { já que problemas com a irregularidade das ruas, valetas e carros estacionados } \\
\text { impediriam a passagem desses veículos nas ruas da localidade. Os estacionamentos } \\
\text { irregulares, que dificultam a entrada e saída de outros veículos, também são citados; }\end{array}$ \\
\hline $\begin{array}{l}\text { 5- Individualização do relógio de água, uma vez que a água é dividida por cada } \\
\text { condomínio. }\end{array}$ \\
\hline 6- Necessidade de um espaço para atividades indor de jovens crianças; \\
\hline $\begin{array}{l}\text { 7- Destinação adequada para resíduos e compostagem de lixo, já que a comunidade } \\
\text { enfrenta problemas com despejos de resíduos nas vias e terrenos; }\end{array}$ \\
\hline $\begin{array}{l}\text { 8- Problemas com barulho em festas e a necessidade de locais adequados para a } \\
\text { realização das mesmas; }\end{array}$ \\
\hline 9- Comércios irregulares, como bares principalmente, que levam as pessoas ao ócio; \\
\hline 10- Necessidade de um posto de saúde na comunidade; \\
\hline $\begin{array}{l}\text { 11- Necessidade de melhorias nas condições da educação nas escolas próximas ao Real } \\
\text { Parque; }\end{array}$ \\
\hline $\begin{array}{l}\text { 12- Planos de inserção social das pessoas da comunidade, evitando deslocamentos dos } \\
\text { moradores para fora do Real Parque, em busca de opções de lazer, cultura e } \\
\text { entretenimento. }\end{array}$ \\
\hline
\end{tabular}

Se antes, por exemplo, havia preocupação por parte dos moradores quanto ao acesso à água e melhores condições de saneamento, hoje essa preocupação é deslocada para a necessidade de individualização dos relógios de água - uma vez que a água é 
dividida por cada condomínio. Certamente, isso é algo novo para os moradores que, muitas vezes, ou faziam ligações clandestinas para ter acesso à água ou contavam com uma estrutura precária, sem os benefícios de um sistema de abastecimento que possui valor de cobrança para que os indivíduos possam fazer uso de um bem fundamental para todos. A questão do acesso à água aparece em diversas falas dos moradores, tanto nas entrevistas individuais, quanto nos grupos focais e nas reuniões do Projeto Casulo, ao mesmo tempo como um problema econômico, já que os moradores em conjunto devem agora arcar com os valores pela distribuição do recurso, e como um problema ambiental, já que o desperdício no consumo parece ser prática recorrente e preocupante: "o uso com desperdícios eleva o custo da água para todos os moradores, mesmo sem necessariamente utilizar o benefício", relata um morador, queixando-se que passa o dia todo fora de casa, possui dois empregos e paga uma conta no final do mês que não condiz com o que utiliza. A compreensão de vida em grupo é uma dificuldade tanto para quem consome, quanto para quem paga pelo recurso.

Por outro lado, durante as entrevistas e os grupos focais, foi possível observar as mudanças positivas advindas com o processo de reurbanização, particularmente referentes aos riscos aos quais os moradores estavam expostos anteriormente relacionados ao tipo de moradia em que residiam. Durante o grupo focal misto, por exemplo, uma moradora menciona a questão dos incêndios, destacando um grande ocorrido em $2001^{14}$. A insegurança também estava relacionada às chuvas, em particular nos meses de maior quantidade de precipitação. Os moradores relatam que os riscos associados a solapamentos, deslizamentos de terra, invasão de água nas residências, doenças por conta de vetores, como leptospirose, dengue, entre outras, faziam parte do cotidiano da comunidade. As áreas mais íngremes do Real Parque também são associadas aos riscos aos quais os moradores estavam expostos no passado, particularmente para aqueles que residiam em áreas mais altas, sujeitas a problemas relacionados ao rompimento da estrutura de solo por conta da quantidade de água nos períodos mais chuvosos.

\footnotetext{
${ }^{14}$ Outro incêndio de grandes proporções foi registrado em 2010, nos alojamentos provisórios do empreendimento. Segundo Rezende (2015), este incêndio deixou cerca de 400 famílias desabrigadas, antecipando etapas do projeto de reurbanização em desenvolvimento.
} 
Na perspectiva de Veyret (2007), a vulnerabilidade também pode ser traduzida como a determinação dos danos máximos em função, por exemplo, de diversos usos do solo e dos tipos de construção. A vulnerabilidade coloca em jogo aspectos físicos, ambientais, técnicos, dados econômicos, psicológicos, sociais, políticos etc. Para a autora, a vulnerabilidade revela a "fragilidade de um sistema em seu conjunto e de sua capacidade para superar a crise provocada por um risco" (VEYRET, 2007). Para Bauman (2009), a noção de vulnerabilidade emerge com certo vigor no campo teórico de investigação dos fenômenos de espoliação social e econômica que ocorrem no espaço urbano contemporâneo, espaço este marcado por desequilíbrios de múltiplas ordens (BAUMAN, 2009). Kowarick (2009), nesta mesma direção, destaca a vulnerabilidade socioeconômica, referindo-se à situação de "desproteção a que vastas camadas pobres encontram-se submetidas no que concerne às garantias de trabalho, saúde, saneamento, educação e outros componentes que caracterizam os direitos sociais básicos de cidadania" (KOWARICK, 2009 - p. 86).

Se antes a condição de vulnerabilidade estava muito mais relacionada aos processos econômicos e espaciais de marginalização que, como destacam MENDES et al., 2011, constrangem certos grupos sociais a ocuparem áreas e zonas marcadas por perigos naturais, como os riscos de deslizamentos e solapamentos, agravados por uma ocupação desordenada e precária da localidade, hoje os moradores do Real Parque discutem questões do território associadas, por exemplo, ao acesso a transporte público e circulação de ônibus nas vias do condomínio, à inexistência de estacionamentos suficientes nos condomínios e a outros direitos sociais de cidadania, como acesso a bens e serviços.

Além disso, os moradores, como os grupos focais e reuniões evidenciaram, se queixam de que os condôminos dos prédios de alto padrão não permitem que sejam instalados pontos de ônibus na região. A inviabilização de um transporte público efetivo e de qualidade é apontado por eles como um ponto negativo em relação ao local onde vivem. A dificuldade de entrada de ambulâncias e carros de bombeiros, em casos de emergência e de possível incêndio, também é ressaltada. Neste ponto, alguns inclusive chamam a atenção para a questão da convivência em grupo, para o cumprimento de normas e regras de convivência: “A educação dentro do Real Parque é um ponto 
fundamental a ser discutido, pois se os próprios moradores colaborarem, muitos dos problemas serão resolvidos em casa mesmo", destaca um dos moradores. "Se a população residente tiver uma ação conjunta, visando o bem-estar geral, tenho certeza que poderemos avançar mais depressa rumo a melhores condições de vida”, menciona outro residente, durante um grupo focal.

É possível observar nas falas dos moradores durante os grupos focais e, particularmente nas reuniões do Projeto Casulo, que o território, que passou por um processo de reurbanização, é pensado também na perspectiva de ausências e ineficiências, como ausência de um posto de saúde ${ }^{15}$ mais próximo com horário de funcionamento 24 horas e de comércios na comunidade - hoje voltados praticamente a bares, o que colabora para o barulho e para o ócio, mas também facilitaria a ocorrência de problemas com álcool e outras drogas. Para além das queixas comuns em relação à necessidade de grandes deslocamentos em direção ao trabalho ou para a escola, com gastos tanto de tempo como de dinheiro (com vans para transporte das crianças), a questão da segurança pública também é citada como um problema geral enfrentado pela comunidade.

De maneira mais ampla, vulnerabilidade, como discutem Wisner et al. (2004), é um processo constituído por componentes que envolvem causas profundas - fatores históricos, políticos, econômicos, ambientais e demográficos que levam às desigualdades. Os autores apontam também as pressões dinâmicas, como processos

\footnotetext{
${ }^{15}$ A UBS Real Parque - Dr. Paulo Mangabeira Albernaz Filho, que atende o Real Parque, está localizada na Avenida Barão de Melgaço, 339, com atendimento de segunda à sextafeira, das 7 às 19 horas, com fechamento aos finais de semana. Na UBS, é possível receber atendimentos básicos e gratuitos em Pediatria, Ginecologia, Clínica Geral, Enfermagem e Odontologia. Os principais serviços oferecidos são consultas médicas, inalações, injeções, curativos, vacinas, coleta de exames laboratoriais, tratamento odontológico, encaminhamentos para especialidades e fornecimento de medicação básica (Disponível em: http://www.pac.gov.br/infraestrutura-social-e-urbana/ubs-unidade-basica-de-saude. Acesso em: 15 de Mai. 2017). Contudo, nas suas queixas, os moradores pedem uma UBS integral, que funcionasse 24 horas por dia, no modelo de uma ESF (Estratégia de Saúde da Família), atendendo a demanda por consultas ambulatoriais de casos agudos de média complexidade, garantindo pronto atendimento clínico e pediátrico, além de procedimentos de enfermagem e raio-x à populaçãotodos os dias da semana. Neste sentido, relatam que quando há necessidade de se deslocarem para uma unidade que atenda problemas mais complexos, ou com atendimento 24 horas, precisam se dirigir a UPA - Vila Santa Catarina, que não atende aos domingos e funciona apenas em horário comercial e fica a uma distância de $9,2 \mathrm{~km} \mathrm{da}$
} 
sociais específicos como, por exemplo, uma rápida urbanização e condições de vida pouco seguras, que levariam à exposição desigual a um risco. Neste sentido, vulnerabilidade depende também da capacidade de resistência e de resiliência dos indivíduos e das comunidades mais afetadas (WISNER et al., 2004).

$\mathrm{Na}$ área do Real Parque, é possível observar uma divisão estabelecida entre os prédios mais antigos (Cingapura) e os prédios novos, que fazem parte desse atual processo de reestruturação urbana. Ao compararem as duas intervenções habitacionais, os moradores participantes do grupo focal misto evidenciam algumas diferenças que se reverberam no cotidiano local, apontando, por exemplo, problemas crônicos que existiriam no Cingapura, como lixo nas ruas e excesso de barulho dos carros com som muito alto, e lembram que esta parte da comunidade é a "mais arriscada" do ponto de vista da segurança, tanto para pessoas de dentro do Real Parque como para visitantes. Problemas com drogas e criminalidade são destacados pelos entrevistados como "piores" nas imediações do Cingapura.

Se os problemas parecem mais sérios e graves "do lado de lá", também faz-se notar, pelas falas dos moradores, tanto nas entrevistas individuais como nos grupos focais, a preocupação constante de que novas ocupações irregulares se estabeleçam nos terrenos nas imediações hoje ainda não utilizados, comprometendo o "bom funcionamento da comunidade". Para os moradores, estes novos residentes que viriam não teriam a infraestrutura urbana que agora goza o Real Parque, acarretando problemas, como distribuição de água e luz, ou mesmo de criminalidade. É possível enxergar, assim, uma hierarquização que surge na comunidade, assim como existe dentro do próprio bairro com relação à comunidade, trazendo esferas e divisões entre os próprios moradores: os que moram no Cingapura, os que moram na nova área revitalizada do Real Parque, e os que poderiam vir a ocupar os terrenos vazios.

Vulnerabilidade, como argumentam Marandola Jr e Hogan (2009), tornou-se uma expressão idiomática retórica, servindo para expressar a retórica da perda. Para os autores, em todos os campos que se detecta a perda (de bens, de cidadania, de saúde, de qualidade de vida, de renda, de vidas etc) lança-se mão da vulnerabilidade para

localidade, a UPA - Jardim Conceição, em Osasco, que fica a 14,6 km, ou a outras opções mais distantes. 
expressar o que foi perdido, com um conteúdo retórico forte, mas com diferentes densidades conceituais. Discutir vulnerabilidade requer compreender as diferentes dimensões envolvidas (relacional, circunstancial e espacial), mas também entender “vulnerabilidade a que?", como argumentam os autores (MARANDOLA JR; HOGAN, 2009).

Para o geógrafo Ribeiro (2010), a vulnerabilidade é social, antes de tudo. Ela é definida pela posição do grupo social na sociedade e de cada indivíduo no interior do grupo. A associação com a renda é direta. Invariavelmente são as camadas mais pobres da população a sofrerem mais com as situações de risco, quaisquer que sejam elas (RIBEIRO, 2010). Desde esta perspectiva, por exemplo, uma das moradoras, durante o grupo focal misto, evidencia na sua fala sua sensação de "regressão" do ponto de vista de sua moradia. Se antes vivia em um sobrado, com ótima localização, em uma rua principal na área da antiga favela, hoje, ainda que o entorno tenha melhorado muito, seu apartamento é muito menor que sua antiga casa, que não era um barraco. Além disso, ela menciona problemas com vizinhos que fazem barulho, reclama da localização da nova casa, que não é boa, e do fato de estar em um condomínio que não tem vista para a rua, como antigamente tinha em seu sobrado. Para ela em específico, a situação piorou, individualmente. Entende que, como um todo, a infraestrutura teve uma melhora completa, porém surgiram problemas que ela não enfrentava anteriormente. Como ainda existem alguns remanescentes de barracos na área, a moradora também levanta a questão de que alguns não pagam nada e vivem no mesmo lugar, fazendo uso, pelo menos de uma parte, da infraestrutura que agora é paga por todos, como luz e água.

As falas dos moradores, nas entrevistas individuais e grupos focais, podem ser pensadas à luz do entendimento de que vulnerabilidade é aquilo que marca os destituídos de garantias sociais, fragilizados pela carência de recursos de várias ordens para se protegerem nos embates do dia a dia (KOWARICK, 2009). Desde este entendimento, pode-se compreender que os recursos escassos da comunidade do Real Parque tornam os moradores vulneráveis do ponto de vista social, com dificuldades de usufruir dos benefícios oferecidos aos residentes de uma grande cidade, como é o caso da cidade de São Paulo, mesmo após o processo de revitalização urbana pelo qual a região passou. Neste sentido, a experiência do Real Parque pode também ser pensada 
desde a perspectiva de segregação social versus processo de integração. Nos últimos anos, a ideia de mistura social (mix social) vem chamando atenção mundialmente, associada particularmente a fortes discursos políticos contra a exclusão social, no combate à pobreza e na promoção de uma agenda pró-gentrificação (LEES; BUTLER; BRIDGE, 2012). Numa perspectiva histórica, Sarkissian (1976) destaca a idéia de "mistura social" que se originou no estilo das experiências inglesas que procuraram reverter o espaço de segregação produzido pela urbanização capitalista e restaurar certos elementos das comunidades pré-industriais, baseada numa ordem moral partilhada. Desenvolver espaços urbanos, tais como grandes parques urbanos, com base em códigos de conduta comuns, independentemente das classes que os utilizariam, criando um conceito de "unidade social através da diversidade", levaria a uma visão mais igualitária e racional para a mistura social entre as classes, concedendo às pessoas de origens mais humildes o acesso a uma habitação decente e de boa qualidade (ROSE et al., 2013).

A ideia de um processo de integração de classes sociais tem ganhado concretude, por exemplo, em cidades canadenses, como Toronto, que vivenciam uma miscigenação social de bairros de renda mista, nos quais as populações vivem de forma integrada, respeitando suas diferenças e limitações ${ }^{16}$ (LOBO, 2011). A experiência da localidade conhecida como Regent Park é um exemplo desse movimento. O mais antigo projeto de habitação social na América do Norte, construído na década de 1940 como um experimento social no lado leste de Toronto, para as populações mais pobres e para os que regressaram da Segunda Guerra Mundial, tornou-se anos mais tarde atraente para imigrantes e para uma classe trabalhadora por causa da disponibilidade de habitação subsidiada acessível (KOMAKECH; JACKSON, 2016) ${ }^{17}$, misturando atualmente

${ }^{16}$ O Regent Park está sendo reconstruído como uma comunidade mista de moradores com níveis de renda diversos num bairro aberto e integrado. Cinqüenta anos antes, Regent Park fora desenhado como uma comunidade de baixa-renda, composta inteiramente de habitação social mas cercada por barreiras que minavam o acesso ao emprego, à boa educação e às oportunidades para os seus residentes, como tantos outros conjuntos habitacionais no resto do mundo. Sua atual renovação está abrindo-o, adicionando novas ruas e parques para reconectá-lo à vizinhança e para receber novos residentes com uma gama maior de níveis de renda, profissões, qualificações, relacionamentos e origens étnicas. Disponível em: http://www.toronto.ca/legdocs/mmis/2007/ex/bgrd/backgroundfile-7300.pdf. Acesso em: 10 de mai. 2017.

${ }^{17}$ Em 2005, a renovação urbana começou derrubando os edifícios antigos e deslocando os moradores por até quatro anos para construção de novas estruturas em uma configuração diferente do que era antes. Esta renovação substituiu as 2083 unidades de aluguel e construiu 
diferentes níveis de renda e possibilitando acabar com o isolamento das classes mais pobres. Esse conceito de habitação de renda mista tem origem na Teoria do isolamento social, a qual destaca que os moradores de bairros de alta pobreza são isolados de redes e oportunidades de trabalho informais, sendo necessário sua inclusão para evitar este isolamento (KOMAKECH; JACKSON, 2016).

Como argumenta Lobo (2011), em seu artigo sobre a experiência do Regent Park, pesquisas têm demonstrado que comunidades de renda-mista podem ter um impacto positivo nas oportunidades e desempenhos para residentes de todas as origens sociais. No caso específico dessa experiência canadense, foi criado um plano de desenvolvimento social que compreende uma força tarefa de emprego, envolvendo sustentadores locais e vizinhos, bem como órgãos públicos. Para promover a mudança social da localidade foram produzidos um mapa relacional e um plano de investimento social, para o qual foi criado um fundo. As escolas desempenharam papel fundamental no desafio de superar os obstáculos à inclusão social, podendo permanecer abertas após o horário de aulas a fim de promover atividades que envolvam alunos, pais e a comunidade mais ampla (LOBO, 2011). Foi envolvido também um plano de miscigenação social, que privilegia na cidade considerada a mais multicultural do mundo (Toronto) uma diversidade de estilos de vida valorizada e cultivada por muitos canadenses (QADEER, 2004), misturando etnias e rendas.

No caso do Real Parque, embora o projeto de reurbanização possibilite sensíveis melhoras em termos de moradia, a análise das falas dos moradores evidencia que a perspectiva de segregação social ainda persiste, e um processo de integração de fato da comunidade com as famílias que habitam o entorno ainda está longe de ser uma realidade.

As fotos a seguir, numeradas de 5 a 28 , representam os problemas e condições de vulnerabilidade evidenciados pelos moradores e discutidos neste subcapítulo, incluindo terrenos não ocupados que poderiam dar lugar a uma Unidade Básica de Saúde - UBS integral (fotos de 5 a 7; 17 e 18), ou mesmo para outras finalidades, como locais para as atividades culturais e educacionais dos moradores; s ruas estreitas, que 
dificultam a circulação de veículos pelo interior da comunidade, bem como carros abandonados e lixo acumulado nas calçadas (fotos de 8 a 11); ponto de ônibus em localidade considerada de risco alto de assaltos, pelo isolamento com os prédios de alto padrão e muros extensos (foto 12); excesso de carros de som e bares na localidade (fotos 13 a 16); o receio de novas ocupações e problemas de convivência (fotos 19 a 23); e a necessidade de mais infraestrutura para a comunidade (fotos 25 a 28).
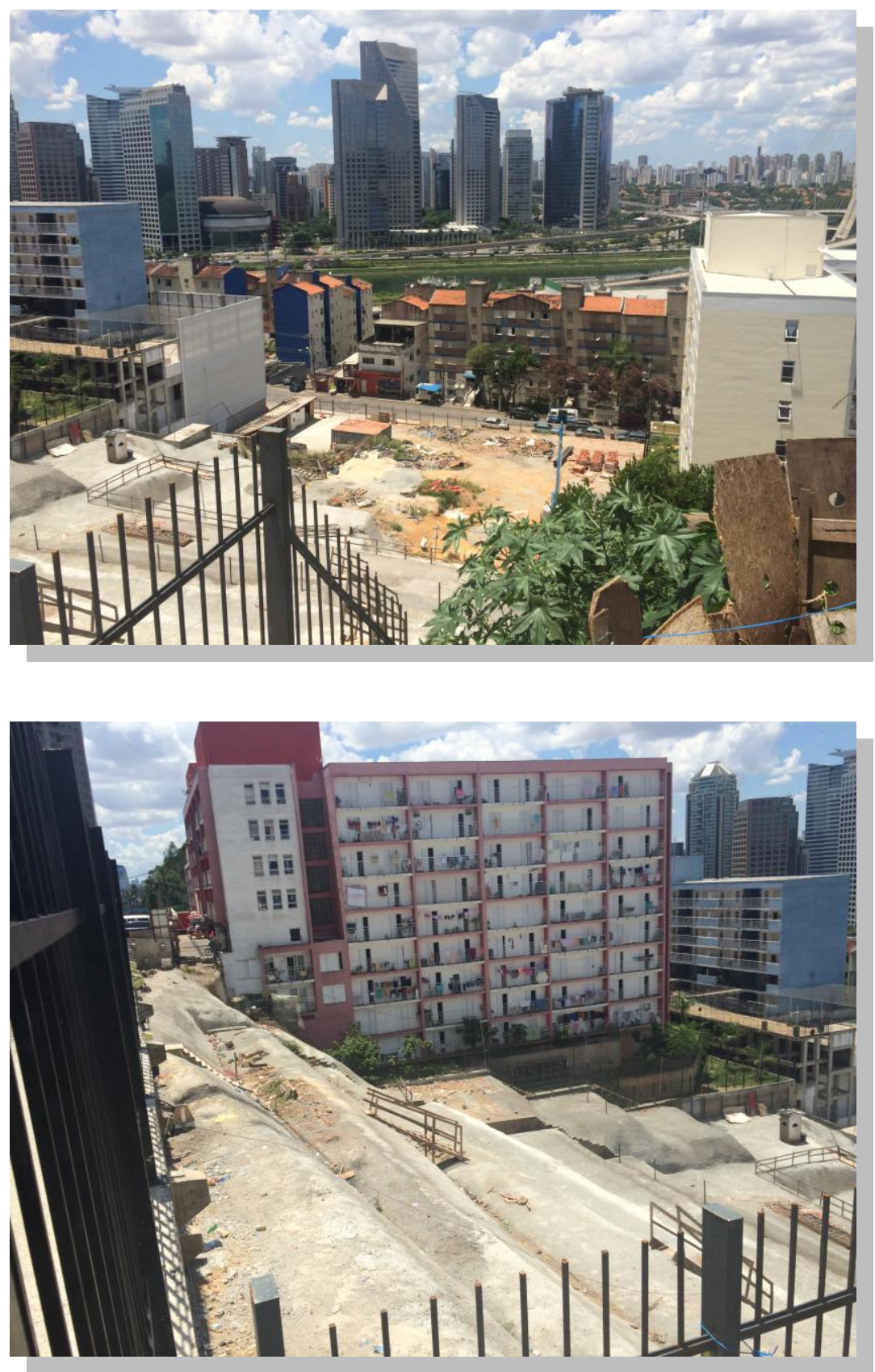

Fotos 5 e 6: Área onde os moradores reividicam a construção de uma UBS (Unidade Básica de Saúde) integral ou um posto de saúde

Fotos: Tiago Prado 


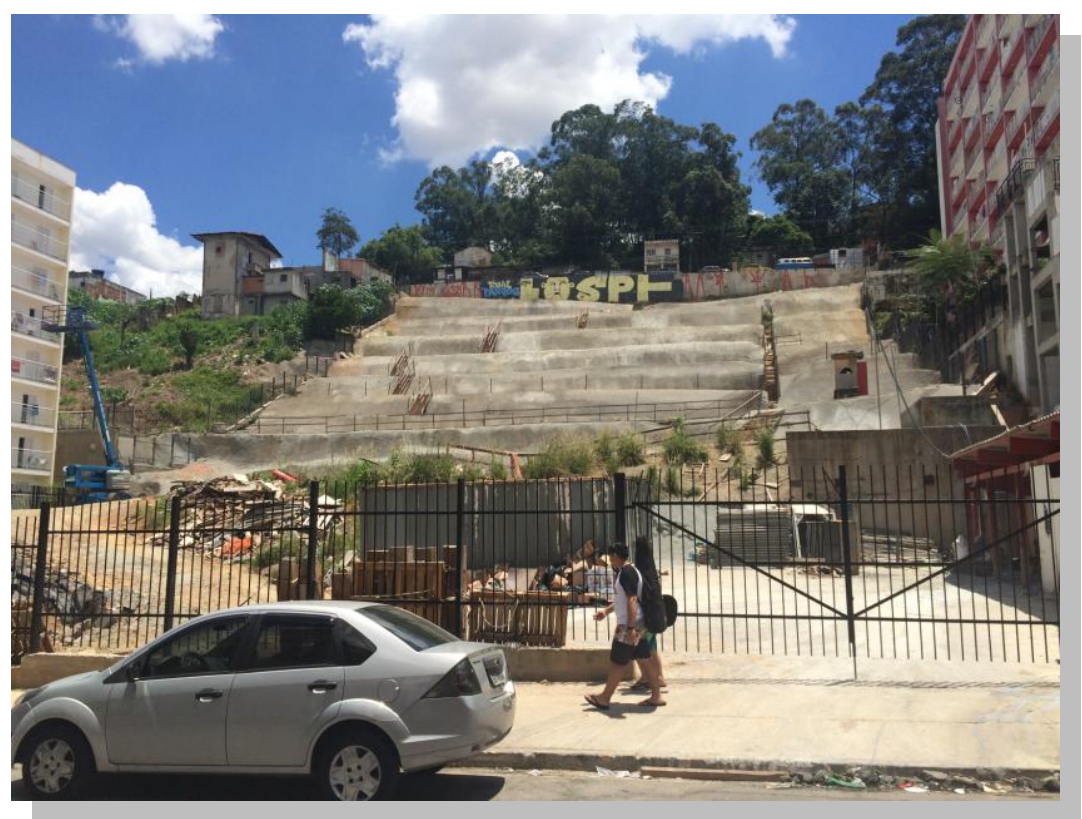

Foto 7: Mesma área reivindicada, vista de baixo

\section{Foto: Tiago Prado}

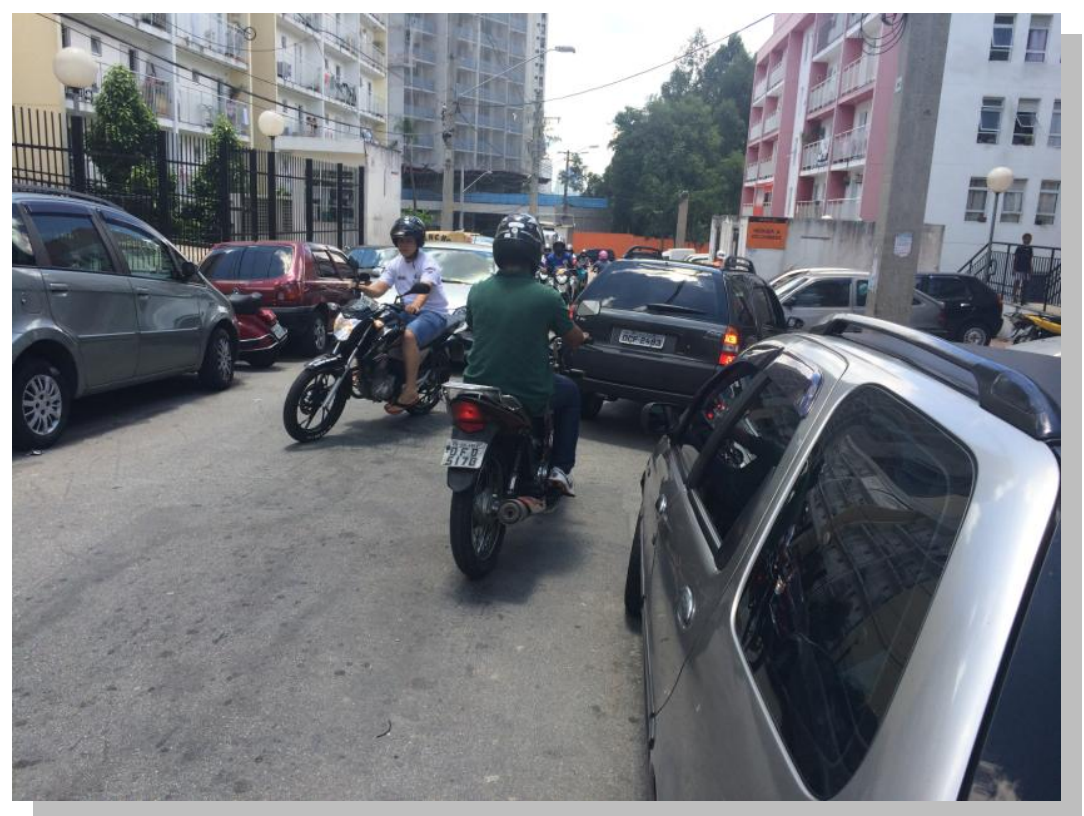

Foto 8: Rua com veículos parados em locais irregulares dificultando a passagem de veículos

\section{Foto: Tiago Prado}




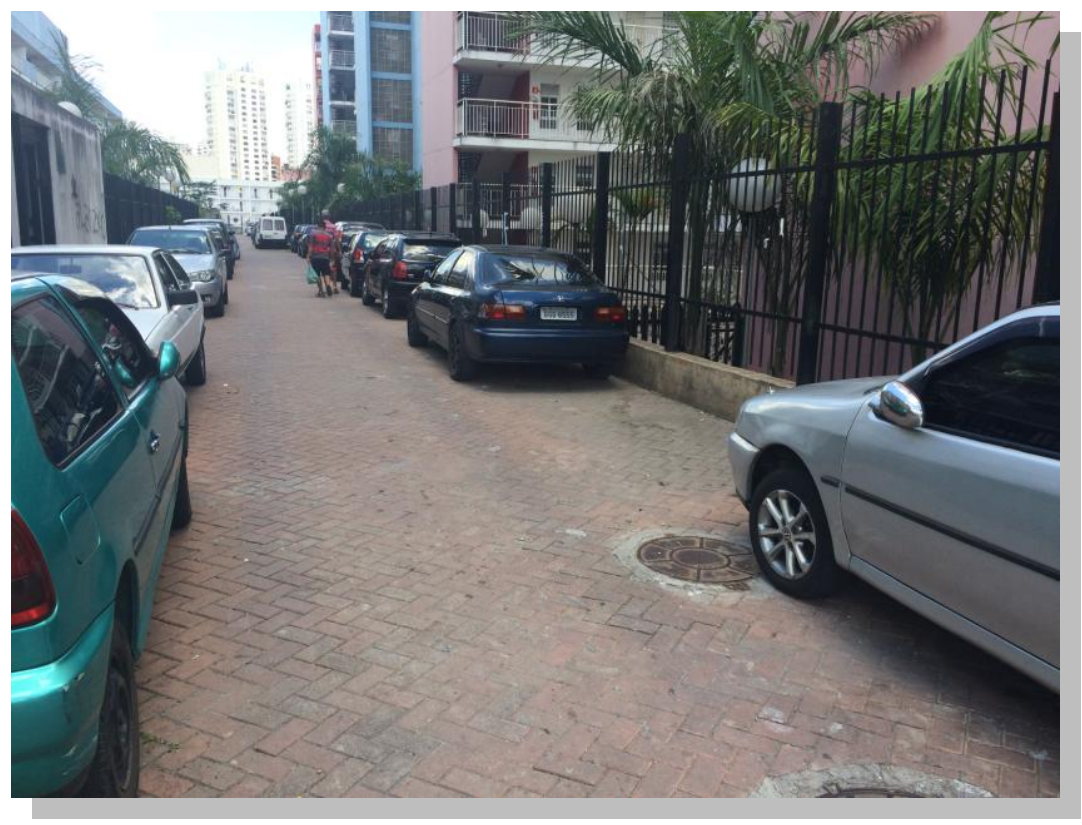

Foto 9: Ruas muito estreitas com veículos estacionados dos dois lados

\section{Foto: Tiago Prado}

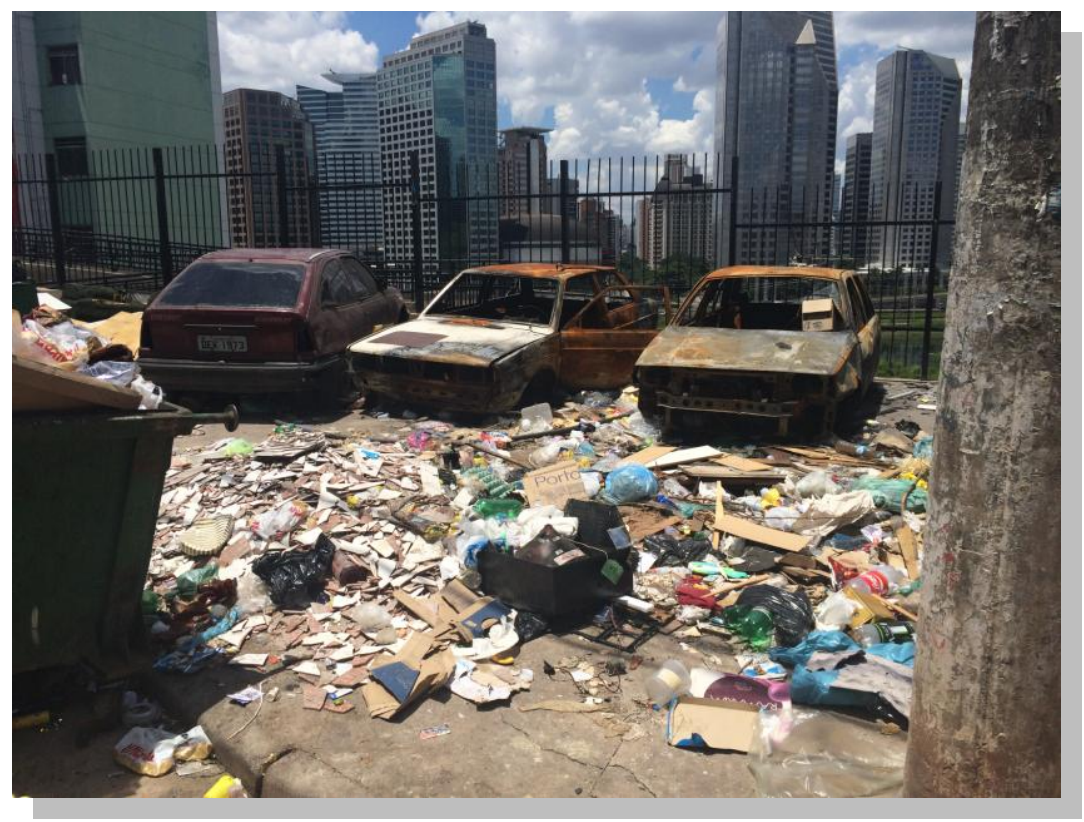




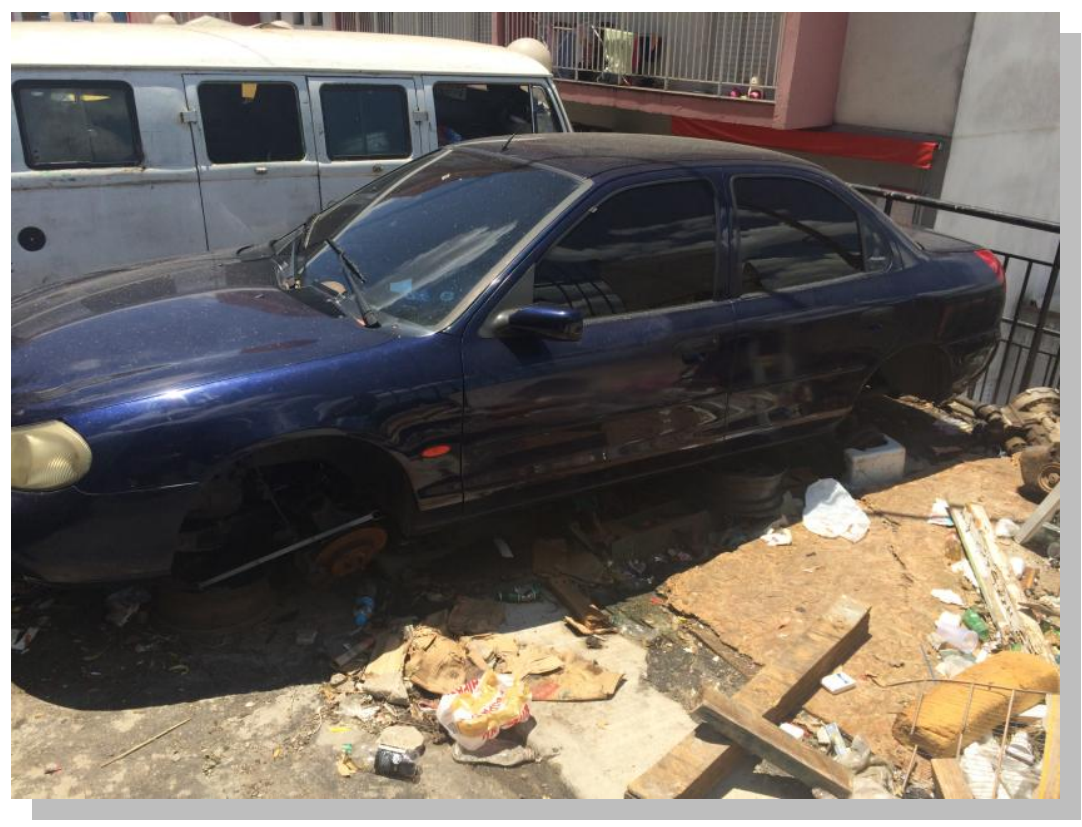

Foto 10 e 11: Veículos abandonados pelas ruas e lixo nas calçadas

\section{Fotos: Tiago Prado}

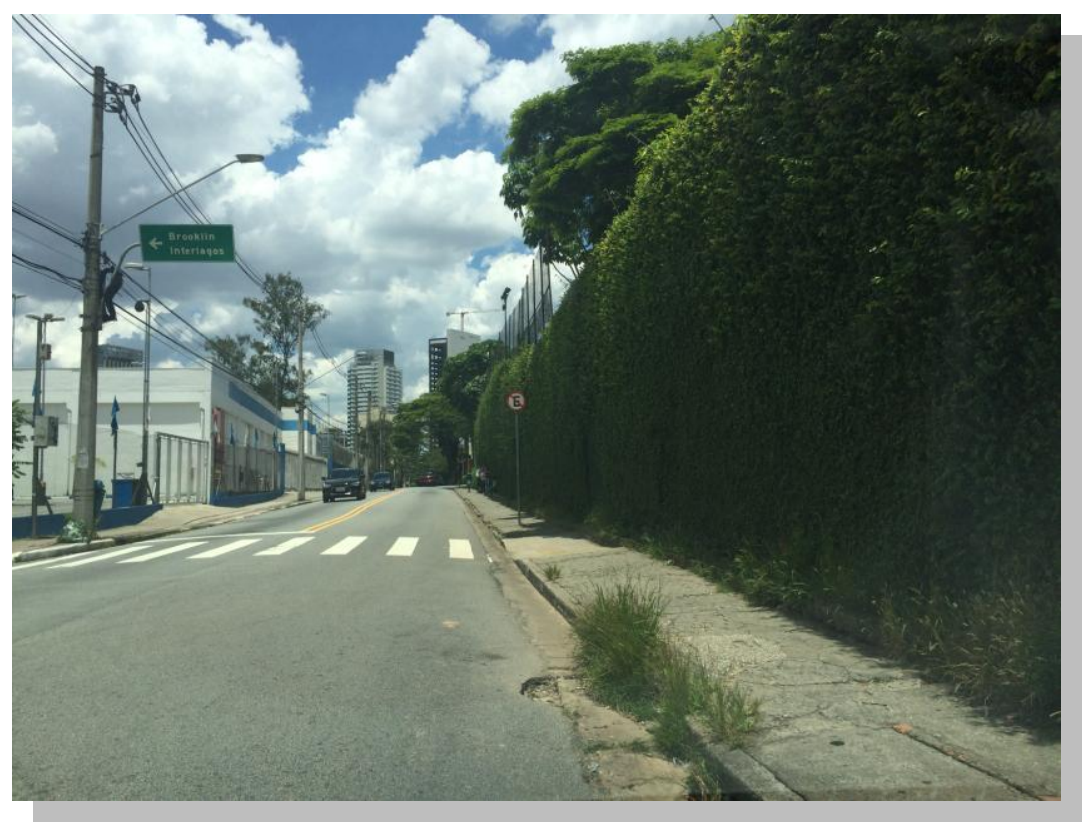

Foto 12: Ponto de ônibus (ao fundo) - falta de segurança pelo isolamento por muros e distância do conjunto habitacional

\section{Foto: Tiago Prado}




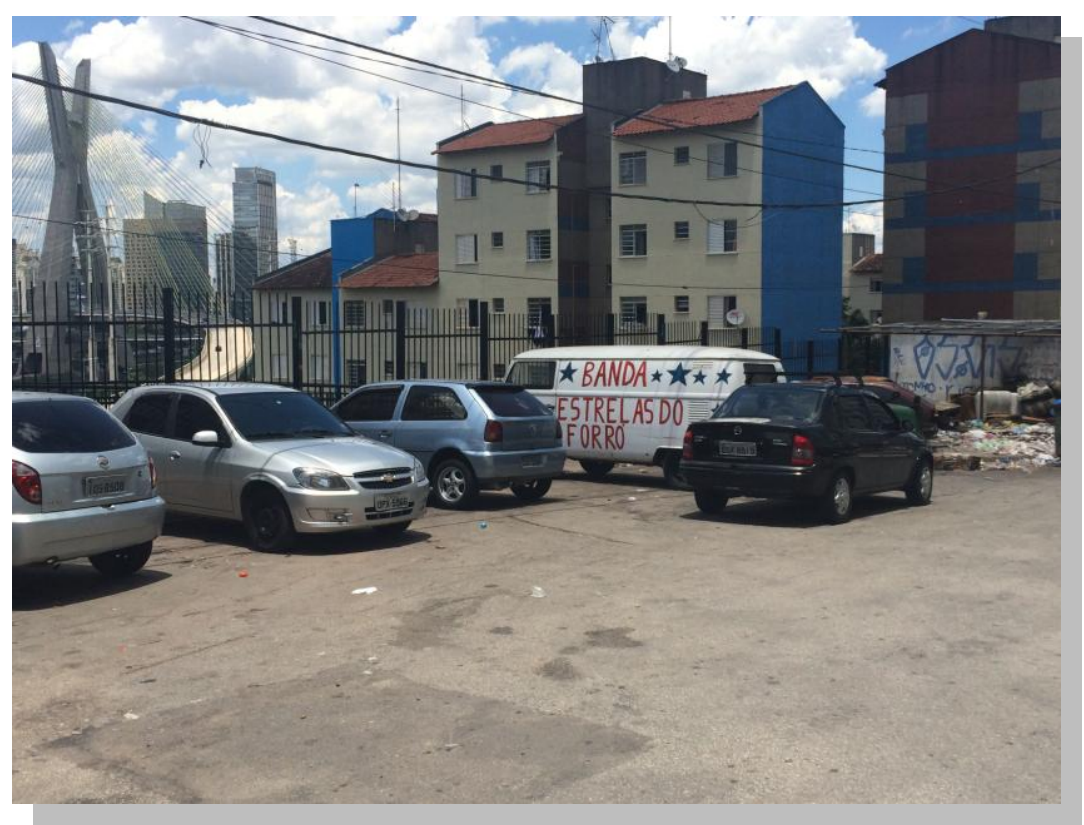

Foto 13: Carro de som utilizado em festas, um dos problemas destacados pelos moradores, na rua entre os novos condomínios e o Cingapura

\section{Foto: Tiago Prado}

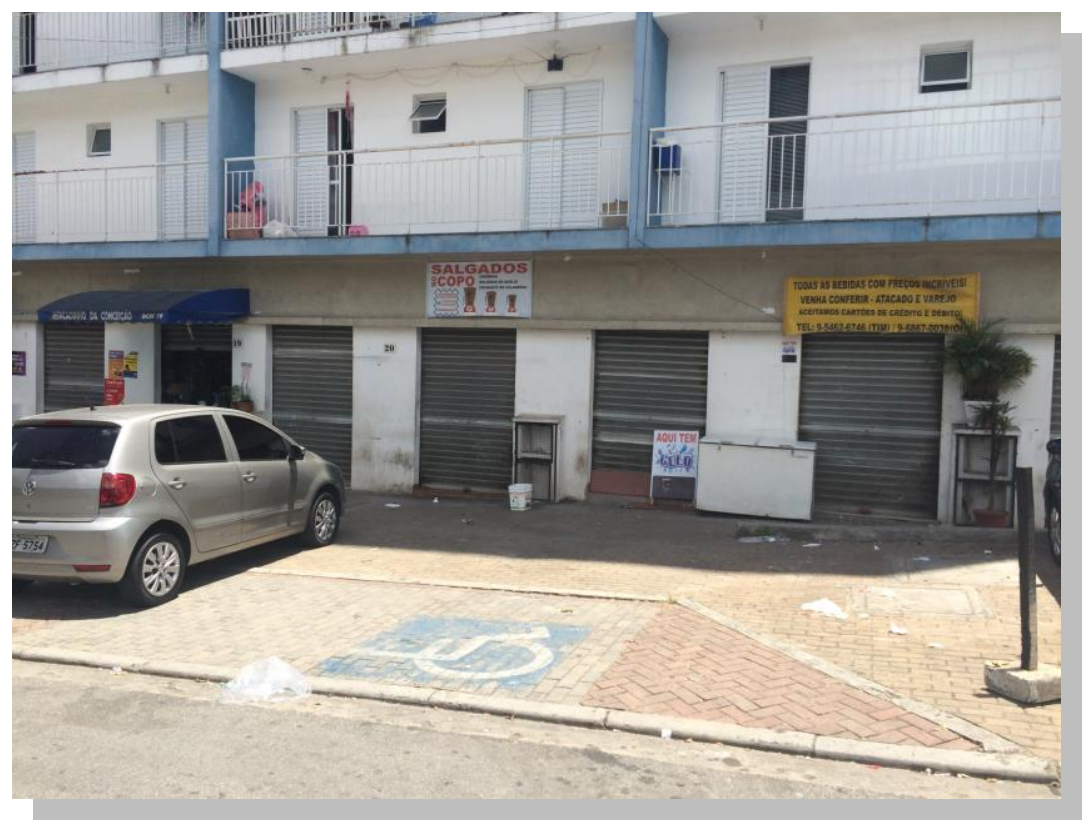

Foto 14: Comércio na parte térrea dos condomínios - existência de muitos bares

\section{Foto: Tiago Prado}




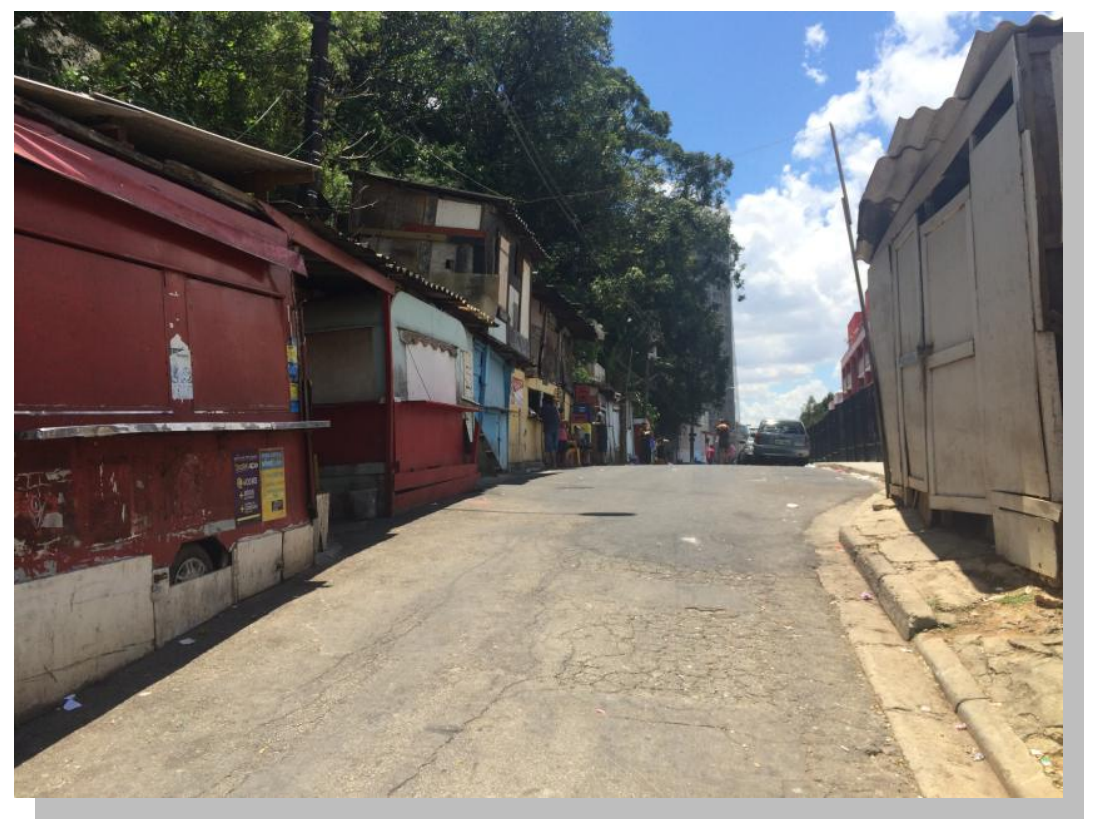

Foto 15: Comércios irregulares

\section{Foto: Tiago Prado}

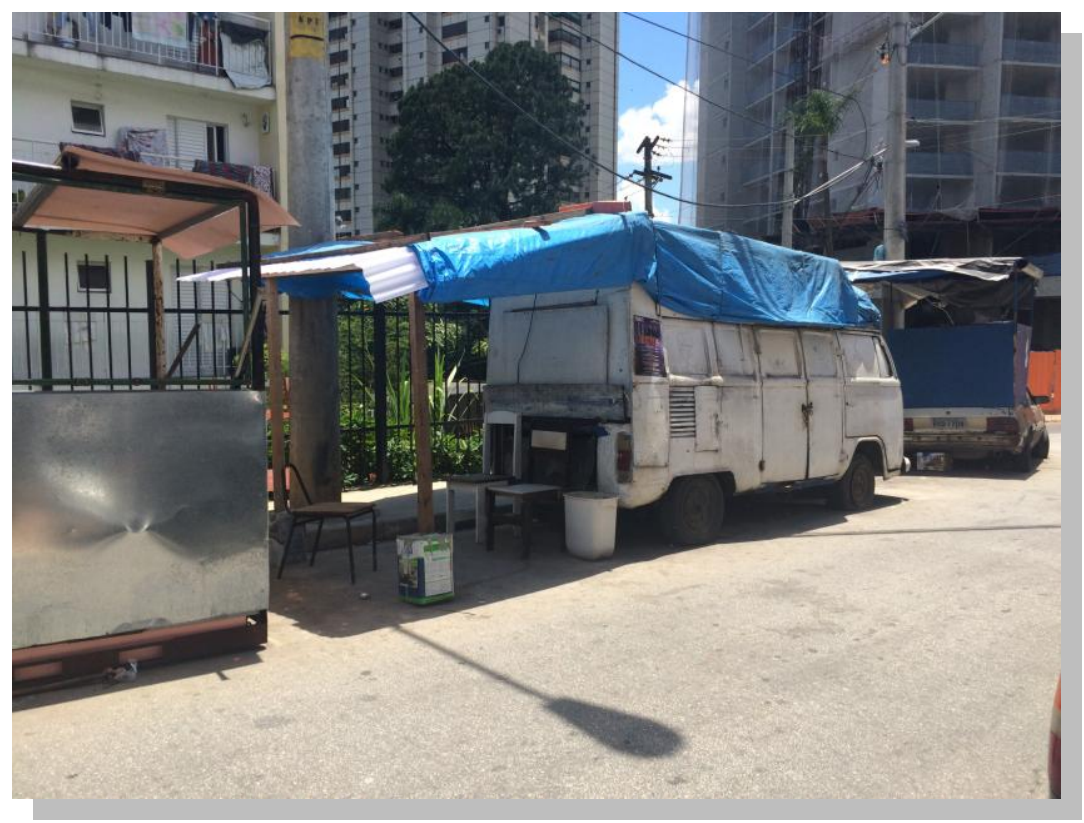

Foto 16: Carros de comércios irregulares em frente aos condomínios

\section{Foto: Tiago Prado}



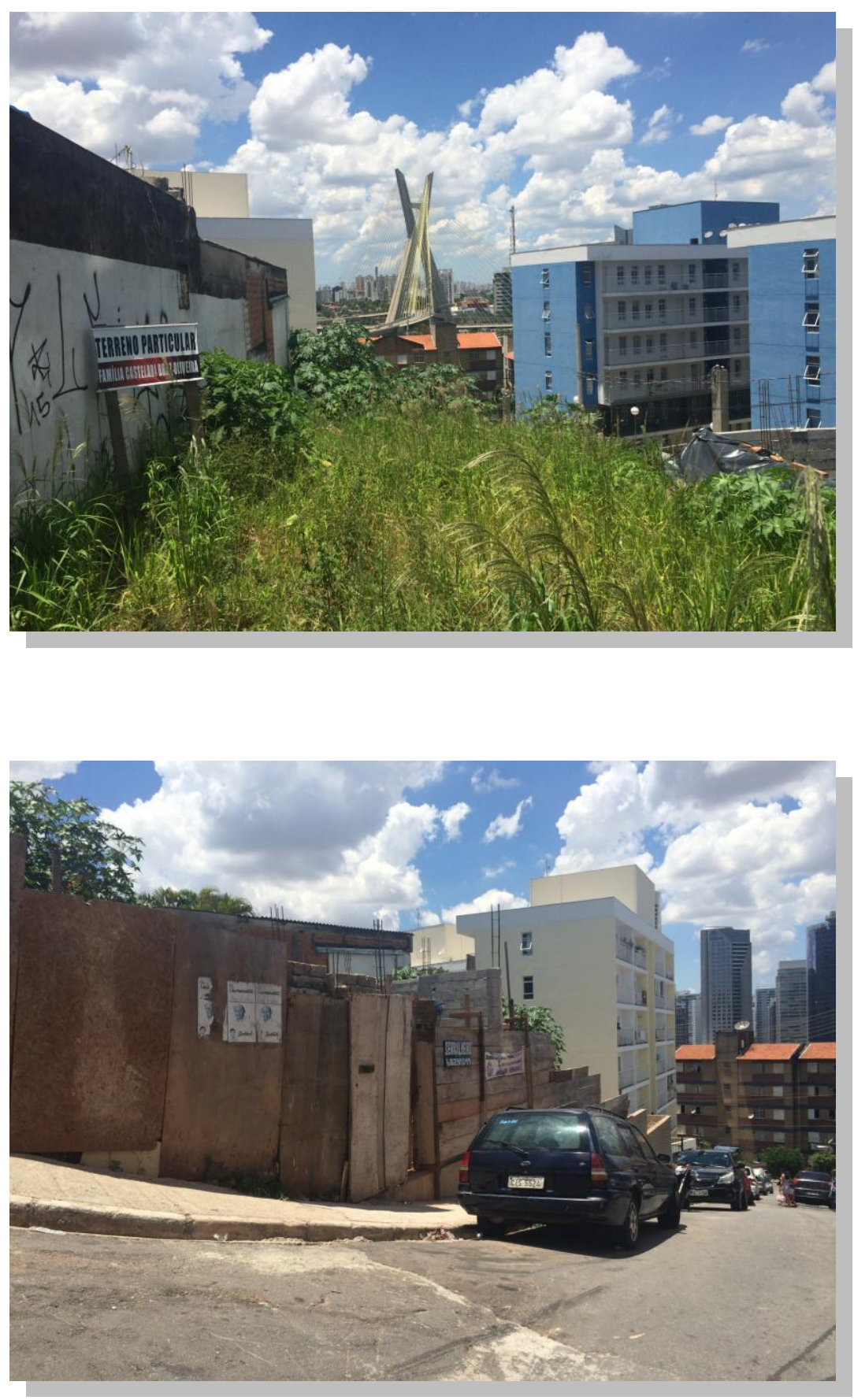

Foto 17 e 18: Terrenos desocupados que poderiam ser usados para construção de infraestrutura para a comunidade e que são potenciais locais para o surgimento de novos barracos

\section{Fotos: Tiago Prado}



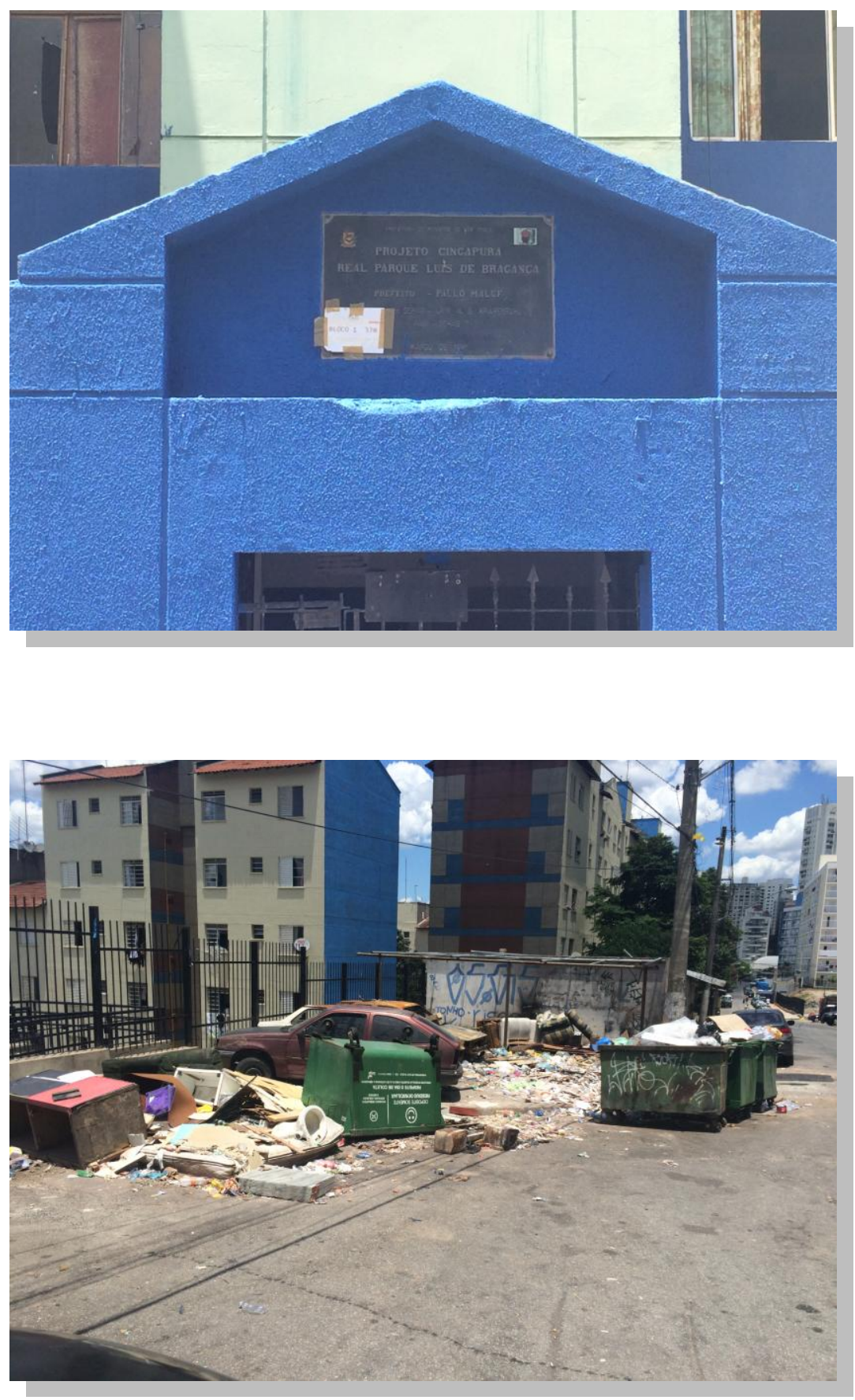


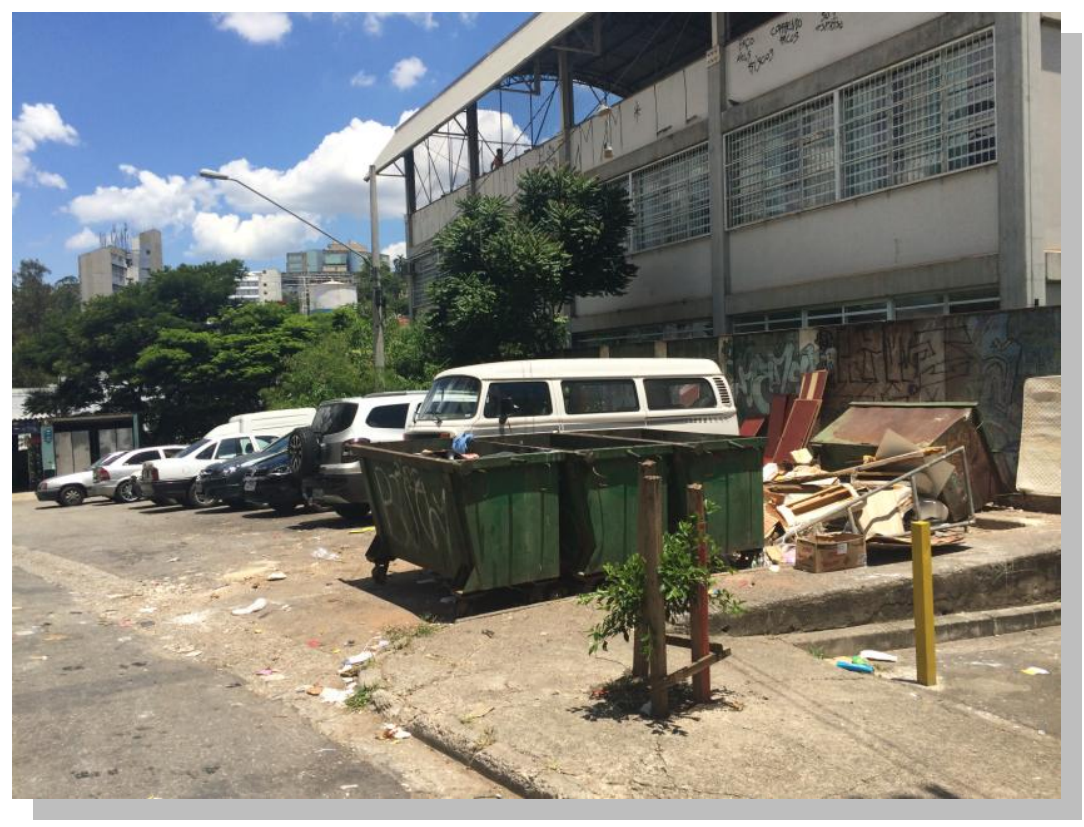

Foto 19, 20 e 21: Prédios do Cingapura e as diferenças apontadas pelos moradores, incluindo o excesso de lixo descartado nas ruas

\section{Fotos: Tiago Prado}

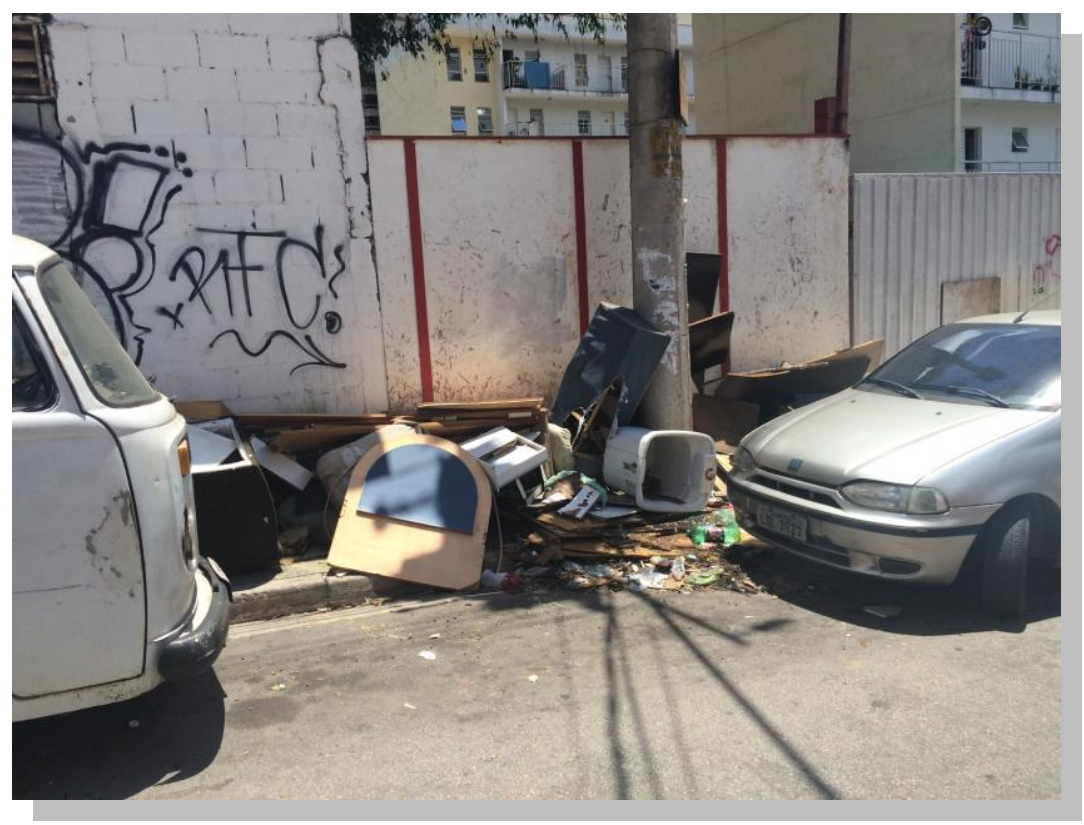

Foto 22: Entulho nas calçadas

\section{Foto: Tiago Prado}




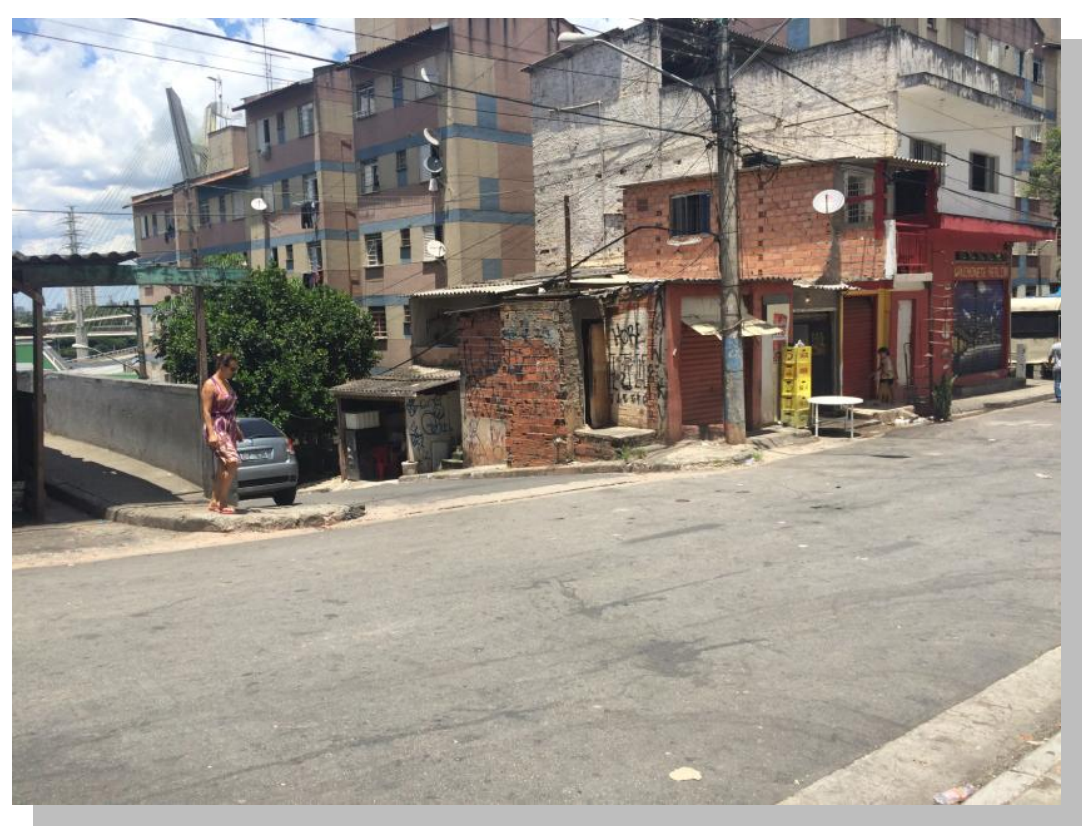

Foto 23: Ocupações irregulares

\section{Foto: Tiago Prado}

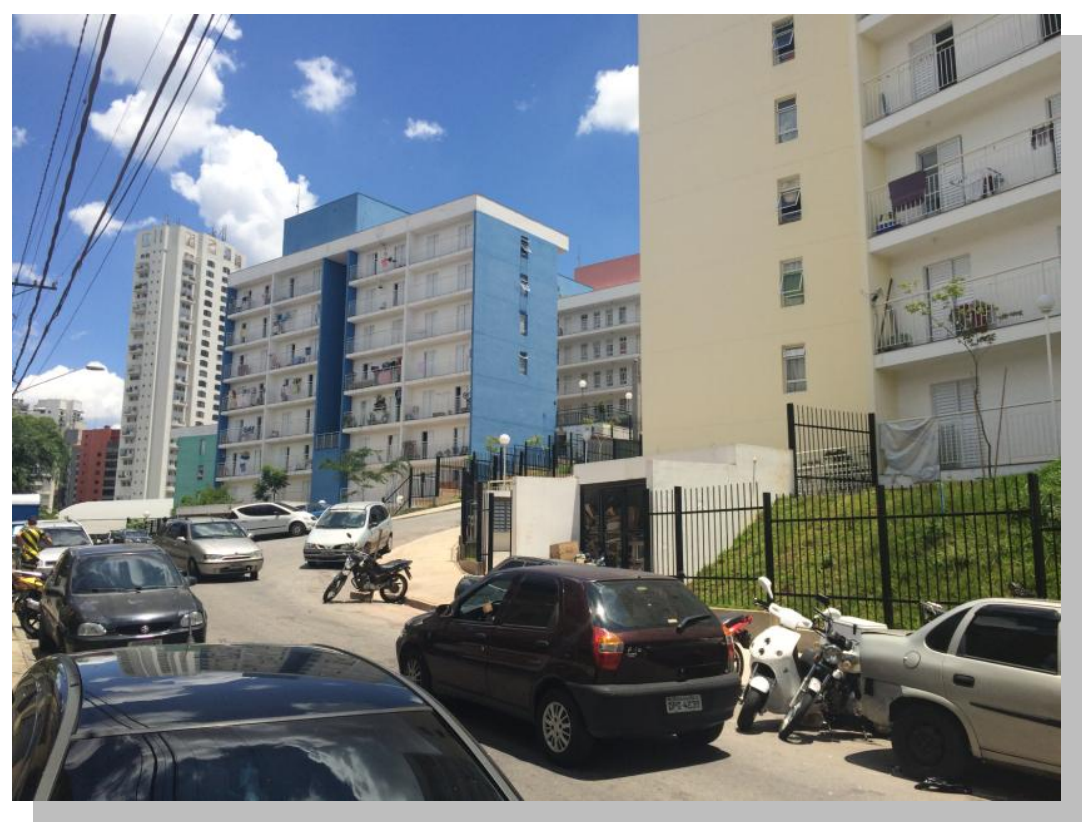

Foto 24: Vista de frente para a foto 23 (comparativo)

Foto: Tiago Prado 

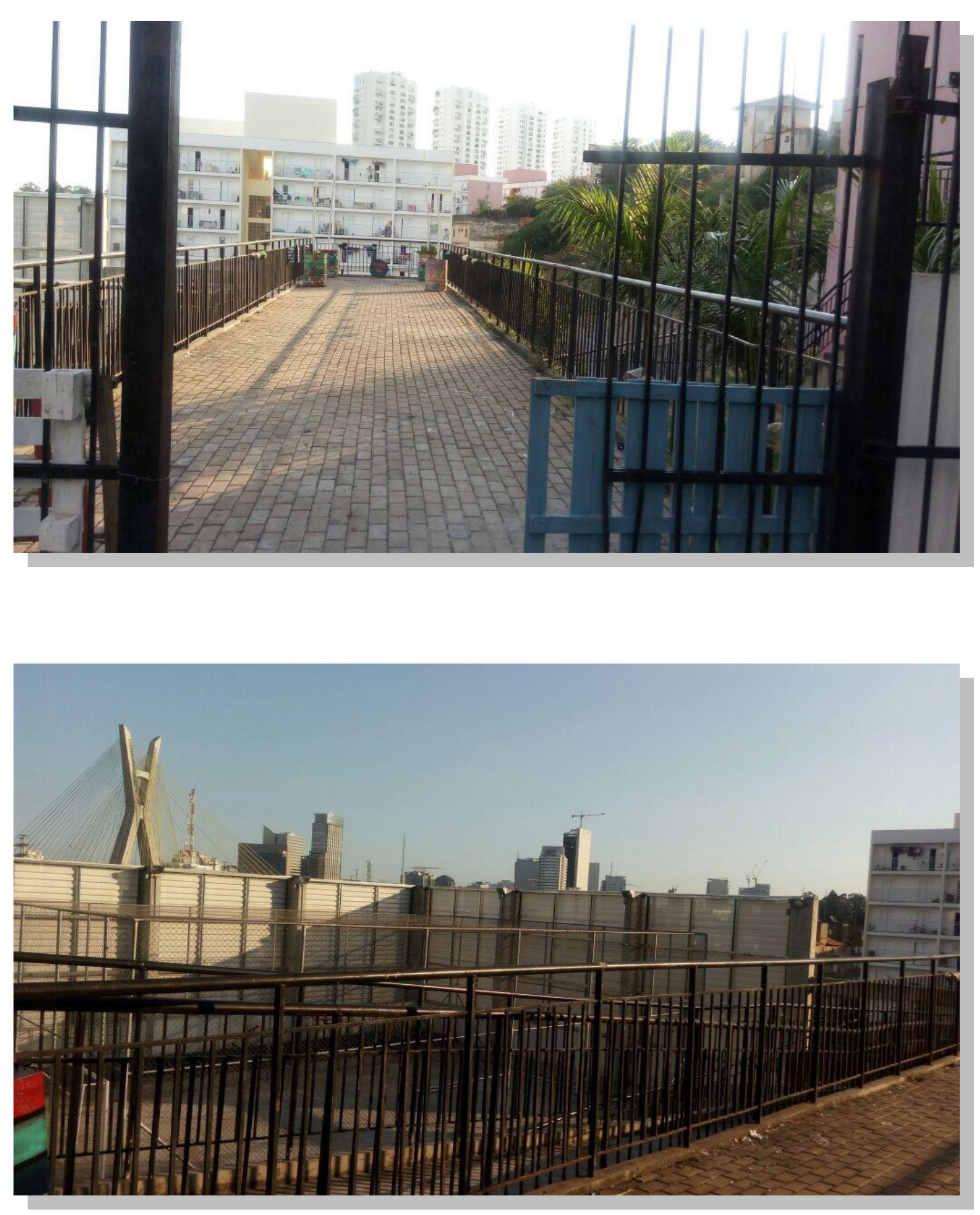

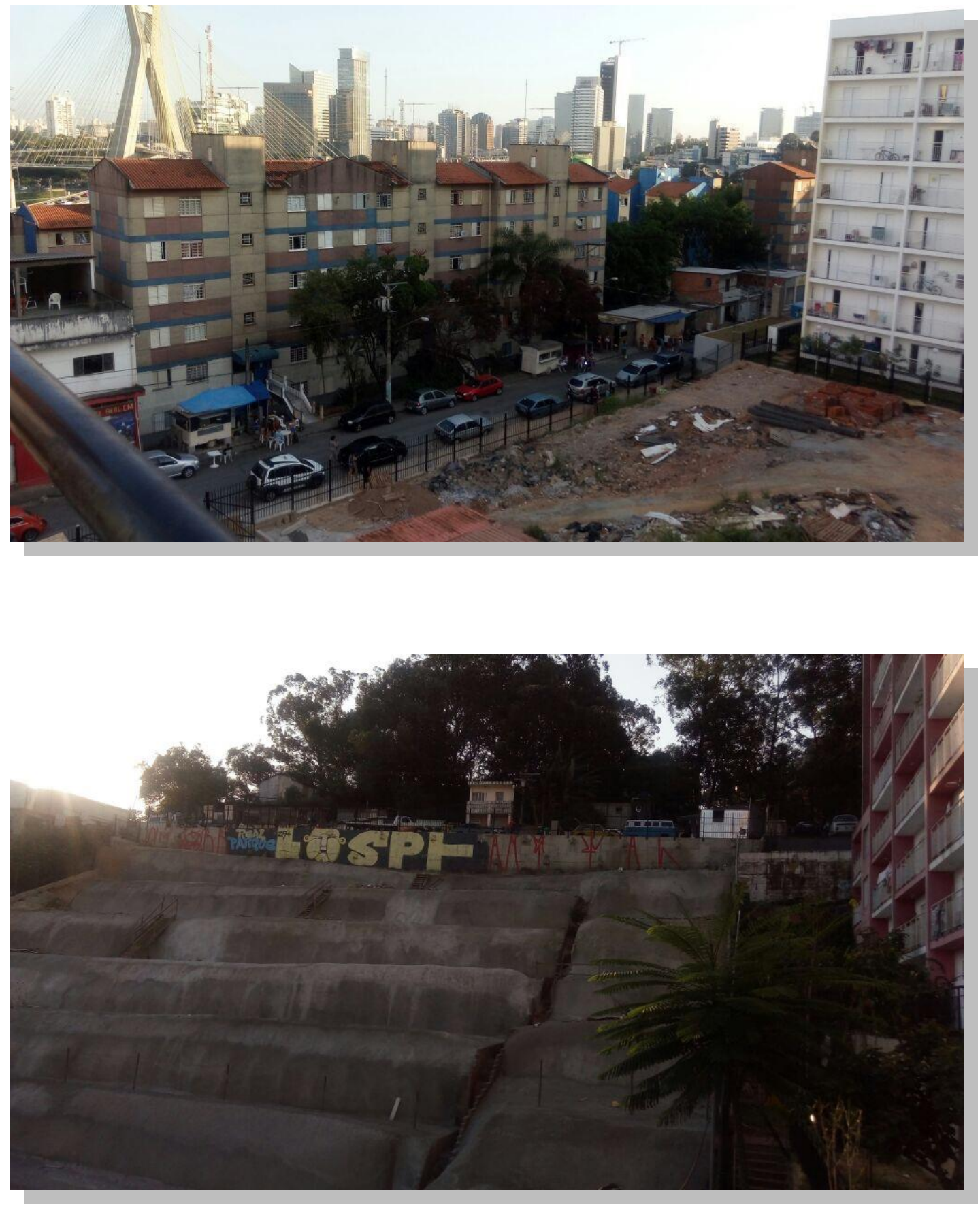

Foto 25 a 28: Área do mirante ainda desocupada e onde os moradores reivindicam a construção de infraestrutura para a comunidade

\section{Fotos: Tiago Prado}




\subsection{LUGAR, PERTENCIMENTO E IDENTIDADE}

Nas falas dos moradores, particularmente nas entrevistas e grupos focais, é possível perceber a relação direta que estabelecem com o lugar em que vivem. Durante a construção dos condomínios ou devido a outras situações vivenciadas na comunidade, várias famílias foram realocadas, como a família de uma das moradoras participante do grupo focal, que teria ficado por nove anos em um alojamento precário próximo à Marginal do Rio Pinheiros, após um incêndio ocorrido em 2001. A família voltou para localidade do Real Parque em 2010, mas enfrentou "a burocracia" para conseguir retornar ao seu local de origem. Outras falas também revelam as dificuldades envolvidas no processo de realocação e, posteriormente, no retorno à comunidade, ao lugar que pertecem.

A revisão da bibliografia evidencia que a expressão "lugar" possui diferentes significados e entendimentos, como espaço ocupado, pequenas áreas, localidades, pontos de observação, região de referência, entre outros (MACHOSIKI, 2015). No entanto, o conceito de lugar para a Geografia é alvo de um debate mais específico e ganha novos contornos, ainda que não haja consenso. A compreensão sobre o conceito de lugar, neste campo de conhecimento, dependerá da abordagem empregada na utilização do termo, bem como da corrente de pensamento adotada (HOLZER, 1999). Atribui-se a Carl Sauer a primeira grande contribuição para a valorização do conceito de lugar. Para este autor, a paisagem cultural é o que define o estudo da Geografia e o sentido do lugar estaria vinculado à ideia de significação dessa paisagem em si (HOLZER, 1999). Como reconhece Holzer (1999), desse entendimento o termo lugar foi sendo vinculado não ao local, mas ao significado específico, ou seja, aos atributos relativos e únicos de um dado ponto do espaço.

Outros autores também vão explorar essa compreensão de lugar, dentro de uma perspectiva fenomenológica, e entendendo a geografia como aquela vivida em ato, a partir da exploração do mundo, olhando a ligação do homem com sua terra natal como "a relação do homem com a Terra [...] como modo de sua existência e de seu destino" (DARDEL, 2011 p. 2).

Para Tuan, todos os lugares são pequenos mundos: o sentido do mundo, no entanto, pode ser encontrado explicitamente na arte mais do que na rede intangível das 
relações humanas. Lugares podem ser símbolos públicos ou campos de preocupação (fields of care), mas o poder dos símbolos para criar lugares depende, em última análise, das emoções humanas que vibram nos campos de preocupação (TUAN, 1979 p.421).

Uma segunda perspectiva do autor sobre o lugar é como localização: "(...) o lugar é uma unidade entre outras unidades ligadas pela rede de circulação; (...). O lugar, no entanto, tem mais substância do que nos sugere a palavra localização: ele é uma entidade única, um conjunto "especial”, que tem história e significado. O lugar encarna as experiências e aspirações das pessoas. O lugar não é só um fato a ser explicado na ampla estrutura do espaço, ele é a realidade a ser esclarecida e compreendida sob a perspectiva das pessoas que lhe dão significado" (TUAN, 1979 p. 387).

Assim, pode-se entender o Real Parque como um pequeno mundo, com características próprias, necessidades próprias, lógicas sociais, um entendimento de identidade que só se aplica àqueles moradores. Daí a importância em compreender a relação que os moradores têm com esse local, entendendo o processo histórico que os levou até este momento e os fatores que configuram o cotidiano destas pessoas.

Prince (1961) dizia que a Geografia deve evocar o "gênio do lugar". A personalidade, ou espírito, é resultante das qualidades físicas do sítio e das modificações que lhe imprimem as sucessivas gerações humanas (TUAN, 1979). Para Pocock, no entanto, apesar de há muito tempo se reconhecer que os lugares possuem personalidades, estas: "[...] são complexas e mudam segundo os que percebem. Existe um evidente contraste entre aquele que percebe como visitante, que observa - que vê a cena superficialmente - e aquele que está "em casa" e que experimenta o lugar" (POCOCK, 1981 p. 342).

A perspectiva sobre pertencimento tem sido destacada nos estudos relacionados ao ambiente, baseada em ideias como a de que o conhecimento é local porque é inerente à atividade de habitar a terra, que de fato cria o lugar e de que, ao criar os lugares, essa atividade também faz os habitantes serem daqueles lugares - ela os torna locais. As pessoas pertencem às localidades e ambientes em que cresceram, tanto quanto estes pertencem a elas (INGOLD, KURTILLA, 2000). 
Segundo Ingold, o lugar que ele atribui ao ser humano no ambiente-mundo é o de um ser imerso no fluxo da vida e dependente dos processos e movimentos dos materiais que constituem nossos corpos e nossas mentes, com os quais traçamos as linhas de nossa história natural e cultural sem solução de continuidade (INGOLD, 2000). Trata-se de conhecimento que não é do tipo formal e autorizado, transmissível em contextos fora de sua aplicação prática. Ao contrário, é baseado em sentimento, constituído de habilidades, sensibilidades e orientações desenvolvidas através de longa experiência de condução da própria vida num ambiente particular (INGOLD, 2000).

Desde essa perspectiva, a análise das narrativas buscou entender as conexões estabelecidas com o lugar a partir daquele que "está em casa", que experimenta no seu cotidiano o lugar. E as impressões e percepções desse lugar, como a análise revela, variam.

A existência de uma comunidade de Pankarurus dentro do Real Parque é destacada, por exemplo, quando uma moradora do grupo focal misto se refere ao grupo como "muito mais unido", que "corre atrás" dos problemas e necessidades, por meio de cobranças e abaixo-assinados. Para além desse grupo, outras manifestações são citadas nas falas, evidenciando que parte dos moradores se preocupa em "melhorar o lugar onde vive, criando e desenvolvendo opções para que a comunidade cresça". Uma das moradoras lembra que é preciso sempre, em cada reunião realizada, fazer atas para que tudo aquilo que for discutido e levantado seja registrado e cobrado posteriormente. Nas narrativas, é possível extrair também a percepção dos moradores de que não há necessidade de sair da comunidade para buscar lazer ou alternativas que trariam mais "felicidade"; contudo revelam que deveria haver mais opções de recreação e formas de lazer oferecidas no lugar onde vivem. "Precisamos de alternativas culturais dentro da comunidade, como diversidade nos grupos, com opções culturais, ligadas à música, dança, grafite, percussão, grupos de leitura, artes marciais, futebol, entre outros”, destaca um jovem integrante do grupo de dança de rua, participante de um dos grupos focais.

Nas pesquisas de campo, foi possível observar o quanto os moradores são ligados ao lugar em que vivem. "Viver no Real Parque é muito bom, é como se fosse uma cidade do interior, onde conhecemos muitas pessoas, podemos parar para conversar 
com os vizinhos, ajudar em problemas cotidianos, é como se fosse uma grande família, com tantas coisas em comum", fala de uma moradora durante entrevista individual. Já para outro morador, que participou do grupo focal misto, o processo da construção dos edifícios levou a um "distanciamento" das pessoas, que agora se fecharam em seus próprios prédios e se entendem como diferentes: "Pertenço ao condomínio "A" e tal morador pertence ao condomínio "B", portanto, esta pessoa não é bem-vinda neste prédio". Isso foi também destacado por um jovem integrante do grupo de dança que, por falta de espaço para desenvolver seus ensaios, quando precisa utilizar as quadras dos prédios, enfrenta o problema de não ser bem-vindo nos condomínios aos quais não pertence. Vê-se, assim, que a questão do pertencimento também ganha novas características após o processo de construção dos prédios, fragmentando o lugar e "distanciando as pessoas, perdendo uma das características que definiam o Real Parque antigamente", destaca uma moradora, que participou do grupo focal de jovens.

Outra possibilidade analítica nessa relação indivíduo-lugar pode ser pensada à luz da ideia de identidade. A perspectiva da geografia clássica, marcadamente do século XIX, entendia a identidade como conjunto relacional do lugar e do habitante deste lugar, na profundidade histórica do grupo e de sua relação com o ambiente. Porém, esta concepção de identidade estava fortemente associada às perspectivas naturalistas, como se as sociedades fossem "congeladas" (AMORIM, 2010).

O lugar, produto da experiência pessoal vivida, permeado de dimensões simbólicas, culturais, políticas e sociais, só adquire uma identidade e significado através das intenções humanas atribuídas a ele (LEITE, 1998). Segundo Holzer, a identidade do lugar tem relação com o espírito deste, cujo enraizamento e o sentimento de familiaridade dependem das qualidades físicas e das mudanças que as gerações humanas the atribuem (HOLZER, 1997). Relph menciona que a relação entre o indivíduo e a comunidade com o seu lugar permite e reforça a identidade destes, mesmo com as modificações introduzidas. Para Buttimer, a identidade cultural está intrinsecamente relacionada à identidade com o lugar. As dimensões culturais, emocionais, políticas e biológicas permitem ao indivíduo possuir redes de interações baseadas no lugar. Mesmo diante das transformações no lugar, para o indivíduo e para a 
comunidade, a sensação de que as características antigas permanecem, reforçam a identidade com o lugar (BUTTIMER, 1982).

A identidade de um lugar depende tanto das experiências intersubjetivas como das aparências. Ferreira, com base nas fundamentações de Relph, pontua que a identidade deveria ser considerada a partir de quatro pontos: 1. Seus componentes constituintes; 2. Suas formas e níveis de externidade (outsideness) e internidade (insideness) da identidade com o lugar; 3. Das ligações das imagens de lugares com sua identidade; 4. Dos modos pelos quais as identidades se desenvolvem, são mantidas e se modificam (FERREIRA, 2002). Ainda para Ferreira, a localização física estática, as atividades, os significados e o espírito do lugar compõem a sua identidade. "Quanto mais profundamente se está dentro de um lugar mais forte a identidade com ele" (FERREIRA, 2002, p. 48).

Para Carlos, o lugar seria a base da reprodução da vida, podendo ser analisado pela tríade habitante-lugar-identidade (CARLOS, 1996). A identidade, o sentimento de pertencimento e o acumulo de tempos e histórias individuais constituem o lugar. Este guarda em si o seu significado e as dimensões do movimento da história, apreendido pela memória, através dos sentidos. Há uma multiplicidade de relações e especificidades da produção espacial global (SANTOS, 1982). Castells considera a identidade como um processo de construção de significados pautados em "conjuntos de atributos culturais inter-relacionados, os quais prevalecem sobre outras fontes de significados". Essa construção da identidade está articulada com as relações de poder. Na concepção do autor, a identidade deve ser compreendida como processo culturalmente construído e repleto de significados (CASTELLS, 2000).

Sobre identidade, Carrano (2008) define que a descontinuidade é um traço marcante da vida individual contemporânea. O indivíduo não apenas reproduz os traços de hereditariedade e tradição de sua comunidade de origem, mas vive continuamente a capacidade de redefinir-se. Neste sentido, a resposta sobre "o que eu sou" não resulta apenas de um condicionante social, externo, mas está associada à capacidade individual que os indivíduos têm de se definirem e se diferenciarem uns dos outros (CARRANO, 2008). Como mencionado anteriormente, um dos pontos positivos destacados nas narrativas dos moradores mais antigos, era a questão de viver em grupo, uma 
comunidade que "por possuir tantos problemas, levava a uma união para resolver os mesmos", aproximando assim os moradores em redes de solidariedade. Essa identidade entre os moradores vem se desfazendo, na perspectiva dos entrevistados, devido especialmente à fragmentação do espaço nesta nova estrutura urbana de prédios.

Como argumenta Carrano (2008), um dos desafios da contemporaneidade tem sido a construção da unidade social em sociedades marcadas por significativas diferenças e desigualdades pessoais e coletivas. Escutar a si e ao outro se torna, portanto, a condição para o reconhecimento e comunicação (CARRANO, 2008). Neste sentido, é preciso refletir sobre um dos fundamentos para as reuniões dos moradores, sejam elas reuniões de condomínios ou mesmo as reuniões quinzenais do Projeto Casulo: escutar os problemas mútuos e tentar solucioná-los de forma mais ordenada, elencando-os e propondo soluções em comunidade. Em uma das reuniões observadas do Projeto Casulo, foi lembrado que o problema que eles enfrentavam era o de "como atrair os moradores e mostrar a necessidade da participação dos mesmos em reuniões, que trariam melhoras significativas na qualidade de vida da comunidade". "Há uma falta de interesse generalizado por grande parte dos moradores, que não se entendem como fundamentais para dar continuidade à qualidade do Real Parque, muitos moradores não se julgam importantes para o todo", destaca um morador durante o grupo focal misto. Cabe ressaltar que essa ausência de envolvimento e disposição também foi observada na dificuldade de realizar um grupo focal com síndicos, que não se mostraram interessados em participar do estudo, contribuir com ideias, destacar os problemas dos seus prédios, ou mesmo compartilhar suas aflições e necessidades.

Segundo Bauman, a construção da identidade é um processo sem fim, passível de experimentação e mudança, de caráter não definitivo, fazendo com que ela seja construída continuamente ao longo da vida (BAUMAN, 2003). Lestinge acredita que com o sentimento de pertencimento torna-se possível a libertação das pessoas. Esse sentimento levará o indivíduo a se enraizar, a se formar como um ser, nutrir-se do que há ali criando a sua identidade. Com uma identidade firme e consistente ele poderá passar pelo desenraizamento, pois irá para qualquer lugar que seus princípios sempre estarão presentes, seus referenciais serão claros e sua essência consistente, libertando-o. Como se fosse um movimento, uma práxis da identidade (LESTINGE, 2004). 
Essa aparente apatia dos moradores do Real Parque em se envolverem mais ativamente nas reuniões e discussões dos problemas enfrentados pela comunidade não é condição exclusiva da localidade estudada. Ao contrário, pode ser entendida como uma das características das sociedades contemporâneas, dessa modernidade líquida, como aponta Bauman (2001), cujo estágio de fluidez tem como efeitos colaterais a desintegração da rede social, a derrocada das agências efetivas de ação coletiva, o desengajamento e a arte da fuga.

Sobre a questão da apatia social, Oliveira (2013) lembra que o termo foi bastante utilizado nos séculos XIX e XX para explicar aspectos da vida cotidiana em culturas pré-industriais. O termo apatia é derivado do Grego "pathos" que significa paixão. A palavra apatia indicaria assim falta de paixão, em outras palavras uma diminuição das atividades dirigidas a uma meta. Há falta de motivação, de interesse, geral ou direcionado, à aprendizagem de novos conhecimentos ou experiências, além de uma despreocupação consigo mesmo. Para Oliveira (2013), a apatia está relacionada à falta de produtividade, esforço e iniciativa, diminuição das socializações, aumento dos comportamentos de submissão ou dependência. Além disso, nota-se a falta de reações emocionais frente a surpresas positivas ou negativas, falta de planejamento afetivo e de excitação. A apatia também pode ser compreendida como um dos efeitos da exposição à situação de incontrolabilidade (OLIVEIRA, 2013). No caso do Real Parque, parece haver ainda uma aposta forte, por parte da maioria dos moradores, de que as soluções para seus problemas devem vir ainda somente do Estado. Parece haver também, dialogando com os apontamentos de Bauman (2001), uma visão de si mesmos enquanto indivíduos e não cidadãos. Bauman lembra que há uma diferença importante a ser pensada nesta nova fase da modernidade: cidadãos são diferentes de indivíduos. Cidadão tende a buscar seu próprio bem-estar através do bem-estar da cidade, o indivíduo é cético ou prudente em relação à causa comum, ao bem comum, à sociedade justa. A ideia de interesses comuns passa a ser a de permitir que cada indivíduo satisfaça seus próprios interesses e o poder público, para isso, deve apenas observar os direitos humanos, permitir que cada um siga seu próprio caminho e que todos o façam em paz. A individualização leva então à lenta desintegração da cidadania. O público passa a ser colonizado pelo privado, o interesse público passa a ser reduzido à curiosidade sobre as vidas privadas de figuras públicas, a arte da vida pública passa a 
ser reduzida à exposição pública das questões privadas e confissões de sentimentos privados (Bauman, 2001).

Nas falas dos moradores nos grupos focais e nas entrevistas individuais, é possível extrair também um sentimento de exclusão entre eles, particularmente uma percepção de que são excluídos da região onde a comunidade está inserida. Há também a percepção de que o processo de reurbanização contribuiu para um possível "desmanche" das redes estabelecidas - com vizinhos que foram separados e hoje vivem em diferentes condomínios, ainda que dentro da mesma localidade: a comunidade, na percepção dessas pessoas, perdeu sua característica de "cidadezinha do interior". Contudo, o processo de reurbanização, ao mesmo tempo, propiciou novas redes de contato e, na perspectiva de um morador, contribuiu "para que as pessoas pudessem se conhecer", ainda que o fato de que as quadras dos prédios só possam ser utilizadas pelos próprios moradores dos prédios seja uma queixa comum. Essa limitação, no entendimento de alguns moradores, interfere nas atividades culturais e de lazer, nas aproximações entre os residentes; ao mesmo tempo, revela que parte dos entraves vivenciados por eles são resultados também de suas próprias decisões. O querer permanecer "vivendo em comunidade" é, algumas vezes, impedido pela própria comunidade.

As narrativas revelam também que se antes os moradores enfrentavam o problema da passagem pelos becos da favela, hoje lidam com dificuldades de acesso aos prédios. Uma moradora do grupo focal misto, por exemplo, relata que foi contemplada com um apartamento onde teria que subir escadas. Por ter um filho cadeirante, isso ficaria inviável. Contudo, mudar de apartamento não foi uma tarefa fácil. Segundo ela, "demorou muito para que algo fosse feito, pela burocracia no processo de pedido de um apartamento térreo". Ela ainda reclama hoje da falta de rampas de acesso, do fato de não haver elevadores nos prédios (promessa, segundo ela, não cumprida) e da quantidade grande de carros e lixo nas ruas, revelando as potenciais dificuldades do lugar onde vive.

Tempos nos deslocamentos entre a casa, o local de trabalho e estudo e acesso a serviços de saúde também são queixas comuns entre os moradores. Um participante do grupo focal de jovens, por exemplo, destaca que se escolas, postos de saúde e opções de 
lazer fossem criados na comunidade, muitos dos deslocamentos dos moradores seriam diminuídos. Isso implicaria, na sua percepção, numa diminuição no peso de investimentos em mobilidade urbana, que hoje é de responsabilidade do próprio Estado.

Se o lugar onde vivem passou por uma transformação, essa mesma mudança não teria alcançado outras dimensões. A análise das falas mostra o sentimento presente entre os moradores de que teriam ganhado uma moradia digna, mas ainda continuariam a viver como "favelados em seu comportamento", como mostra a frase "a estrutura dos condomínios não entra na cabeça das pessoas”. Neste ponto, uma moradora do grupo focal misto destaca uma "forte identidade com a favela", ressaltando a pouca participação efetiva dos moradores em reuniões de condomínio, que "favoreceriam e muito as melhoras que tanto são cobradas". A frase "nós saímos da favela, mas a favela não saiu das pessoas" foi repetida algumas vezes pelos moradores durante as entrevistas em grupo.

Milton Santos estabelece que há uma relação entre espaço enquanto instância social e destaca que quando a sociedade age sobre o espaço, ela não o faz sobre os objetos como realidade física, mas como realidade social, formas-conteúdo, isto é, objetos sociais já valorizados aos quais ela (a sociedade) busca oferecer ou impor um novo valor (SANTOS, 1996). A ação, na perspectiva desse autor, se dá sobre objetos já agidos, isto é, portadores de ações concluídas, mais ainda presentes. Esses objetos da ação são, desse modo, dotados de uma presença humana e por ela qualificados. A dialética se dá entre uma situação nova e uma "velha" situação, um presente inconcluso querendo realizar-se sobre um presente perfeito. A paisagem é apenas uma parte da situação (SANTOS, 1996).

Essa reflexão do autor é válida para refletir sobre a fala de uma moradora participante do grupo focal de jovens, acerca das abordagens policiais aos jovens moradores da localidade. Segundo ela, particularmente à noite, jovens que voltam da escola são abordados de forma truculenta pelos policiais. Ela apenas observa, do seu comércio (um Petshop, nas imediações do Real Parque), sem nada poder fazer. Tais abordagens, na sua perspectiva, refletem um "generalismo pelo possível risco que uma comunidade pobre oferece", independentemente das suas características e mudanças. Ao montar seu comércio na localidade em que viveu sua vida, ainda que em outro local 
mais distante o negócio pudesse talvez ser mais rentável, ela acredita retribuir o lugar em que cresceu, fez amigos e tem suas relações interpessoais. Escolher outro local, em sua visão, levaria a uma "perda da essência do que a formou como ela é hoje".

As fotos a seguir, de 29 a 31, complementam essa análise e representam as condições de lugar, pertencimento e identidade observadas durante a realização das visitas a campo no Real Parque e destacadas neste subcapítulo, como o "Bar da Cida Pankararu" (foto 29), a questão das quadras e do acesso (foto 30), a dificuldade de acesso e mobilidade dentro do Real Paque (foto 31).

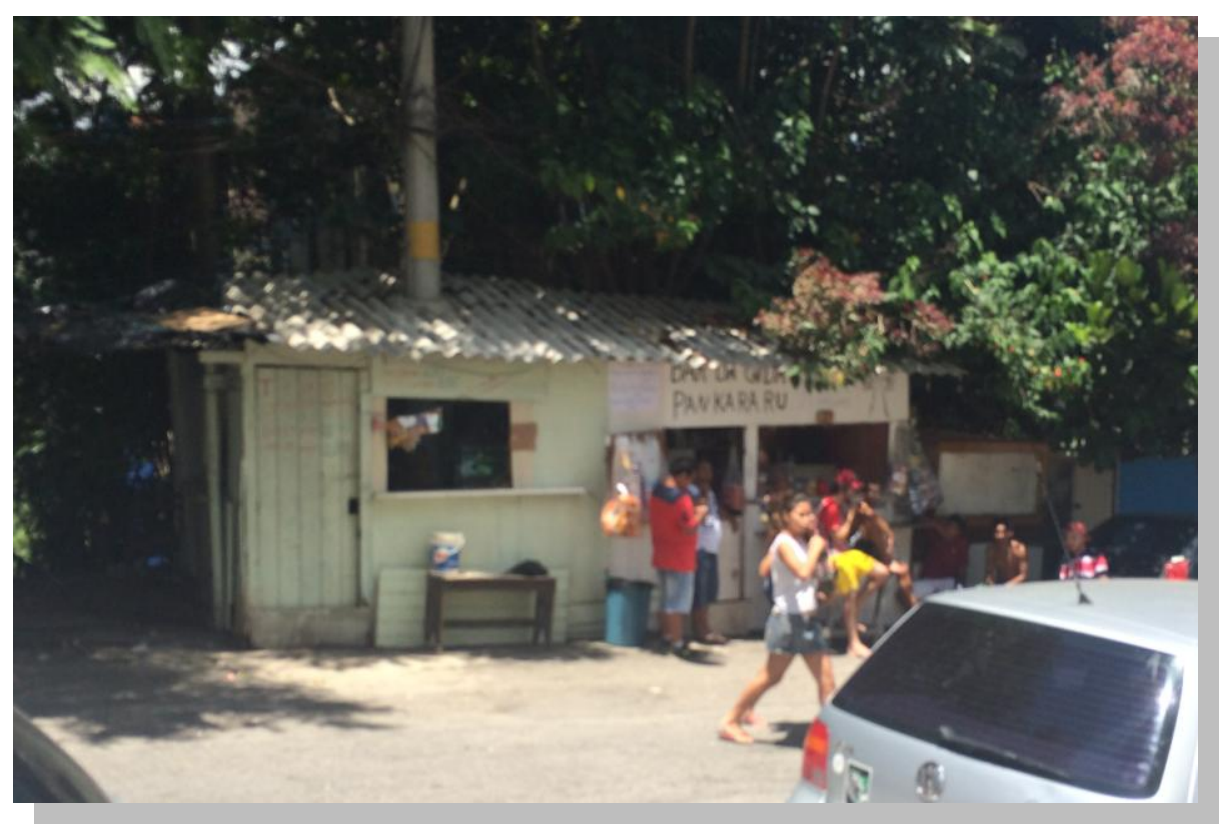

Foto 29: "Bar da Cida Pankararu"

\section{Foto: Tiago Prado}




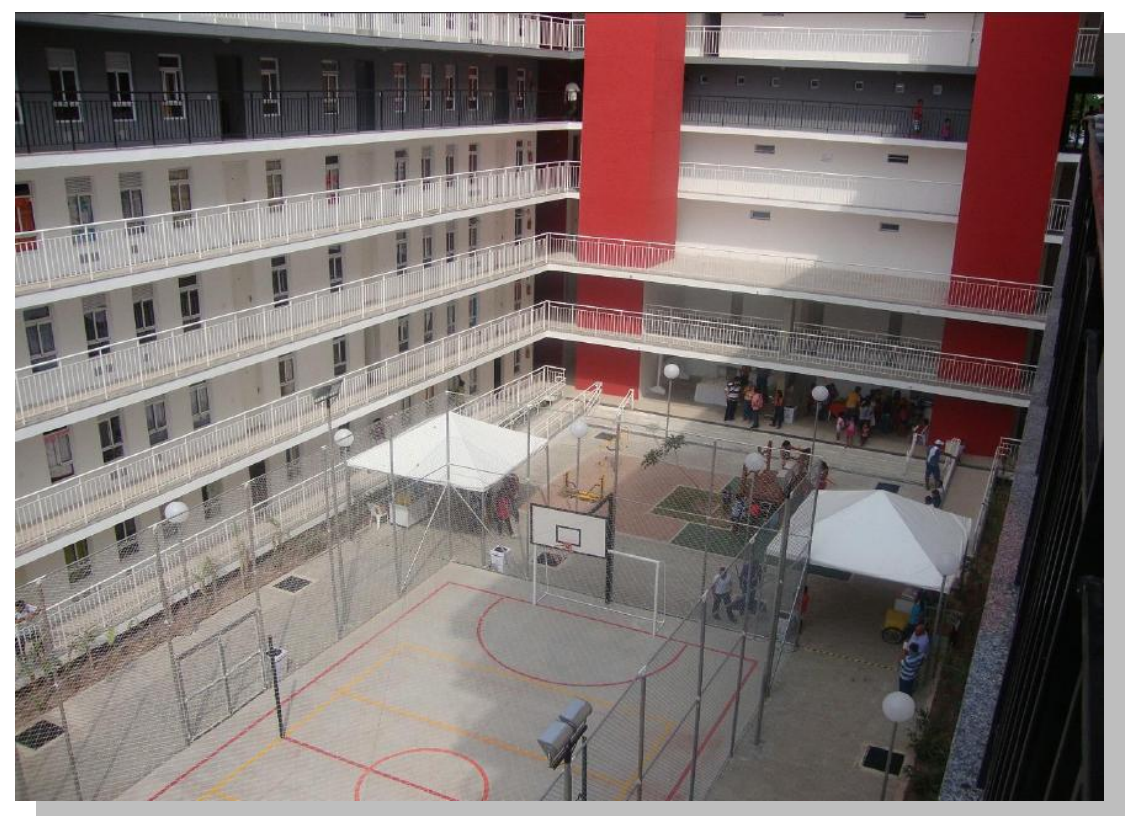

Foto 30: Condomínio com a quadra

\section{Fonte: SEHAB, 2009}

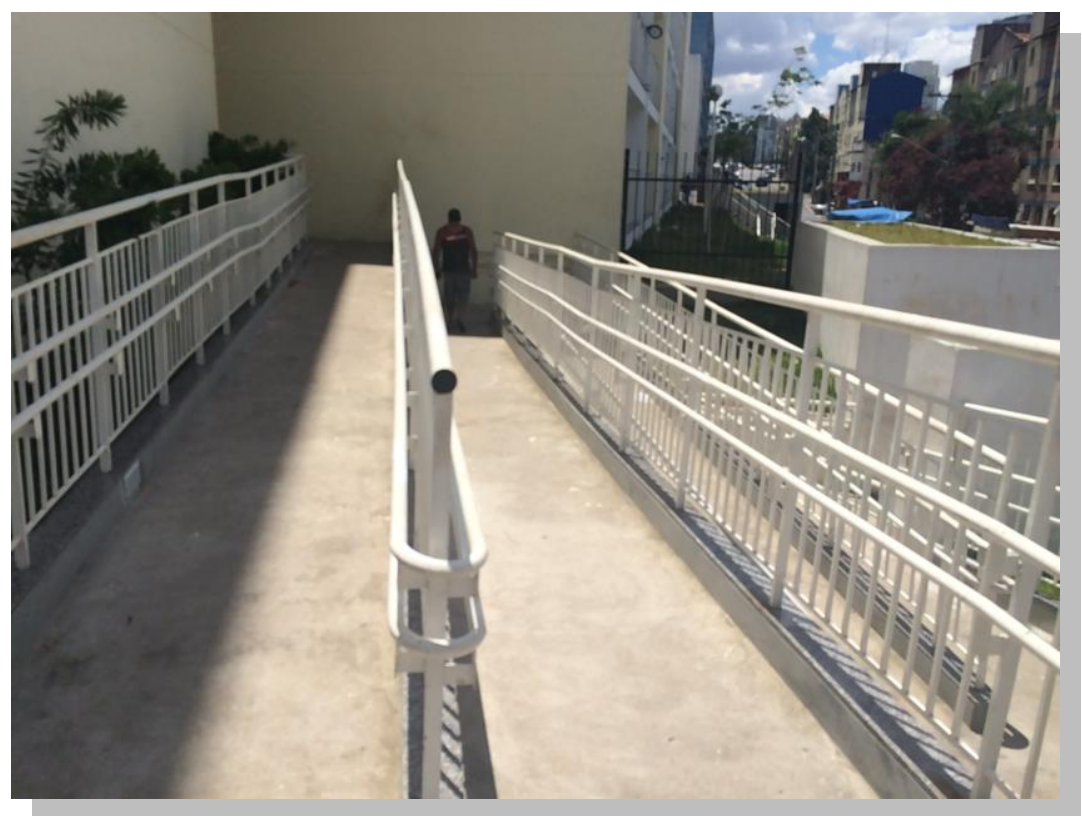

Foto 31: Rampa de acesso em um dos condomínios

\section{Foto: Tiago Prado}




\subsection{DEMANDAS E NECESSIDADES PARA MELHORAR A QUALIDADE DE VIDA DOS MORADORES}

Qualidade de vida é um termo de difícil conceituação, e, durante as últimas décadas, apesar dos debates, ainda não há um conceito único (KLUTHCOVSKY, 2007). O termo já foi usado para criticar políticas, nas quais o objetivo era o crescimento econômico sem limites. Com o passar dos anos, o conceito se ampliou, significando, além do crescimento econômico, o desenvolvimento social, como educação, saúde, lazer etc. Recentemente, tem-se valorizado fatores como satisfação, qualidade dos relacionamentos, realização pessoal, percepção de bem-estar, possibilidades de acesso a eventos culturais, oportunidades de lazer, entre outros, como a felicidade, solidariedade e liberdade. Assim, há uma crescente mudança dos enfoques quando se fala em qualidade de vida, com a intenção de considerar, além dos aspectos objetivos, também os aspectos subjetivos do tema (KLUTHCOVSKY, 2007).

Embora não haja consenso sobre o conceito de qualidade de vida, um grupo de especialistas da Organização Mundial da Saúde, de diferentes culturas, num projeto colaborativo multicêntrico, obteve três aspectos fundamentais referentes ao construto qualidade de vida: a subjetividade, a multidimensionalidade (inclui, pelo menos, as dimensões física, psicológica e social) e a bipolaridade (presença de dimensões positivas e negativas) (FLECK, 1999 apud KLUTHCOVSKY, 2007). Este conceito também pode mudar partindo do pressuposto de que a avaliação da qualidade de vida pode se alterar, em função do tempo, local, pessoa e contexto cultural.

É possível destacar alguns elementos sobre qualidade de vida que surgiram nas entrevistas, grupos focais e reuniões do Projeto Casulo serão destacados a seguir, como: satisfação, qualidade dos relacionamentos interpessoais, realização pessoal, percepção de bem-estar, possibilidade de acesso a eventos culturais, oportunidades de lazer, felicidade em viver em comunidade, cooperação mútua e solidariedade, liberdade, entre outros.

Para os moradores, os prédios construídos contribuíram para proporcionar maior segurança do ponto de vista de materiais inflamáveis potenciais a eventos como incêndios, que eram comuns na antiga favela. Contudo, o risco ainda existe, já que um morador relata que, recentemente, um residente esqueceu o gás ligado e os vizinhos, ao 
sentirem o forte cheiro, começaram a bater em sua porta. Foi necessário entrarem a força, pois o risco de explosão era considerado alto. Mesmo com a construção de moradias mais seguras e de menor risco, a responsabilidade individual de viver em grupo é apontada como relevante na garantia de uma melhor qualidade de vida.

O saneamento básico é citado em diversas falas, tanto nas reuniões como nas entrevistas individuais, apontado como ponto positivo na qualidade de vida da comunidade. O mau cheiro dos esgotos a céu aberto, presença e criação de vetores de doenças fazem parte dos problemas passados, que não se reproduzem após a urbanização. O acesso à água que era complicado, pois sem a infraestrutura de abastecimento muitos moradores tinham de se deslocar para buscarem o recurso, ou mesmo a qualidade que era prejudicada pelas instalações irregulares, hoje são também problemas percebidos como do passado.

A qualidade de vida do ponto de vista da moradia é ponto fundamental para os residentes. O medo e a incerteza com que viviam os moradores em dias de chuva e fortes ventos não fazem mais parte do cotidiano atual. Para eles, a situação dos barracos era de completa insegurança e instabilidade, pois eram construções rudimentares, deixando uma "tensão e insegurança presente a todo instante", como lembra um morador participante do grupo focal misto.

A criação de programas de educação e cultura para que os jovens possam ser tirados das ruas e do ócio foi lembrada nas entrevistas e apontada como ponto importante na qualidade de vida dos moradores. Também foi levantado o problema da educação precária das escolas, como a falta de professores, falta de estrutura para que os alunos possam "aprender e crescer como cidadãos", entendendo o que é viver em sociedade e a respeitar as diferenças. A educação é a grande aposta para os moradores, já que traria para esses jovens um "foco de vida, algo para lutar, para se esforçar, para buscar", bem como preparação para o mercado de trabalho e crescimento intelectual. Essa questão foi citada em diversas oportunidades no decorrer da pesquisa em campo.

Uma proposta que surgiu durante as reuniões do Projeto Casulo, focada na melhoria da qualidade de vida e inserção dos moradores em uma atividade rentável, foi a de reciclagem de resíduos. A mudança no hábito dos moradores com relação ao 
destino do seu lixo traria benefícios tangíveis para a comunidade. $\mathrm{O}$ dinheiro que esta atividade renderia poderia ser usado para investimentos para a própria comunidade, melhoraria as condições de limpeza dos condomínios, pois seria uma ação conjunta dos moradores, criando uma prática de educação ambiental no longo prazo. Hoje, o acúmulo de lixo nas imediações é apontado como ponto negativo e uma demanda a ser solucionada: "moradores jogam lixo nas escadas dos prédios, urinam nas escadas ou nos cantos dos edifícios, jogam lixos nas ruas e nos corredores, prejudicando o bom convívio em vizinhança, pois sempre sobra para alguns limpar a sujeira dos outros", lembra uma moradora durante a reunião do Projeto Casulo.

Outra sugestão de um participante do grupo focal misto, ainda na perspectiva da qualidade de vida, foi a de desenvolver trabalhos na comunidade feitos com jovens e crianças. Hoje, segundo o morador, ele tem chamado crianças e jovens para que juntos façam algumas atividades visando o bem-estar da comunidade, como carpir mato, limpar entulhos em terrenos ou nas ruas, varrer os prédios, retirar o lixo do chão.

O conjunto das narrativas revela que os moradores gostam de viver no Real Parque, porém muitas vezes se sentem "reprimidos socialmente" pelos condomínios de alto padrão do entorno, cercados por muros, guaritas, numa paisagem excludente e pouco acolhedora. Ao pensarem nas demandas para a localidade, suas percepções são comuns: melhorar a mobilidade urbana e ter uma melhor infraestrutura de saúde, cultura, lazer, e mais oportunidades próximas de trabalho.

Para saírem do Real Parque, os moradores relatam poucas opções de transporte, que ficam ainda distantes, e a necessidade de uso de diversas linhas de ônibus para se deslocarem para áreas adjacentes da cidade. Como não existem muitas linhas para outras regiões de São Paulo, a viagem torna-se longa, o que contribuiu para que "a comunidade se feche em si mesma" e se isole, não integrando os residentes com o restante da cidade, dificultando o acesso a pontos turísticos e culturais ${ }^{18}$, como destaca um jovem durante o grupo focal.

\footnotetext{
${ }^{18}$ Linhas de ônibus que servem o eixo mais central do Real Parque: Linha: 6418-10 Real Parque-Brooklin Novo (Operação de segunda à sexta: 04:30 -23:20, não opera aos finais de semana e feriados); Linha: 6418-31 Real Parque-Brooklin Novo (Operação de segunda a sexta: 06:30-16:30, não opera aos finais de semana e feriados); Linha: 746R-10 Real
} 
Destacam também certo medo de caminharem nas imediações pela segregação espacial dos prédios e falta de pessoas nas ruas, o que gera preocupações com assaltos. $\mathrm{O}$ acesso à saúde também é mencionado em todas as entrevistas, particularmente a necessidade de um posto de saúde mais próximo dos moradores, ou uma UBS integral, assim como comércios e espaços de lazer do tipo indor - fato mencionado, sobretudo pelos jovens que integram um grupo de dança da comunidade.

Outra proposta levantada pelos moradores no grupo focal misto está relacionada a um plano de integração de grupos distintos, que desenvolveriam atividades em conjunto, como grupos de música, de dança, leitura, futebol, entre outros. Essas atividades poderiam ampliar o acesso de mais jovens da comunidade, que se interessariam pela diversidade de opções oferecidas do ponto de vista cultural e da educação.

Atualmente, em parceria com o Colégio Santi (no Paraíso), a comunidade tem tido cursos periódicos como design e realização de workshops. O Projeto Casulo também realiza atividades a cada 15 dias, como sarau, cinema e oficinas para desenvolvimento profissional. Ainda que vários jovens da comunidade participem dessas iniciativas, eles destacam que um dos problemas é a perda de interesse por parte dos moradores, que participam uma vez e depois desistem das próximas atividades.

Hoje, para a maior parte dos jovens que participaram do grupo focal, a opção de lazer é frequentar o Shopping Santo Amaro ou Shopping Boa Vista; contudo, estas são possibilidades restritas do ponto de vista financeiro e da dificuldade de acesso, já que poucas linhas de ônibus servem o Real Parque e a mobilidade fica limitada ou o valor do deslocamento se eleva, no caso da opção pelo trem ou metrô. Eles revelam também enfrentar o problema de preconceito por suas condições socioeconômicas.

Nos grupos focais, foi citado que crianças e jovens têm o desejo de conhecer a cidade, sair da comunidade em que vivem para "não ficarem presas nas mesmas coisas"; porém, a falta de oportunidades e falta de iniciativa ou interesse por parte dos

Parque-Santo Amaro (Operação de segunda à sexta: 04:30-23:40, sábados: 04:30-23:15, domingos e feriados: 04:40-23:15); Linha: 807M-10 Terminal Campo Limpo-Shopping Morumbi (Operação de segunda à sexta: 04:00-23:30, sábados: 04:00-22:45, domingos $e$ 
pais ou responsáveis, ou mesmo das escolas, inviabilizam as tentativas de se apropriarem da cidade onde vivem. Ainda que a inclusão digital e a facilidade de acesso à internet, especialmente com smartphones, possibilitem acesso à informação, a divulgação do que a cidade oferece com opções de lazer e passeios culturais gratuitos ainda não tem o alcance esperado. "Existe um descaso muito grande por todas as partes a respeito das comunidades mais pobres", lembra um jovem morador no grupo focal. "Não existe um apoio de fora da comunidade e os poucos moradores que têm esta oportunidade de conhecer a cidade, não conseguem divulgar no Real Parque”. Para ele, é necessário um agente externo para "convencer" os moradores da importância de se integrarem com o restante da cidade de São Paulo. As fotos a seguir representam alguns dos aspectos tratados neste subcapítulo, como problemas com geração e coleta de resíduos (foto 32), e o isolamento espacial da comunidade, cercada por muros, que agrava o sentimento de exclusão e segregação dos seus moradores (fotos 33 e 34).

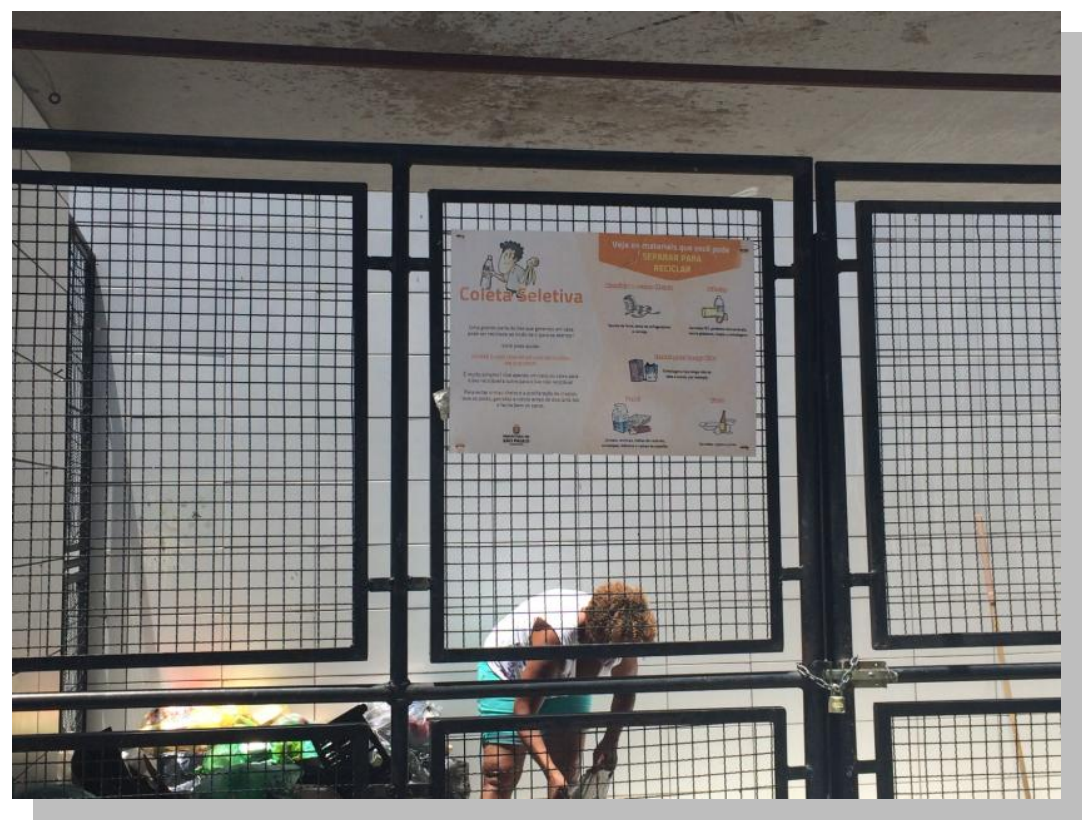

Foto 32: Placa sobre coleta seletiva em uma lixeira, explicando o seu funcionamento Foto: Tiago Prado

feriados: 04:30-23:20). Disponível em: http://www.sptrans.com.br/itinerarios/. Acesso em: 15 de Mai. 2017. 

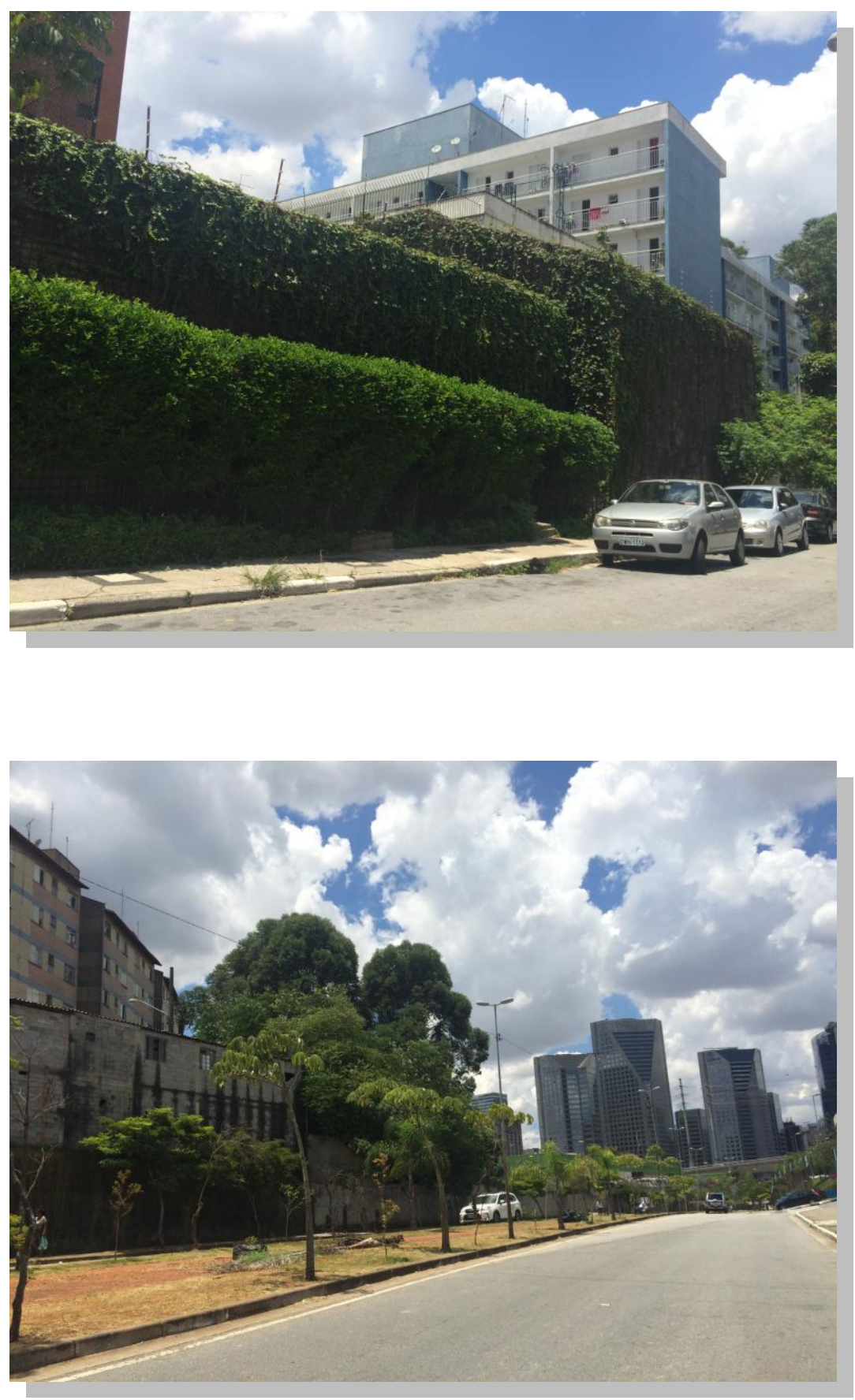

Foto 33 e 34: Muros que segregam o Real Parque dos condomínios de alto padrão Fotos: Tiago Prado 


\section{CONSIDERACÕES FINAIS}

Da favela que emergiu na década de 1950, caracterizada por seus contrastes, cercada de condomínios de alto padrão, com tensões cotidianas impulsionadas pelas diferenças marcantes entre a ocupação irregular e seu entorno, a região do Real Parque, ao ser contemplada com o projeto de reurbanização liderado pela Prefeitura Municipal de São Paulo, evidencia uma mudança nos padrões da política habitacional da cidade. A localização desse novo empreendimento em uma área valorizada, com a construção de unidades habitacionais que contemplem todas as famílias cadastradas, desapropriação de terrenos na área (para construção de edifícios evitando novas remoções de moradores) e melhora da qualidade dos conjuntos habitacionais, pode ser pensada à luz de suas características estéticas e arquitetônicas. Contudo, um estudo mais focado nas percepções dos moradores acerca desse processo de reurbanização, como a pesquisa realizada, revela uma mescla de experiências associadas às mudanças vivenciadas, que reverberam, inclusive, em mudanças nas suas percepções sobre condições de vulnerabilidades, demandas e necessidades locais.

Certamente o projeto arquitetônico trouxe benefícios aos moradores. O receio que enfrentavam com relação aos riscos em épocas de chuvas, associados a deslizamentos, desmoronamentos, disseminação de doenças, dificuldade de acesso ao saneamento e outras infraestruturas básicas, como água potável e energia elétrica, além de riscos associados às condições precárias de moradia, permite que sinalizem com facilidade, nas suas falas, os efeitos positivos advindos com o processo de reurbanização.

Agora, vivendo sob a estrutura de condomínios, esses riscos foram minimizados e reduzidos; contudo, outras questões ganham mais visibilidade, como aquelas associadas à mobilidade (com acesso a mais linhas de ônibus e pontos mais próximos, passagem de veículos nas ruas estreitas entre os condomínios); à disponibilidade de comércios locais (hoje, mais concentrados em bares); à limpeza das vias e acessos em

comum e destinação dos resíduos gerados pelos próprios moradores; ao compartilhamento da conta de água; à disponibilidade de mais opções de lazer e melhor oferta de infraestrutura e serviços no local. Ganham visibilidade ainda as preocupações 
com o surgimento de novas ocupações irregulares no entorno, bem como as reproduções de hierarquização e segregação dentro da comunidade, repetindo dinâmicas, tensões e conflitos que marcaram (e continuam a marcar) as relações de vizinhança numa área caracterizada por significativos contrastes.

Viver sob a estrutura de condomínios traz impactos às relações estabelecidas entre os moradores, ora desmanchando ora criando redes estabelecidas, e com o local onde vivem. Ao se fecharem em seus próprios apartamentos e prédios e lidarem com as dificuldades de acesso aos prédios que pertencem a outros condomínios, os moradores também se distanciam, perdendo uma das características que definiam o Real Parque como "uma cidadezinha do interior". Contudo, a nova reconfiguração do local também proporciona um contato de moradores que antes não se conheciam, estabelecendo, assim, novas redes - ainda que motivadas muito mais por aproximações espaciais do que por outras afinidades.

A solução para os problemas e demandas que apontam hoje passa tanto por ações externas e governamentais, mas também por estratégias internas, estas dificultadas pela pouca participação efetiva dos moradores em reuniões de condomínio e outras ações de engajamento e mobilização. Parte da solução também é direcionada à necessária mudança de comportamento, reproduzida na frase "nós saímos da favela, mas a favela não saiu das pessoas", repetida nas falas dos moradores. Há uma expectativa de que os moradores se mobilizem mais para alcançar melhorias na qualidade de vida dos residentes e do local onde vivem. Essas melhorias envolvem, inclusive, a necessidade de se sentirem mais incluídos ao bairro onde estão inseridos e à própria cidade de São Paulo.

Os resultados obtidos e discutidos nesta dissertação evidenciam a relevância de um estudo qualitativo, apoiado em um conjunto de métodos que permitiu uma aproximação maior entre pesquisador e sujeitos da pesquisa, tanto para compreender as potencialidades e limitações do projeto de reurbanização, como para entender que este é um processo de transformação ainda em curso, cujas reverberações no lugar e nos seus moradores continuarão a ser sentidas nos próximos anos.

A urbanização proposta nesta localidade do Real Parque, ainda que possibilite o acesso dos moradores a condições mais dignas de moradia e infraestrutura, não se 
realiza com a mesma qualidade e frequência para todos. Como alerta Rezende (2015), o processo de requalificação urbana permitiu uma valorização imobiliária da área, o que, associada à inexistência ou inadequação de instrumentos efetivos que garantam a inserção e permanência dos moradores no núcleo urbanizado, pode aumentar a expulsão de famílias mais vulneráveis para outras localidades. Acompanhar a continuidade desse processo, a partir das perspectivas exploradas nesta dissertação e de lacunas que permanecem, tendo em vista os limites da pesquisa realizada, é uma via importante para estudos futuros; assim como confrontar a experiência do Real Parque com iniciativas que emergem em outras localidades, nacional e internacionalmente, para pensar em possibilidades de minimizar os efeitos da gentrificação e diminuir segregações especiais.

Cabe ressaltar que os dados gerados e analisados no presente trabalho poderão servir como subsídios para que os próprios moradores e gestores locais, como por exemplo, a subprefeitura do Butantã, possam a partir da compreensão sobre a lógica espacial da região e dos apontamentos da comunidade local pensar e propor investimentos em diversas esferas sociais e urbanas. Os dados da pesquisa serão divulgados e compartilhados com a comunidade do Real Parque, em futura reunião a ser realizada com os moradores. Serão compartilhados também com alguns órgãos públicos, como a SEHAB e a Subprefeitura do Butantã, podendo servir como subsídios para novos projetos a serem desenvolvidos, atendendo também, assim, ao propósito do Mestrado Profissional. 


\section{REFERÊNCIAS BIBLIOGRÁFICAS}

ACHUTTI, Luiz Eduardo Robinson. Fotoetnografia da Biblioteca Jardim. Porto Alegre: Editora da UFRGS/Tomo Editorial, 2004.

ALEXANDER, David. Modelos de vulnerabilidade social a desastres. Revista Crítica de Ciências Sociais, 2011. Artigo. Disponível em: http://rccs.revues.org/113. Acesso em: 30 de jun. 2015.

AMORIM, Viviane Menezes de. Identidades territoriais no cotidiano escolar. Dissertação de Mestrado. Rio de Janeiro: PUC, Departamento de Educação, 2010.

ARAKI, Felipe Asato. Redesenvolvimento urbano, uma proposta para a requalificação de antigas áreas industriais na Moóca e no Ipiranga. 2009. In Revista Eletrônica de Arquitetura e Urbanismo. Faculdade de Arquitetura e Urbanismo da Universidade de São Paulo, São Paulo, 2010. P. 186-218. Disponível em: http://www.usjt.br/arq.urb/numero_03/13arqurb3-felipe.pdf. Acesso em: 26 de jun. 2015.

ATHIAS, Renato Monteiro. Núcleo de Estudos e Pesquisas sobre Etnicidade - 2003. Disponível em: http://www.dcs.ufpe.br/nepe. Acesso em: 11 de Jul. 2016.

Povos Indígenas de Pernambuco - Identidade, Diversidade e Conflito. 1. ed. Recife: Editora da UFPE, 2007. v.1. 243p. Disponível em: https://books.google.com.br/books?hl=pt-

BR\&id=miIsAAAAYAAJ\&dq=renato+athias\&focus=searchwithinvolume \&q=real+par que. Acesso em: 28 de jun. 2015.

BAUMAN, Zygmunt. Comunidade: a busca por segurança no mundo atual. Rio de Janeiro. Ed. Jorge Zahar. 2003.

. Confiança e medo na cidade. Rio de Janeiro: Zahar, 2009.

Modernidade líquida. Rio de Janeiro: Zahar, 2001. 
BONDUKI, Nabil Georges. O modelo de desenvolvimento urbano de São Paulo precisa ser revertido. Estudos Avançados (USP Impresso), v. 25, p. 23-36, 2011.

BORTOLOZZI, Arlêude (Org.). Cidades reivindicadas: territórios das lutas urbanas, das utopias e do prazer. São Paulo: Olho d'água, 2011.

BRASIL. Constituição da República Federativa do Brasil de 1988. Brasília. Disponível em: http://www.planalto.gov.br/ccivil_03/constituicao/constituicao.htm. Acesso em: 02 de ago. 2015.

BRITO, Fausto. Expansão Urbana nas grandes metrópoles, o significado da migração intrametropolitana e da mobilidade pendular na reprodução da pobreza. São Paulo em Perspectiva, v. 19, p. 77-83, 2005.

O deslocamento da população brasileira para as metrópoles. Estudos Avançados, v. 57, p. 221-236, 2006.

BUTTIMER, Anna. Aprendendo o dinamismo do mundo vivido. In: CHRISTOFOLLETI, Antônio. Perspectiva da Geografia. São Paulo: Difel, 1982.

CARDOSO, Adauto Lucio. Desigualdades urbanas e políticas habitacionais. Disponível em: http://www.observatoriodasmetropoles.ufrj.br/download/adauto_desig_urb_polhab.pdf. Acesso em: 17 de jan. 2017.

CARlos, Ana Fani Alessandri. A metrópole de São Paulo no contexto da urbanização contemporânea. Estudos avançados. São Paulo, 2009.

A (re)produção do espaço urbano. 2. Ed. São Paulo: Editora da Universidade de São Paulo, 2008.

O lugar no/do mundo. São Paulo: Hucitec, 1996.

CARRANO, Paulo. O conceito de identidade. 2008. Disponível em: http://geografianovest.blogspot.com.br/2008/11/o-conceito-de-identidade.html. Acesso em: 12 de out. 2016. 
CASTELlS, Manuel; BORJA, Jorge. As cidades como atores políticos. Novos Estudos CEBRAP, No 45, julho 1996, PP. 152-166.

CASTELLS, Manuel. O poder da identidade. São Paulo - Paz e Terra, 2000.

CASTRO, Luiz Guilherme Rivera de. Operações urbanas em são Paulo: interesse público ou construção especulativa do lugar. São Paulo: Tese (Doutorado em Estruturas Ambientais Urbanas) - Faculdade de Arquitetura e Urbanismo, Universidade de São Paulo, São Paulo. 2006.

CEM - CENTRO DE ESTUDOS DA METRÓPOLE/FUNDAP - FUNDAÇÃO DE DESENVOLVIMENTO ADMINISTRATIVO. Diagnóstico dos assentamentos precários nos municípios da Macrometrópole Paulista. Base de dados. 2013. Disponível em: http://www.fflch.usp.br/centrodametropole/upload/aaa/654Relatorio\%20II_Assentamentos_Fundap_final_logo.pdf. Acesso em: 14 de jul. 2015.

COSTA, Heloisa Soares de Moura. Desenvolvimento urbano sustentável: uma contradição de termos? R. B. Estudos Urbanos e Regionais, nº 2, março 2000.

CUTTER, Susan L. A ciência da vulnerabilidade: modelos, métodos e indicadores. Revista Crítica de Ciências Sociais, 93 | 2011, 59-69.

DARDEL, Eric. O homem e a terra: natureza da realidade geográfica. Perspectiva. São Paulo, 2011.

DAVIS, Mike. Planeta favela. São Paulo, Boitempo, 2006.

DI GIULIO, Gabriela Marques; VASCONCELlOS, Maria Da Penha; GÜNTHER, Wanda Maria Rizzo; RIBEIRO, Helena; ASSUNÇÃO, João Vicente de. Percepção de risco: um campo de interesse para a interface ambiente, saúde e sustentabilidade. Saúde e Sociedade (Online), v. 24, p. 1217-1231, 2015. Disponível em: http://www.scielo.br/scielo.php?script=sci_arttext\&pid=S010412902015000401217\&lng=en\&nrm=iso\&tlng=pt. Acesso em: 18 de jan. 2016.

DI GIULIO, Gabriela Marques; VASCONCELlOS, Maria da Penha; LEMOS, Maria Carmen; RIBEIRO, Wagner Costa. A Megacidade de São Paulo e as Mudanças 
Climáticas: carência e urgência no tempo e espaço em Políticas Públicas Urbanas. In: $7^{\circ}$ Enanppas, 2015, Brasília. $7^{\circ}$ Encontro Nacional da Anppas - Anais, 2015.

DUARTE, Rosália. Entrevistas em pesquisas qualitativas. EDUCAR, Curitiba: Editora UFPR, 2004.

ESCRITÓRIO PAULISTANO ARQUITETURA. Cj. habitacional do real parque| 2012| são paulo, sp. Disponível em: http://www.epaulistano.com.br/real-parquememorial.html. Acesso em: 22 de ago. 2016.

FERREIRA, Maíra Soares. A rima na escola, o verso na história. São Paulo: Biotempo, 2012.

FERREIRA, Luiz Felipe. Iluminando o Lugar: três abordagens (Relph, Buttimer e Harvey). Boletim Goiano de Geografia. Goiânia, jan/julho de 2002. v. 22, n.01. p. 4372.

FLECK, Marcelo Pio de Almeida. Desenvolvimento da versão em português do instrumento de avaliação de qualidade de vida da OMS, 1999. Revista Brasileira de Psiquiatria 21(1): 19-28.

FONSECA, João José Saraiva da. Metodologia da pesquisa científica. Fortaleza: UEC, 2002.

FRANÇA, Vanessa Abdo. Da Aldeia a Favela: Estudo da Identidade de Índios Pankararu no Real Parque. Dissertação de Mestrado. São Paulo: PUC-SP, 2008.

FUNES, Silvia. Regularização Fundiária na Cidade de Piracicaba - SP: Ações e Conflitos. Dissertação apresentada ao Programa de Pós-graduação em Engenharia Urbana da Universidade Federal de São Carlos, São Carlos, 2005.

GARCIA, Fernando; CASTELO, Ana Maria. O déficit habitacional cresce apesar da ampliação do crédito. Conjuntura da Construção, 4(1), 8-11. 2006. Disponível em: http://www.cadernosmetropole.net/download/cm_artigos/cm17_101.pdf. Acesso em: 01 de ago. 2015. 
GERHARDT. Tatiana Engel; SILVEIRA, Denise Tolfo (organizadoras). Métodos de pesquisa. Coordenado pela Universidade Aberta do Brasil - UAB/UFRGS e pelo Curso de Graduação Tecnológica - Planejamento e Gestão para o Desenvolvimento Rural da SEAD/UFRGS. - Porto Alegre: Editora da UFRGS, 2009.

GOMES, Paulo César da Costa. Identidade e exílio: Fundamentos para a compreensão da cultura. In: Espaço e Revista. UFRJ/NEPEC. Número 5, Jan/Jun de 1998.

GONDIM, Sônia Maria Guedes. Grupos focais como técnica de investigação qualitativa: Desafios metodológicos. Universidade Federal da Bahia. Paidéia, 2003.

GUIMARÃES, Berenice Martins. As vilas favelas em Belo Horizonte: o desafio dos números. 2000. In: RIBEIRO, Luiz Cesar de Queiroz (org.). O futuro das metrópoles: desigualdade e governabilidade. Rio de Janeiro, Revan/Fase, 2000. pp. 351-374.

HARVEY, David. Justice, nature and the geography of difference. Blackwell Publishers, 1996.

HEIDEGGER, Martin. Bâtir habiter penser. In: Essays et Conférences, Paris: Gallimard, 1958.

HISSA, Cássio Eduardo Viana; MELO, Adriana Ferreira de. O lugar e a cidade. Conceitos do mundo contemporâneo. In: HISSA, Cássio Eduardo Viana. Saberes ambientais. Belo Horizonte: Editora UFMG, 2008.

HOGAN, Daniel Joseph (Org.). Dinâmica populacional e mudança ambiental: cenários para o desenvolvimento brasileiro. Núcleo de Estudos de População NEPO/UNICAMP, Campinas, 2007.

HOGAN, Daniel Joseph; MARANDOLA JR., Eduardo. Socio-demographic vulnerability to environmental hazards of the metropolis. Source, US, v.11, p.42-48, 2008. 
HOLZ, Sheila; MONTEIRO, Tatiana Villela de Andrade. Política de habitação social e o direito à moradia no Brasil. In: X Coloquio Internacional de Geocrítica, 2008, Barcelona. Actas del X Coloquio Internacional de Geocrítica, 2008.

HOLZER, Werther. O lugar na Geografia Humanista. Revista Território. Rio de Janeiro. Ano IV, $\mathrm{n}^{\circ}$ 7. p.67-78, 1999. Disponível em: http://www.revistaterritorio.com.br/pdf/07_6_holzer.pdf. Acesso em: 12 de out. 2016.

IBGE (1980). Censo Demográfico 1980. Rio de Janeiro, IBGE.

IBGE (1991). Censo Demográfico 1991. Rio de Janeiro, IBGE.

IBGE (2000). Censo Demográfico 2000. Rio de Janeiro, IBGE.

IBGE (2010). Censo Demográfico 2010. Rio de Janeiro, IBGE.

IBGE (2011). Censo Demográfico 2010. Aglomerados Subnormais. Primeiros Resultados. Rio de Janeiro, IBGE.

IBGE - INSTITUTO BRASILEIRO DE GEOGRAFIA E ESTATÍSTICA. Base de dados. Disponível em: http://www.ibge.gov.br. Acesso em: 28 de ago. 2015.

ICE - INSTITUTO DE CIDADANIA EMPRESARIAL. Projeto Casulo. Disponível em: http://ice.org.br/projeto-casulo/. Acesso em: 12 de set. 2016.

INFOCIDADE PREFEITURA DE SÃO PAULO. Habitação - Notas técnicas. 2015. Disponível em: http://infocidade.prefeitura.sp.gov.br/index.php?sub=notas \&cat=9\&titulo=Habita $\% \mathrm{E} 7 \%$ E3o\&subtit=\%20-\%20Notas\%20T\%E9cnicas. Acesso em: 22 de ago. 2016.

INGOLD, Tim; KURTTILA, Terthi. Perceiving the environment in finnish lampland. In: Body \& Society, V.6. Londres: Sage, 2000. 
INGOLD, Tim. The perception of the environment. Essays in Livelihood, Dwelling and Skill. Londres: Routledge, 2000.

JACOBI, Pedro. Dilemas socioambientais na gestão metropolitana: do risco à busca da sustentabilidade urbana. Política \& Trabalho. Revista de Ciências Sociais, v.25, p.115-34, 2006.

KLUTHCOVSKY, Ana Cláudia Garabeli Cavalli; TAKAYANAGUI, Angela Maria Magosso. Qualidade de vida - Aspectos Conceituais. 2007. Disponível em: http://www.observatorionacionaldoidoso.fiocruz.br/biblioteca/_artigos/12.pdf. Acesso em: 12 de out. 2016.

KOMAKECH, Morris D. C.; JACKSON, Suzanne F. A Study of the Role of Small Ethnic Retail Grocery Stores in Urban Renewal in a Social Housing Project, Toronto, Canada. Journal of Urban Health: Bulletin of the New York Academy of Medicine, Vol. 93, No. 3, 2016.

KOWARICK, Lúcio. Escritos urbanos. São Paulo: Editora 34, 2000. Viver em risco. São Paulo: Editora 34, 2009.

LEES, Loretta; BUTLER, Tim; BRIDGE Gary. Introduction: mixed communities and gentrification. 2012. In BRIDGE, Gary; BUTLER, Tim; LEES Loretta (eds.). Mixed communities: gentrification by stealth? Policy Press, Bristol, 2011.

LEITE, Adriana. Lugar: duas acepções geográficas. In: Anuário do Instituto de Geociências. Rio de janeiro: UFRJ, 1998, v. 21. Disponível em: [texto para download] Acesso em: 17 de mai. de 2017.

LEITE, Carlos. Megacidade e redesenvolvimento sustentável: uma estratégia propositiva. Revista Brasileira de Gestão Urbana, vol. 2, no 1, p. 117-126. São Paulo, 2010.

LEMOS, André Luiz Martins. Cultura da Mobilidade. Revista FAMECOS (Online), v. 1, p. 28-35, 2009. 
LENCIONI, Sandra. Uma nova determinação do urbano: o desenvolvimento do processo de metropolização do espaço. In: CARLOS, Ana Fani Alessandri; LEMOS, Amália Inês Geraiges (orgs.). Dilemas urbanos: novas abordagens sobre a cidade. São Paulo, Contexto, 2003.

LESTINGE, Sandra Regina. Olhares de educadores ambientais para estudo do meio e pertencimento. 2004. Dissertação (Doutorado em Recursos Florestais). Escola Superior de Agricultura “Luiz de Queiroz”, Universidade de São Paulo, Piracicaba.

LOBO, Maria da Silveira. Aprendendo com o Regent Park. 2011. Disponivel em: http://www.pou.vitruvius.com.br/revistas/read/minhacidade/12.133/4004. Acesso em: 10 de mai. 2017.

MACHOSIKI, Flávio. Uso do programa Google Earth na Produção do conhecimento. Educação Ambiental. Trabalho de conclusão de curso, Universidade Federal do Paraná. Matinhos, Paraná, 2015.

MAFFESOLI, Michel. Du nomadism. Vagabondages Initiatiques. Paris: Librarie Générale Française, 1997.

MARANDOLA JR., Eduardo. Habitar em Risco: mobilidade e vulnerabilidade na experiência metropolitana. 278f. Tese (Doutorado em Geografia) - Instituto de Geociências, Universidade Estadual de Campinas, Campinas, 2008.

Tangenciando a vulnerabilidade. In HOGAN, Daniel Joseph; MARANDOLA JR. Eduardo (orgs). População e mudança climática: dimensões humanas das mudanças ambientais globais. Campinas: NEPO/UNICAMP; Brasília: UNFPA, 2009. p. 29-52.

MARANDOLA JR., Eduardo; D'ANTONNA, Álvaro de Oliveira; OJIMA, Ricardo (Orgs.). População, ambiente e desenvolvimento: mudanças climáticas e urbanização no Centro-Oeste. Campinas: NEPO/UNICAMP, 2011.

MARICATO, Erminia. Brasil, cidades: Alternativas para a crise urbana. 7 Ed. Petrópolis, RJ: Vozes, 2013. 
MARQUES, César; FREY, Henrique. As mudanças habitacionais em regiões metropolitanas brasileiras. Urbe. Revista Brasileira de Gestão Urbana, v. 7, p. 250267, 2015. Disponível em: http://www.scielo.br/pdf/urbe/v7n2/2175-3369-urbe-7-2250.pdf. Acesso em: 02 de jun. 2015.

MELLO, Edimeia Maria Ribeiro de. Desenvolvimento sustentável e gestão das cidades. Tecer (Belo Horizonte), v. 3, p. 96-107, 2010.

MENDES, José Manuel; TAVARES, Alexandre Oliveira. Risco, vulnerabilidade social e cidadania. Revista Crítica de Ciências Sociais, 2011. Disponível em http://rccs.revues.org/173. Acesso em: 30 de jul. 2015.

MENDES, José Manuel; TAVARES, Alexandre Oliveira; CUNHA, Lúcio; FREIRIA, Susana. A vulnerabilidade social aos perigos naturais e tecnológicos em Portugal. Revista Crítica de Ciências Sociais, 93|2011. 95-128. Diponível em: http://www.ces.uc.pt/myces/UserFiles/livros/1097_rccs-90-93-a-vulnerabilidade-socialaos-perigos-naturais-e-tecnologicos-em-portugal.pdf. Acesso em: 03 de ago. 2015.

MINAYO, Maria Cecília de Souza (Org.). Pesquisa social: teoria, método e criatividade. Petrópolis: Vozes, 2001.

MIRANDOLA, Fabricio Araujo. Zoneamento de risco geológico na área da favela Real Parque, São Paulo. Monografia (Trabalho de Formatura). 120p. Graduação em Geologia, Instituto de Geociências, Universidade de São Paulo, 2003.

MORGAN, David L. Focus group as qualitative research. Qualitative Research Methods Series. 16. London: Sage Publications, 1997.

NAKAMURA, Pedro Kiyoshi Camargo. O social verticaliza a cidade. Dissertação de Mestrado em Arquitetura e Urbanismo. FAU, USP, 2016

OLIVEIRA, Ana Carmen. "Você sabe o que é apatia social?". 2013. Disponível em: http://www.educadoresonline.com.br/fique-por-dentro/psicologia-e-educacao/vocesabe-o-que-e-apatia-social. Acesso em: 10 de mai. 2017. 
ONU - ORGANIZAÇÃO DAS NAÇÕES UNIDAS. Propostas Rio + 20. Fatos sobre as cidades. 2012. Disponível em: http://www.onu.org.br/rio20/cidades.pdf. Acesso em: 16 de nov. 2015.

OSÓRIO, Letícia Marques. Direito à moradia adequada na América Latina. In ALFONSIN, Betânia de Moraes. FERNANDES, Edésio. Direito à moradia e segurança da posse no Estatuto da Cidade: diretrizes, instrumentos e processos de gestão. Belo Horizonte: Fórum, 2004.

PADILHA, Bruno da Graça Leite. Organização comunitária em rede: Um Estudo de Integração e Fortalecimento Associativo da Favela do Real Parque. (Dissertação de Mestrado). São Paulo: PUC-SP, 2006.

PARAGUAI, Luisa. Narrativas imagéticas na Web: leituras e construções hipertextuais. Doc On-Line: revista digital de cinema documentario, v. 05, p. 24-35, 2008 .

PASTERNAK, Suzana; D'OTTAVIANO, Camila. Favelas no Brasil e em São Paulo: avanços nas análises a partir da Leitura teritorial do Censo de 2010. Cadernos Metrópole (PUCSP), v. 18, p. 75-99, 2016.

POCOCK, Douglas Charles David. Place and the novelist. Transactions of the lnstitute of British Geographers N. S., (6), pp. 337-347, 1981.

PREFEITURA DA CIDADE DE SÃO PAULO/DIAGONAL URBANA/SEHAB. Relatório síntese de caracterização. 2008.

PREFEITURA DE SÃO PAUlO. Gestão Urbana - São Paulo tem um plano. Disponível em: http://gestaourbana.prefeitura.sp.gov.br/entenda-a-lei/ Acesso em: 27 de out. 2015.

. Plano Diretor Estratégico do Município de São Paulo. Disponível em: www.prefeitura.sp.gov.br/cidade/secretarias/.../plano_diretor/index.php. Acesso em: 20 de out. 2015. 
. Sehab inicia obras dos 1.135 apartamentos da urbanização do Real Parque.

Disponível

em:

http://www.prefeitura.sp.gov.br/cidade/secretarias/habitacao/noticias/?p=22249. Acesso em: 29 de ago. 2015.

PRINCE, Hugh C. The geographical imagination. Landscape, 11 (1), pp. 22-25, 1961.

PROJETO CASULO. Perfil dos jovens das comunidades do Real Parque e Jardim Panorama.

Disponível

em:

http://www.projetocasulo.org.br/download/Pesquisa_Jovens_Real_e_Panorama-

ppt_Modo_de_Compatibilidade.pdf. Acesso em: 13 de ago. 2015.

QADEER, Mohammad. A. Segregação étnica em uma cidade multicultural, Toronto, Canadá. Revista Espaço \& Debates, v. 24, n. 45, jan-jul. São Paulo, 2004, NERU.

REZENDE, Heloisa Diniz de. Forma. Reforma. Desforma: o novo formato da política pública para favelas. Dissertação de Mestrado, FAU/USP. São Paulo, 2015.

RIBEIRO, Wagner Costa. Riscos e vulnerabilidade urbana no Brasil. Scripta Nova (Barcelona), 2010.

ROLNIK, Raquel; KLINK, Jeroen. Crescimento econômico e desenvolvimento urbano: por que nossas cidades continuam tão precárias? Novos estud. - CEBRAP [online]. 2011, n.89 pp. 89-109. Disponível em: http://www.scielo.br/scielo.php?script=sci_arttext\&pid=S0101-

$33002011000100006 \& \operatorname{lng}=$ pt\&nrm=iso\&tlng=pt. Acesso em: 15 de dez. 2015.

ROSE, Damaris; GERMAIN, Annick; BACQUÉ, Marie-Hélène; BRIDGE, Gary; FIJALKOW, Yankel; SLATER, Tom. "Social Mix" and Neighbourhood Revitalization in a Transatlantic Perspective: Comparing Local Policy Discourses and Expectations in Paris (France), Bristol (UK) and Montréal (Canada). International Journal of Urban and Regional Research, 2013. 
ROSO, Mafalda; OLIVEIRA, Andréia Machado; MIRANDA, Roxane Leandra dos Santos. Construção de narrativas imagéticas digitais. In: ANPAP, 2009, Salvador. ANPAP. Salvador, 2009.

SACONI, Rose; ENTINI, Carlos Eduardo. Acervo Estadão - Como era São Paulo sem Plano Diretor. Disponível em: http://acervo.estadao.com.br/noticias/acervo,comoera-sao-paulo-sem-plano-diretor,9276,0.htm. Acesso em: 26 de out. 2015.

SALVAGNI, Julice; SILVEIRA, Marco Antônio Negri da. Discursos imagéticos: a fotografia como método da pesquisa social. In: II Encontro História, Imagem e Cultura Visual, 2013, Porto Alegre. Grupo de Trabalho da Associação Nacional de História-Seção Rio Grande do Sul/ANPUH-RS, 2013.

SAMPAIO, Maria Ruth Amaral de; PEREIRA, Paulo Cesar Xavier. Habitação em São Paulo. USP. Estudos Avançados 48, São Paulo, v. 17, n.48, p. 167-183, 2003.

SANTOS, Milton. A natureza do espaço: técnica e tempo, razão e emoção. São Paulo: HUCITEC, 384 p, 1996.

. Espaço e método. São Paulo: Nobel, 120 p, 1997.

Pensando o espaço do homem. São Paulo: HUCITEC, 1982.

Por uma Economia Política da Cidade. São Paulo: HUCITEC/Educ, 1994.

Por uma outra globalização: do pensamento único à consciência universal. 14. Ed. Rio de Janeiro: Record, 2007.

—. Técnica, espaço, tempo: globalização e meio técnico-científicoinformacional. São Paulo: Hucitec, 190 p, 1998.

SANTOS, Milton; SILVEIRA, Maria Laura. O Brasil: território e sociedade no início do século XXI. Editora Record. Rio de Janeiro-São Paulo, 2001.

SARKISSIAN, Wendy. The idea of social mix in town planning: a historical review. Urban Studies 13.3, 231-46, 1976. 
SCARLATO, Francisco Capuano. O espaço industrial brasileiro. In: ROSS, Jurandyr Luciano Sanches. Geografia do Brasil. São Paulo, Edusp, 2005.

População e urbanização brasileira. In: ROSS, Jurandyr Luciano Sanches. Geografia do Brasil. São Paulo, Edusp, 2005.

SEADE - FUNDAÇÃO SISTEMA ESTADUAL DE ANÁliSE DE DADOS. Programa de verticalização de favelas (PROVER). 2016. Disponível em: http://www.seade.gov.br/2016/. Acesso em: 11 de Ago. 2016.

SEHAB - SECRETARIA MUNICIPAL DE HABITAÇÃO/FAU USP. Projeto Real $\begin{array}{llllll}\text { Parque } & - & \text { São } & \text { Paulo. } & \text { 2009. } & \text { Disponível }\end{array}$ http://www.fau.usp.br/arquivos/disciplinas/au/aup0278/2013.2/Real\%20Parque\%20FA U.pdf. Acesso em: 11 de Jul. 2016.

SETO, Karen. et al. The new geography of contemporary urbanization and the environment. Annual Review of Environment and Resources 35 (2010): 167-194, 2010 .

SILVA, Josimey Costa da. Leituras imagéticas e urbanidade em ações culturais nas cidades de Natal e São Paulo: apontamentos sobre proposições comunicacionais. INTERCOM (Congresso), 2006.

_ Narrativa imagética: A ciência com prazer. Disponível em: http://josimeycosta.objectis.net/ensaios/narrativa-imagetica-a-ciencia-com-prazer/view. Acesso em: 10 de mai. 2017.

SINGER, Paul Israel. Economia Política da Urbanização. São Paulo: Brasiliense, 1973.

SPOSATI, Aldaiza (Coord.). Mapa de exclusão/inclusão social da cidade de São Paulo/2000: dinâmica social dos anos 90. São Paulo: Projeto Gráfico e Formatação, 2000. CD-ROM.

SPTRANS - SÃO PAULO TRANSPORTES. Itinerários de ônibus. Disponível em: http://www.sptrans.com.br/itinerarios/.Acesso em: 15 de Mai. 2017. 
STEIL, Carlos Alberto; CARVALHO, Isabel Cristina de Moura (orgs). Cultura, percepção e ambiente: Diálogo com Tim Ingold. Editora Terceiro Nome. São Paulo, 2012.

TARTUCE, T. J. A. Métodos de pesquisa. Fortaleza: UNICE - Ensino Superior, 2006.

TORONTO COMMUNITY HOUSING. Regent Park - Social development plan. 2007. Disponível em: http://www.toronto.ca/legdocs/mmis/2007/ex/bgrd/backgroundfile-7300.pdf. Acesso em: 10 de mai. 2017

TUAN, Yi-Fu. Space and place: humanistic perspective. In: GALE, S. OLSSON, G. (orgs.). Philosophy in Geography. Dordrecht: Reidel, 1979, pp. 387-427. (Publicado originalmente em: Progress in Geography, (6), pp. 211-252, 1974).

VALENTIM, Luís Sérgio Ozório. Requalificação urbana em áreas de risco à saúde devido à contaminação do solo por substâncias perigosas: um estudo de caso na cidade de São Paulo. São Paulo, 2005.

Sobre a produção de bens e males nas cidades: estrutura urbana e cenários de risco à saúde em áreas contaminadas da metrópole paulista. São Paulo, Annablume; FAPESP, 2013.

VEIGA, Luciana; GONDIM, Sônia Maria Guedes. A utilização de métodos qualitativos na ciência política e no marketing político. Opinião Pública. 2(1), 1-15, 2001.

VEYRET, Yvette. Os riscos: o homem como agressor e vítima do meio ambiente. São Paulo: Contexto, 2007.

WISNER, Ben; BLAIKIE, Piers; CANNON, Terry; DAVIS, Ian. At Risk - Natural hazards, people's vulnerability and disasters. Londres: Routledge, 2004. 